Navigation Span Location Study for Greenville Bridge Reach, Mississippi River

Donald C. Wilson

September 2000

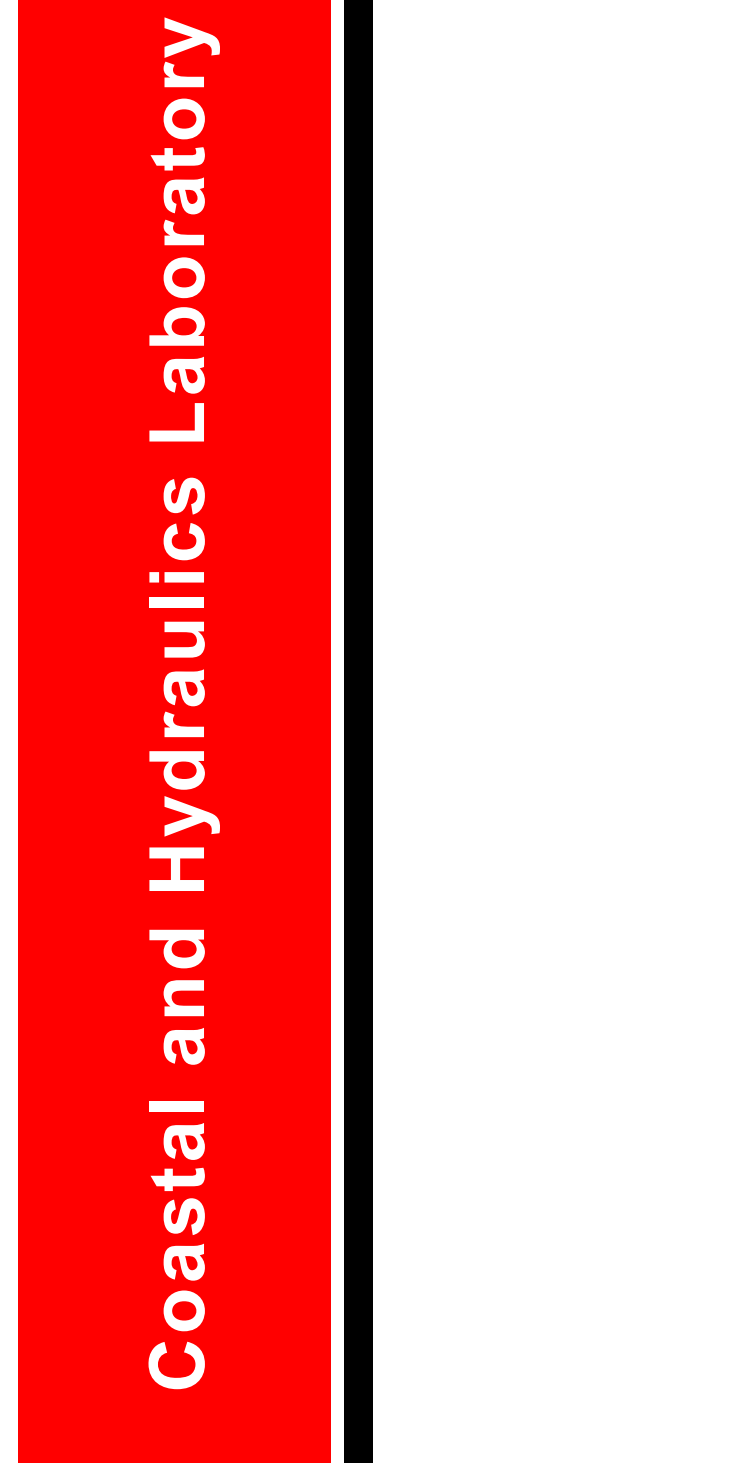

US Army Corps of Engineers ${ }_{\circledast}$

Engineer Research and Development Center

Approved for public release; distribution is unlimited. 
The contents of this report are not to be used for advertising, publication, or promotional purposes. Citation of trade names does not constitute an official endorsement or approval of the use of such commercial products.

The findings of this report are not to be construed as an official Department of the Army position, unless so designated by other authorized documents. 


\section{Navigation Span Location Study for Greenville Bridge Reach, Mississippi River}

by Donald C. Wilson

Coastal and Hydraulics Laboratory

U.S. Army Engineer Research and Development Center 3909 Halls Ferry Road

Vicksburg, MS 39180-6199

Final report

Approved for public release; distribution is unlimited 


\section{Engineer Research and Development Center Cataloging-in-Publication Data}

Wilson, Donald C.

Navigation span location study for Greenville bridge reach, Mississippi River / by Donald C. Wilson ; prepared for U.S. Army Engineer District, Vicksburg.

78 p. : ill. ; $28 \mathrm{~cm}$.-- (ERDC/CHL ; TR-00-20)

Includes bibliographic references.

1. Navigation -- Mississippi River -- Models. 2. Mississippi River -- Navigation. 3. Bridges -- Mississippi. 4. Highway 82 Bridge (Ark. And Miss.) I. United States. Army. Corps of Engineers. Vicksburg District.

II. Engineer Research and Development Center (U.S.) III. Coastal and Hydraulics Laboratory (U.S.) IV. Title. V. Series: ERDC/CHL TR ; 00-20.

TA7 E8 no.ERDC/CHL TR-00-20 


\section{Contents}

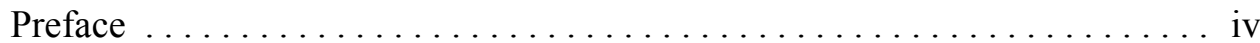

Conversion Factors, Non-SI to SI Units of Measurement $\ldots \ldots \ldots \ldots \ldots \ldots$ v

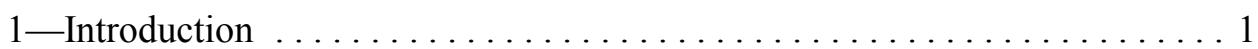

Location and Description of the Prototype $\ldots \ldots \ldots \ldots \ldots \ldots \ldots$

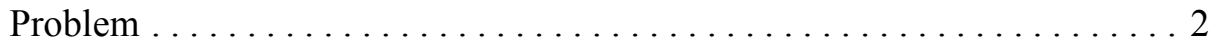

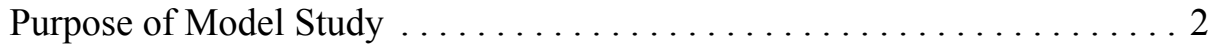

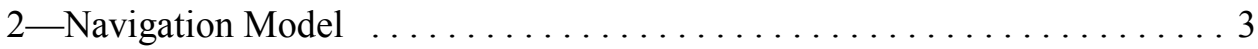

History of Navigation Model Study $\ldots \ldots \ldots \ldots \ldots \ldots \ldots \ldots \ldots$

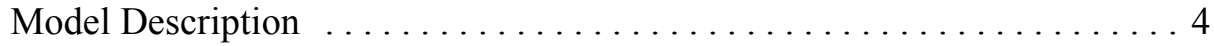

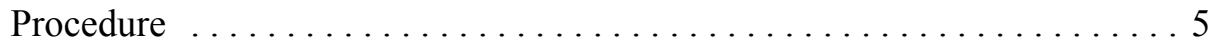

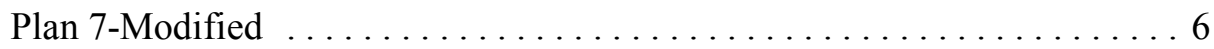

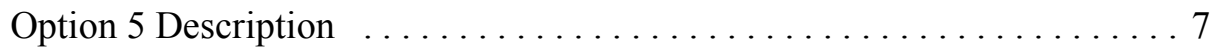

Meter Velocities .............................. 7

$3-$ Recommendations and Conclusions $\ldots \ldots \ldots \ldots \ldots \ldots$

Figures 1-3

Photos 1-8

Plates 1-53

SF 298 


\section{Preface}

The model investigation herein was performed by the former Hydraulics Laboratory (HL), U.S. Army Engineer Waterways Experiment Station (WES), Vicksburg, MS, for the U.S. Army Engineer District, Vicksburg. The study was conducted in HL during the period March 1996 to August 1996.

During the course of the model study, representatives of the towing industry, Mississippi Department of Transportation, and other navigation interests visited WES at different times to observe special model experiments and to discuss the experiment results. The Vicksburg District was kept informed of the progress of the study through monthly progress reports and special briefings at the end of each phase.

This investigation was conducted under the general supervision of Messrs. F. A. Herrmann, Jr. (retired), Director of HL, and R. A. Sager (retired), Assistant Director of HL. It was conducted under the direct supervision of Dr. L. L. Daggett (retired), Chief, Waterways Division, HL. The Principal Investigator of the model study was Mr. Donald C. Wilson, assisted by Messrs. B. T. Crawford and Keith Green and Ms. Debbie George, Navigation Division, HL.

This report was published by the U.S. Army Engineer Research and Development Center (ERDC) Coastal and Hydraulics Laboratory (CHL). CHL was formed in October 1996 with the merger of the Coastal Engineering Research Center and the Hydraulics Laboratory.

Mr. Thomas W. Richardson was the Acting Director of CHL; Mr. Thomas J. Pokrefke, Jr., was Acting Assistant Director of CHL; and Mr. C. E. Chatham was Chief of the Navigation and Harbors Division of CHL.

At the time of publication of this report, Director of ERDC was Dr. James R. Houston; Commander of ERDC was COL James S. Weller, EN.

The contents of this report are not to be used for advertising, publication, or promotional purposes. Citation of trade names does not constitute an official endorsement or approval of the use of such commercial products. 


\section{Conversion Factors, Non-SI to SI Units of Measurement}

Non-SI units of measurement used in this report can be converted to SI units as follows:

\begin{tabular}{||l|l|l|}
\hline \hline Multiply & By & To Obtain \\
\hline \hline cubic feet & 0.02831685 & cubic meters \\
\hline feet & 0.3048 & meters \\
\hline miles (U.S. statute) & 1.609347 & kilometers \\
\hline
\end{tabular}




\section{Introduction}

\section{Location and Description of the Prototype}

The Greenville Bridge Reach of the Mississippi River affects navigation conditions for tows navigating through the Greenville Bridge located at Mile 531.3 about 12 miles $^{1}$ downstream of Greenville, MS (Figure 1). The bridge was completed in 1940 and includes the following: a navigation span that has a clear width of $800 \mathrm{ft}$ near the center of the narrow channel; two river spans, one on each side of the navigation span; and extensive embankments forming the approach on each side.

When the bridge was completed, the channel followed the right bank on the Arkansas side of the river from just above Vaucluse revetment (Mile 535.0) to the bridge, providing a long straight approach upstream of the bridge. In 1942, the channel through Leland cutoff began to shift, affecting channel alignment upstream and downstream of the bridge. By 1949, the channel at the upper end of Island 84 (Mile 537) had migrated from the right bank toward the left bank assisted by dredging in the chute channel along the left bank and depositing the dredge material in the channel to the right.

The reach is downstream of a series of cutoffs and has been somewhat unstable, with a tendency to cross back toward the right bank farther upstream. However, with the construction of the Island 84 dikes in 1967 and 1968 and some dredging, the channel developed and maintained its present alignment along the left bank before crossing toward the right bank a short distance upstream of the bridge. The channel at the bridge has an average width of about $2,400 \mathrm{ft}$ and is narrow in comparison with the channel upstream and downstream. Velocities in the reach tend to be high and very turbulent. Conditions are aggravated by the formation and movement of the sandbar along the downstream end of Island 84 close to the bridge.

1 A table of factors for converting non-SI units of measurement to SI units is presented on page v. 


\section{Problem}

Navigation conditions through the Greenville Bridge are difficult and hazardous, particularly with the channel shifting from the right to the left side, upstream of Island 84 . Conditions at the bridge are affected by the limited straight approach distance and the velocity and alignment of the currents upstream of the bridge. In March 1948, the towboat Natchez hit one of the bridge piers and capsized with considerable loss of life. This tragedy focused attention on these navigation problems and intensified efforts to develop remedial measures.

\section{Purpose of Model Study}

Several plans were proposed to improve navigation conditions at the bridge. However, because of the many factors involved in the development of the reach and the complex nature of alluvial streams, analytical evaluation of the proposed plans' effects are extremely difficult and inconclusive. Therefore, physical hydraulic model studies were necessary to measure the proposed plans' effect on stability, maintenance, and navigation in the reach. 


\section{Navigation Model}

\section{History of Navigation Model Study}

A semi-fixed bed navigation model of the Greenville Bridge Reach was constructed in 1979 to evaluate proposed improvements to the reach. The model reproduced approximately 4 miles of the Mississippi River from river mile 530.5 to river mile 534.5. Base data were collected with the model reproducing a June 1979 hydrographic survey so the proposed improvements could be compared to the base conditions. After base data were collected, data were collected and navigation conditions evaluated with five proposed plans.

Plan 4-A (Figure 2) was selected as the plan with the most satisfactory navigation conditions. The Potomology Branch, Waterways Division, Hydraulics Laboratory, U.S. Army Engineer Waterways Experiment Station (WES), Vicksburg, MS, investigated this plan in a moveable-bed model of Greenville Bridge Reach. Extensive experiments with the movable-bed model indicated that Plan 4-A was not stable as designed. Consequently, the Potomology Branch stabilized the river in a configuration very similar to Plan 4-A and gave this new plan, named Plan 6 (Figure 3), to the Navigation Branch for evaluation of navigation conditions. Because of concerns about the crossing upstream of Island 84 , it was necessary to rebuild the navigation model to recreate more of the river upstream of Island 84 . Therefore, the model was rebuilt using the latest hydrographic survey from the U.S. Army Engineer District, Vicksburg (February 1988), to recreate the Mississippi River from River Miles 529.2 to 537.5. Base experiments, conducted with the conditions existing in February 1988, gave data with representative flows, which provided the basis for determining the effects of proposed changes on current alignment and velocities and on navigation conditions through the reach. Navigation conditions with Plan 6 were unsatisfactory with all flows tested because of the formation of a large point bar at Island 84 . The point bar constricted the navigation channel significantly when the river discharge was less than 750,000 cfs. Therefore, the moveable-bed model was reactivated to develop river-training structures to manage the sediment in the reach more efficiently.

Experiments were conducted with several plans using conventional training structures and bendway weirs (submerged dikes angled upstream) and then optimized until a satisfactory channel was maintained. This plan (designated 
Plan 7) was installed in the navigation model, and experiments were conducted. Navigation conditions improved greatly with Plan 7, but the bendway weirs tended to move the model tow too far toward the left of the navigation span. To correct this, the alignment of two weirs was changed slightly. This new plan (designated Plan 7-modified) produced good channel alignment and satisfactory navigation conditions with all flows tested. Therefore, this plan was recommended to the District for construction.

The District began construction of the proposed plan; then the Mississippi Department of Transportation (MDOT) notified the District that it was proposing a new U.S. Highway 82 bridge at Greenville. After reviewing the proposed plans for the bridge, the decision was made to use the existing navigation model to evaluate and document navigation conditions through the proposed bridge with Plan 7-modified channel conditions in the model.

\section{Model Description}

The semifixed bed model of Greenville Bridge Reach duplicates 8.3 miles of the Mississippi River from River Mile 529.2 Above Head of Passes (AHP) to River Mile 537.5 AHP. Overbank areas and the model channel were molded in sand, which allowed for the necessary modifications to improve current alignment and navigation conditions; the bridge was fabricated of sheet metal and plexiglass.

The model was built to an undistorted linear scale ratio of 1:150, model to prototype, to obtain accurate reproduction of velocities, cross currents, and eddies that would affect navigation. Other scale ratios resulting from the linear scale ratio are as follows:

\begin{tabular}{||l|l||}
\hline Area & $1: 22,500$ \\
\hline Velocity & $1: 12.25$ \\
\hline Time & $1: 12.25$ \\
\hline Discharge & $1: 275,567.6$ \\
\hline Roughness (Manning's n) & $1: 2.31$ \\
\hline
\end{tabular}

Measurements of discharges, water-surface elevations, and current velocities can be transferred quantitatively from model to prototype equivalents by means of these scale relations. 


\section{Procedure}

Experiments were concerned primarily with the study of flow patterns, measurement of velocities, and the effects of currents on the navigability of the model tow through the reach with the proposed U.S. Highway 82 bridge installed.

Experiments were conducted by reproducing the following stages and discharges based on stage-discharge relationships furnished by the Vicksburg District:

a. Riverflow of $185,000 \mathrm{cfs}$ with 0 -ft stage. ${ }^{1}$

b. Riverflow of $395,000 \mathrm{cfs}$ with $11-\mathrm{ft}$ stage.

c. Riverflow of $750,000 \mathrm{cfs}$ with $23-\mathrm{ft}$ stage.

d. Riverflow of $1,025,000 \mathrm{cfs}$ with $31-\mathrm{ft}$ stage.

e. Riverflow of 1,500,000 cfs with 41-ft stage.

Riverflows were duplicated by introducing the proper discharge at the upper end of the model and adjusting the tailgate until the proper stage was obtained at the bridge. All stages were permitted to stabilize before data were recorded.

Current directions were determined by plotting the path of floats with respect to ranges established for that purpose, and velocities were measured by timing the travel of floats over measured distances. In the interest of clarity, in the case of plots of currents in turbulent areas or where eddies or crosscurrents existed, only the main trends are shown.

The effects of currents on a tow moving through the reach were determined by observation of the model tow approaching and passing the bridge in both the upstream and downstream directions. The tow used for these experiments represented thirty-five 195 -ft-long by 35 -ft-wide loaded barges with a $100-\mathrm{ft}$ pusher. The flotilla was five barges wide by seven barges long or an overall size of $175 \mathrm{ft}$ wide by $1,465 \mathrm{ft}$ long loaded to a draft of $9 \mathrm{ft}$.

When the proposal was made to conduct experiments with the new U.S. Highway 82 bridge installed, the model was dormant. Therefore, before any experiments were run, the model was remolded to Plan 7-modified and data were collected and compared to previous Plan 7-modified data, to verify that the model was accurately reproducing conditions previously documented. These data were then used as a base for comparison when the new bridge was installed since these conditions should exist in the field after completion of the realignment project.

\footnotetext{
1 Gauge reading at the Greenville Bridge, Greenville, MS.
} 


\section{Plan 7-Modified Description}

Plan 7-modified had a total realignment of the bend upstream of the bridge and major modifications to the dike structures in the reach. The principal features of the plan, shown in Plate 1, include the following:

a. The right-descending bank of the bend upstream of the bridge was excavated to form a long smooth curve. The upstream end of the curve had a radius of 7,000 ft and transitioned into a 9,000-ft radius.

b. Leland Bar Vane Dikes 4-c, 4-d, and 4-e were removed.

c. Warfield Point Dikes 1, 2, and 3 were constructed.

d. Island 84 Dikes 1 and 2 were extended.

$e$. The bed configuration and bendway weir field developed in the movablebed model was installed. The weirs were placed in the navigation channel of the bend with top elevations of -18 LWRP, spaced 1,800 ft apart, and all but the two most downstream weirs were angled $20 \mathrm{deg}$ upstream. The most downstream weir was constructed normal to the bank, and the next one upstream was angled $10 \mathrm{deg}$.

\section{Current direction and velocities}

Current direction and velocity data are shown in Plates 2-6. Velocities in the navigation span of the bridge ranged from a maximum of $2.7 \mathrm{fps}$ with the 185,000 -cfs flow to a maximum of $9.7 \mathrm{fps}$ with a discharge of $1,500,000 \mathrm{cfs}$. When the discharge was below 750,000 cfs, higher velocities were found on the left side of the navigation span; when the discharge was above 750,000 cfs, the higher velocities occurred on the right side of the navigation span.

\section{Navigation conditions}

Tow tracks of the model tow navigating the reach with Plan 7-modified are shown in Plates 7-26. The first plate for each condition consists of a single tow track and represents a normal transit through the reach for that condition. The next plate for each condition shows multiple tow tracks. These plates were included to illustrate the repeatability of multiple experiments with the same river conditions. During all navigation experiments, the model tow was operated to represent a minimal powered towboat. This was accomplished by using just enough thrust in the upbound direction to make headway and in the downbound direction using enough thrust to drive approximately 2 to $3 \mathrm{mph}$ greater than the current speed. Navigation conditions are satisfactory for all flows tested. Upbound tows are able to safely navigate through the reach provided sufficient power is available (Plates 7-16). Downbound tows are able to drive the bend upstream of the bridge and align themselves with the navigation span of the 
bridge sufficiently far upstream to make passage through the bridge safely (Plates 17-26).

\section{Option 5 Description}

MDOT option 5 was the same as Plan 7-modified except the U.S. Highway 82 bridge was removed and the proposed U.S. Highway 82 bridge was installed. The new bridge was located $2,780 \mathrm{ft}$ downstream of the existing bridge and has a 1,378-ft-wide navigation span.

\section{Current direction and velocities}

Current direction and velocity data were not retaken for this condition because the installation of the new bridge had no significant impact on the general flow patterns in the reach.

\section{Navigation conditions}

Navigation conditions were improved as compared with Plan 7-modified (Plates 27-48 and Photos 1-8). Upbound tows were able to navigate the reach without difficulty provided sufficient power was available (Plates 26-36 and Photos 1-4). Downbound tows were able to drive the bend upstream of the bridge and align themselves with the navigation span two to three tow lengths upstream of the bridge (Plates 37-46 and Photos 5-8). With 1,025,000- and $1,500,000$-cfs riverflows, there was a tendency for the tow to be moved toward the right pier of the navigation span (Plates 43-46 and Photos 7-8). This tendency was not severe, and the tow was never in danger of striking the pier. However, the model indicated that the navigation span was not used to its fullest potential. The model tow always passed through the center or right side of the navigation span. Therefore, moving the navigation span $150 \mathrm{ft}$ toward the rightdescending bank is recommended. Plates 47 and 48 are composite tow tracks that show all navigation experiments for upbound and downbound conditions, respectively. On these plates, the proposed U.S. Highway 82 bridge has been moved $150 \mathrm{ft}$ to the recommended location.

\section{Meter Velocities}

Two-dimensional point velocities were taken in the vicinity of the navigation span bridge piers to aid in predicting scour (Plates 49-53). The velocities were taken near the river bottom with a miniature velocity probe. The velocities near the right-descending pier ranged from 1.6 fps with a 185,000-cfs riverflow to 8.5 fps with a 1,500,000-cfs discharge. Velocities near the left-descending pier ranged from less than 0.5 fps with the 185,000 -cfs riverflow to $4.9 \mathrm{fps}$ with a 1,500,000-cfs riverflow. One should note that these velocities were taken with the model representing conditions expected after the river stabilizes to the 
proposed alignment. Furthermore, if the bridge piers are relocated as recommended, the magnitude and direction of the velocities near the piers could be significantly different. 


\section{Recommendations and Conclusions}

The recommendations and conclusions are as follows:

a. Navigation conditions were satisfactory with all flows tested with Plan 7modified.

b. Navigation conditions are improved with Option 5 as compared with Plan 7-modified. However, with 1,025,000- and 1,500,000-cfs discharges, the model tow tends to be moved toward the right-descending pier of the navigation span.

c. Moving the navigation span $150 \mathrm{ft}$ toward the right-descending bank is recommended to use the wider navigation span to its fullest potential.

d. Navigation conditions through the reach while the proposed bridge is being constructed are expected to be quite different than discussed in this report. This is because the river will be in transition between existing conditions and Plan 7-modified conditions during this time. Additional experiments should be conducted to determine navigation conditions during construction. 


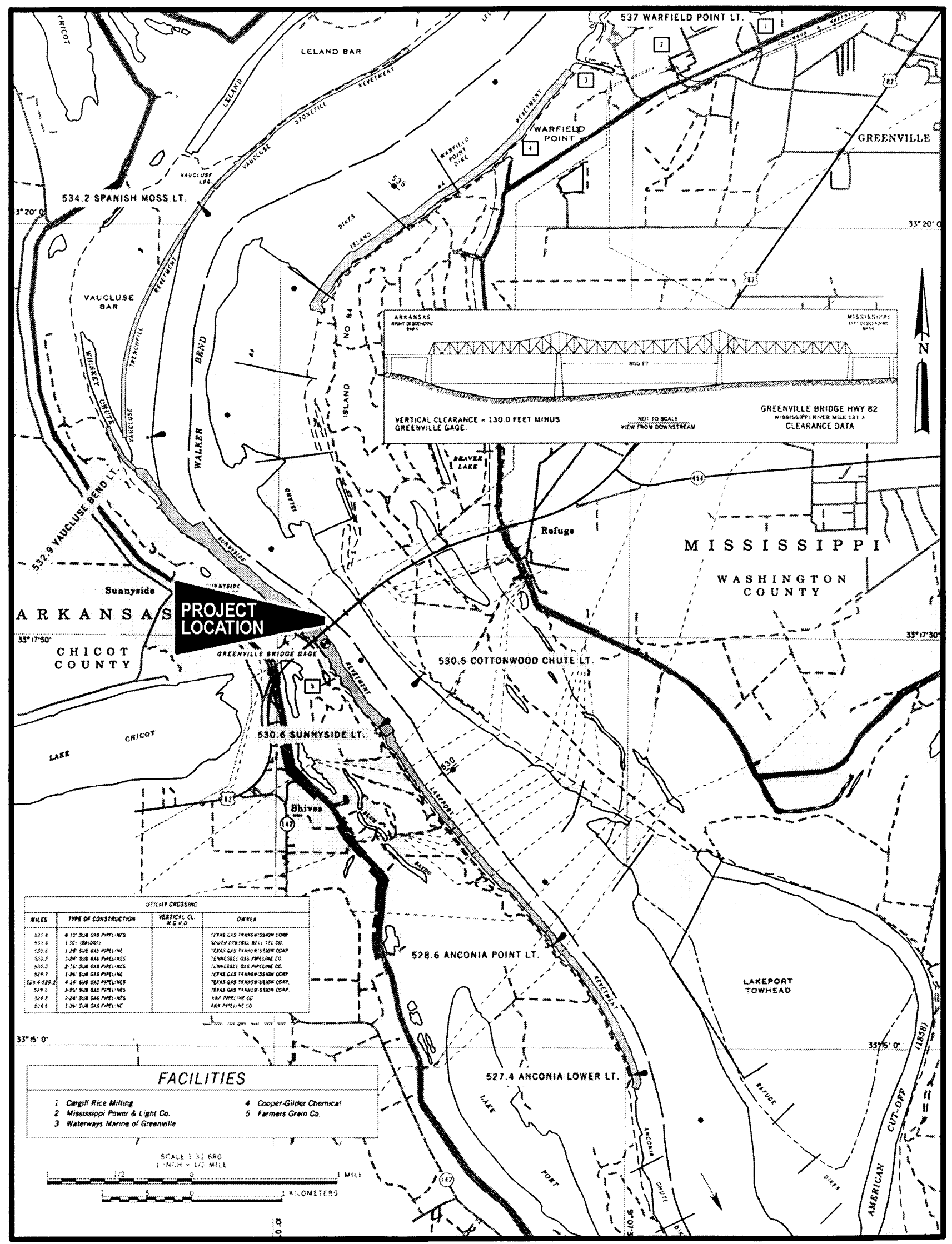

Figure 1. Greenville Bridge - location map 


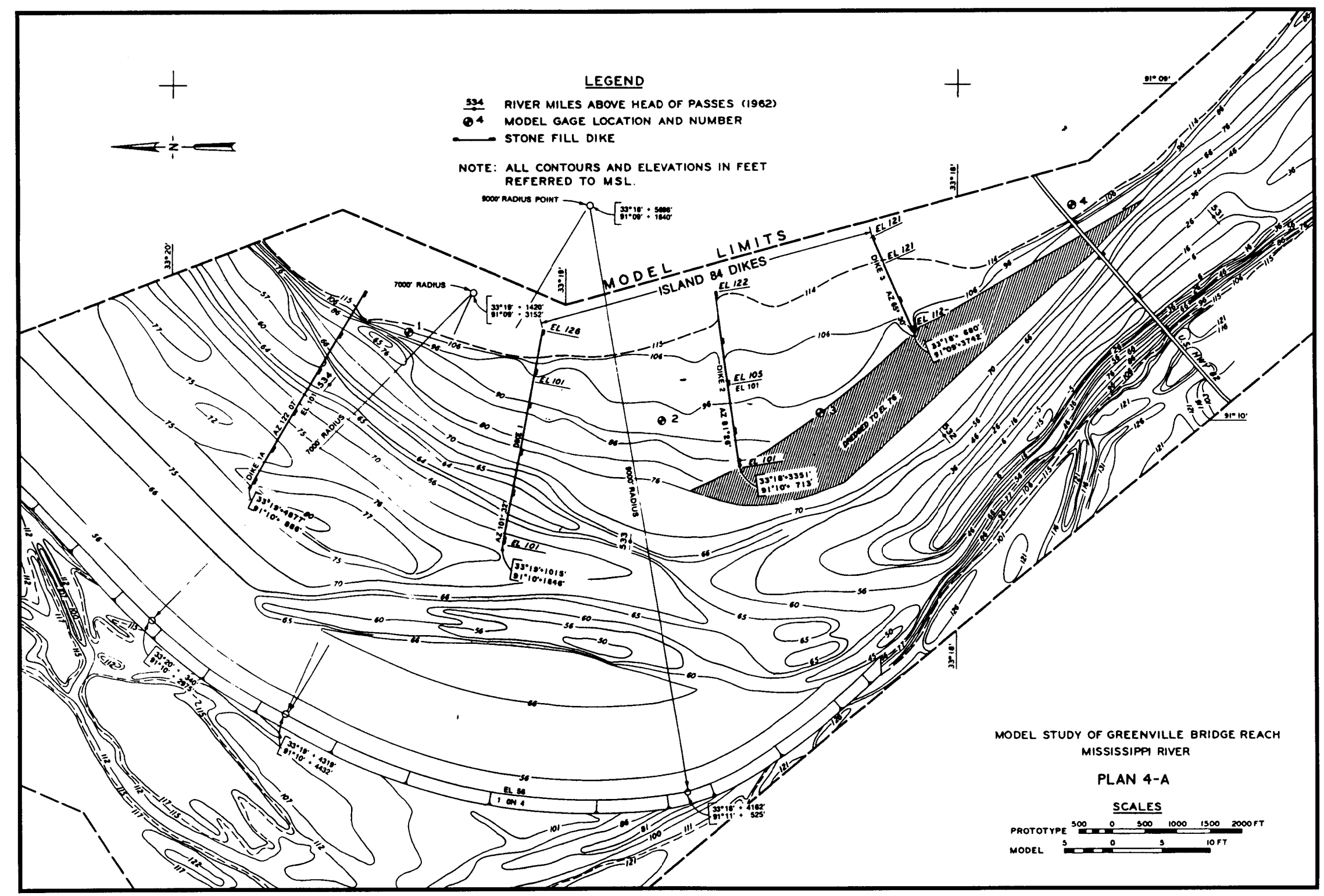

Figure 2. Plan 4-A 


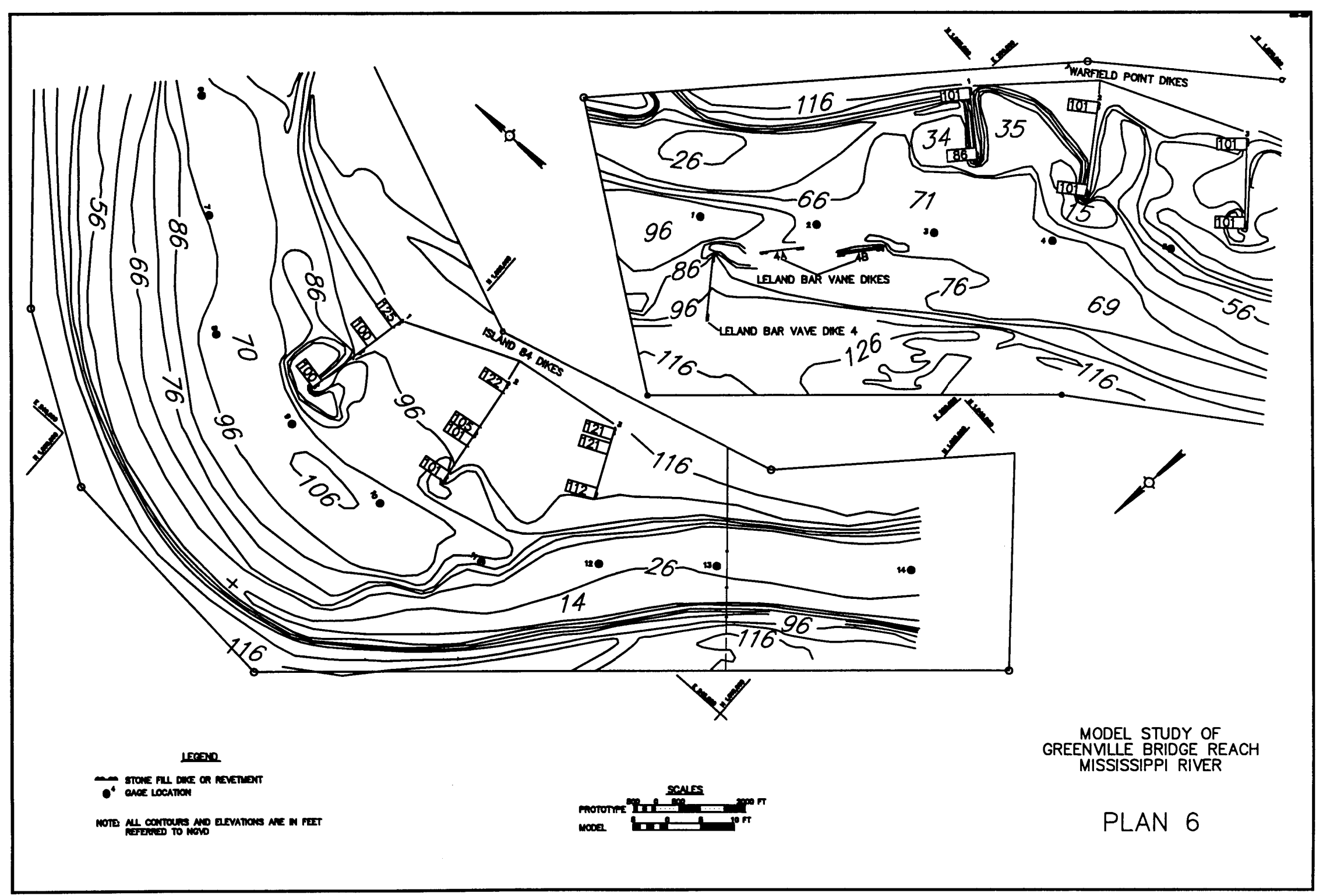

Figure 3. Plan 6 


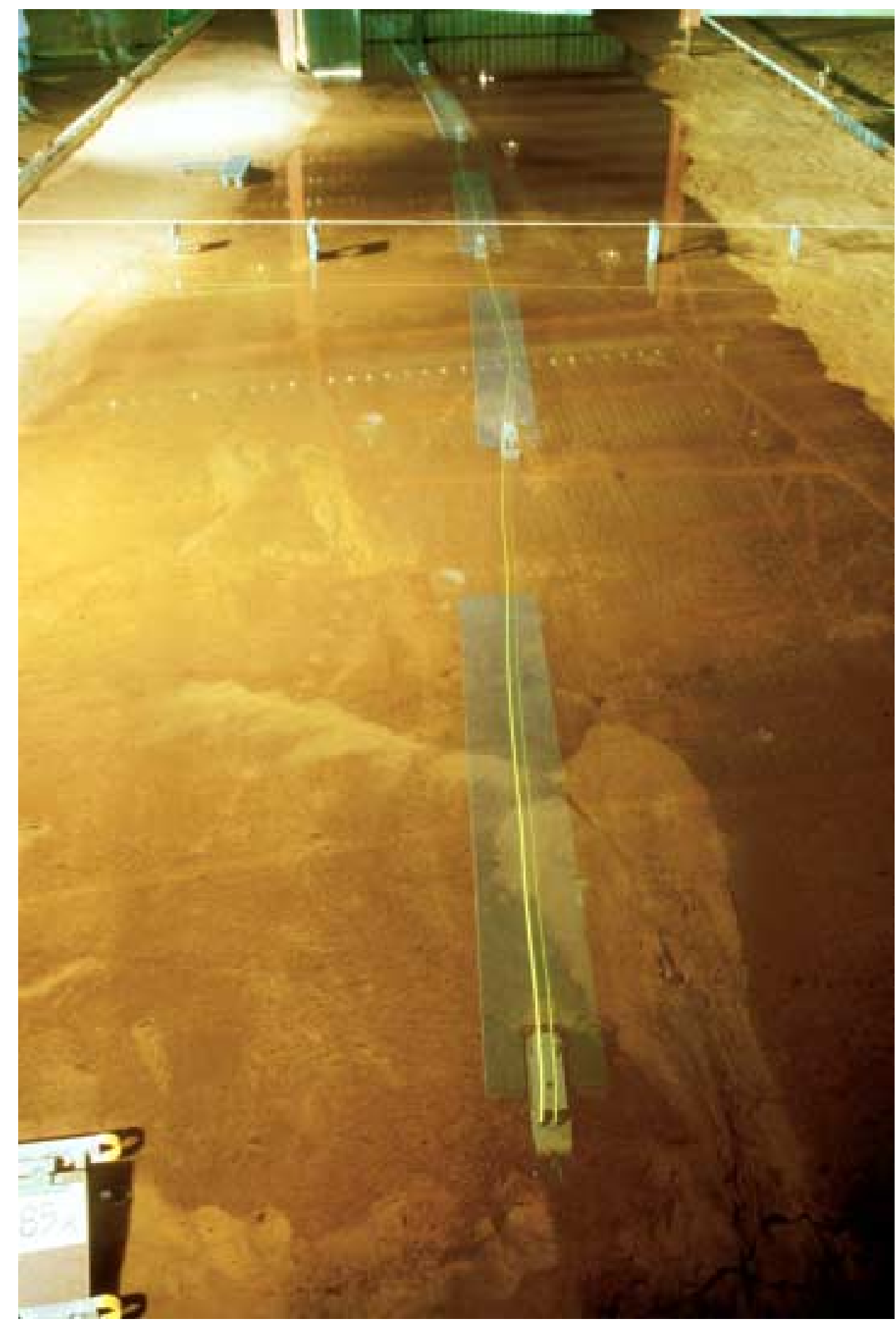

Photo 1. Option 5, discharge $185,000 \mathrm{cfs}$, looking upstream, showing path of upbound 35-barge tow navigating the reach 


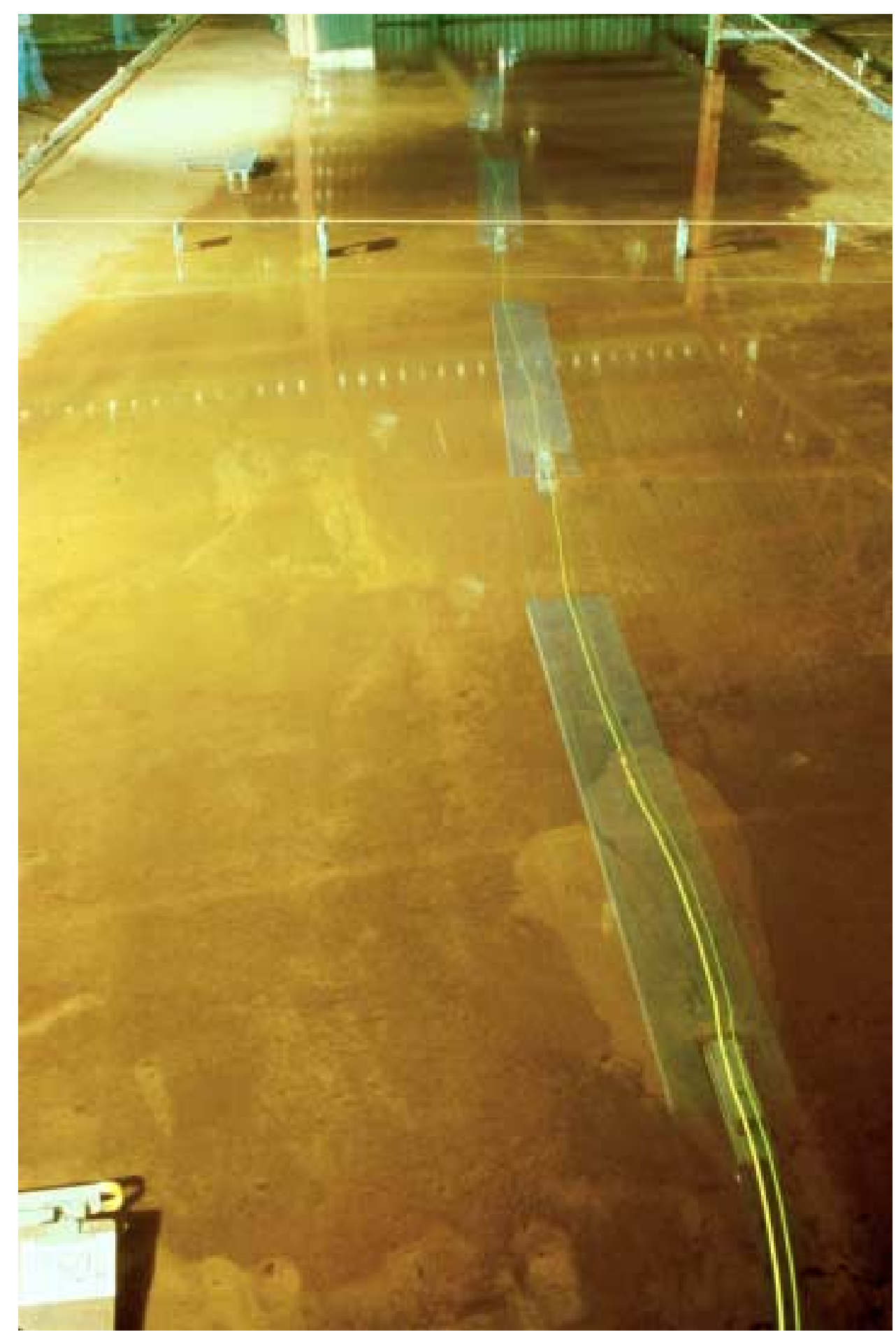

Photo 2. Option 5, discharge $750,000 \mathrm{cfs}$, looking upstream, showing path of upbound 35-barge tow navigating the reach 


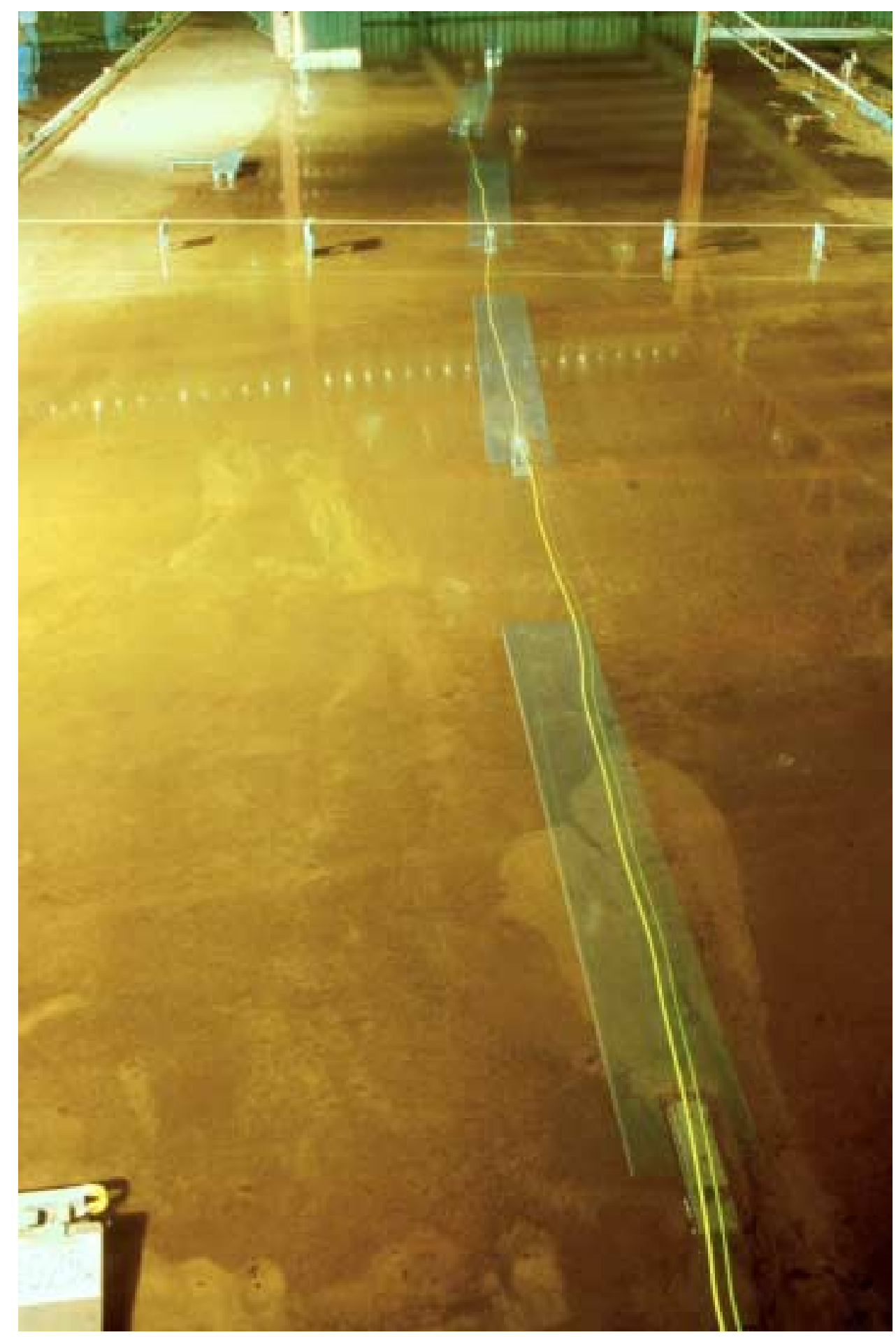

Photo 3. Option 5, discharge 1,025,000 cfs, looking upstream, showing path of upbound 35-barge tow navigating the reach 


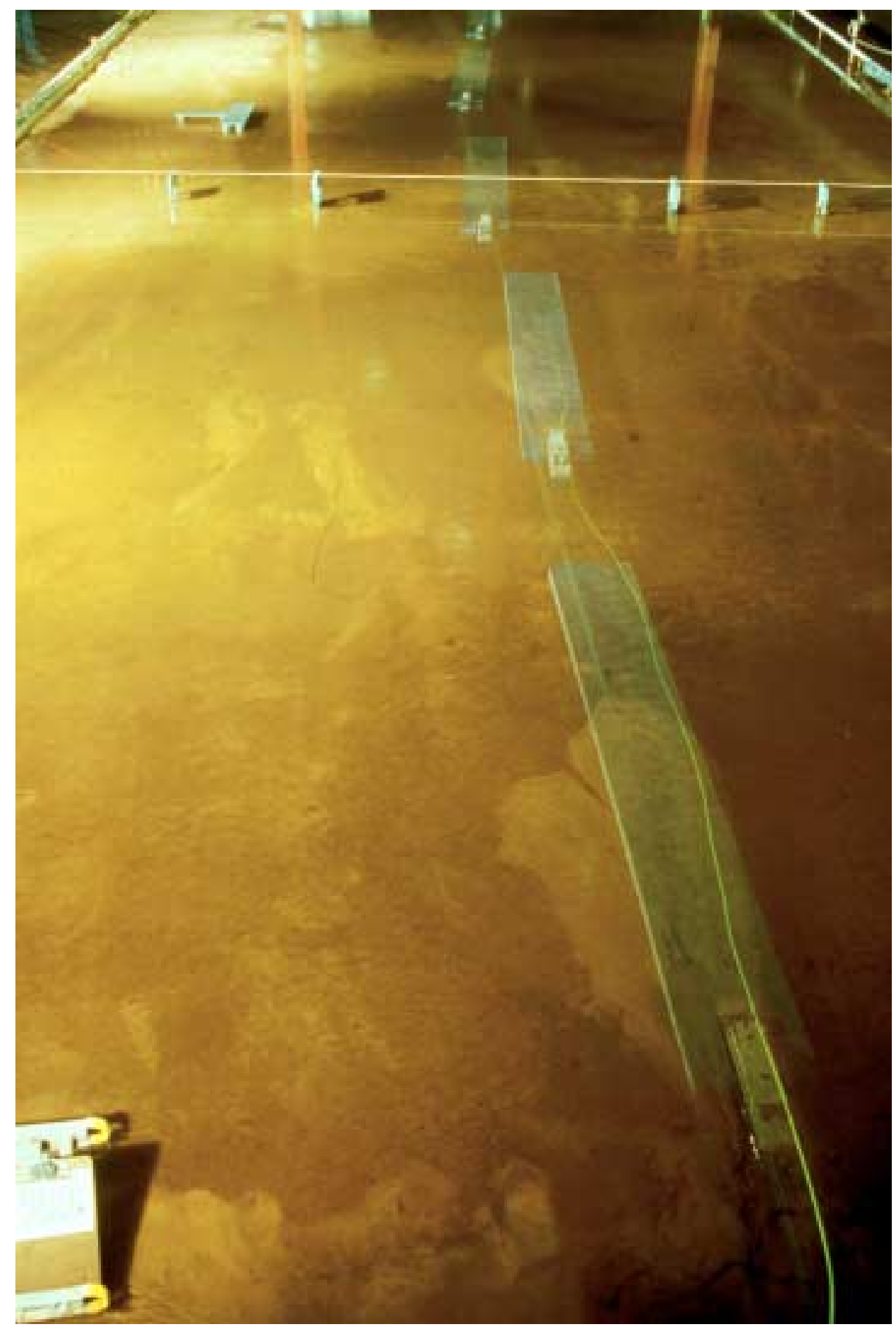

Photo 4. Option 5, discharge 1,500,000 cfs, looking upstream, showing path of upbound 35-barge tow navigating the reach 


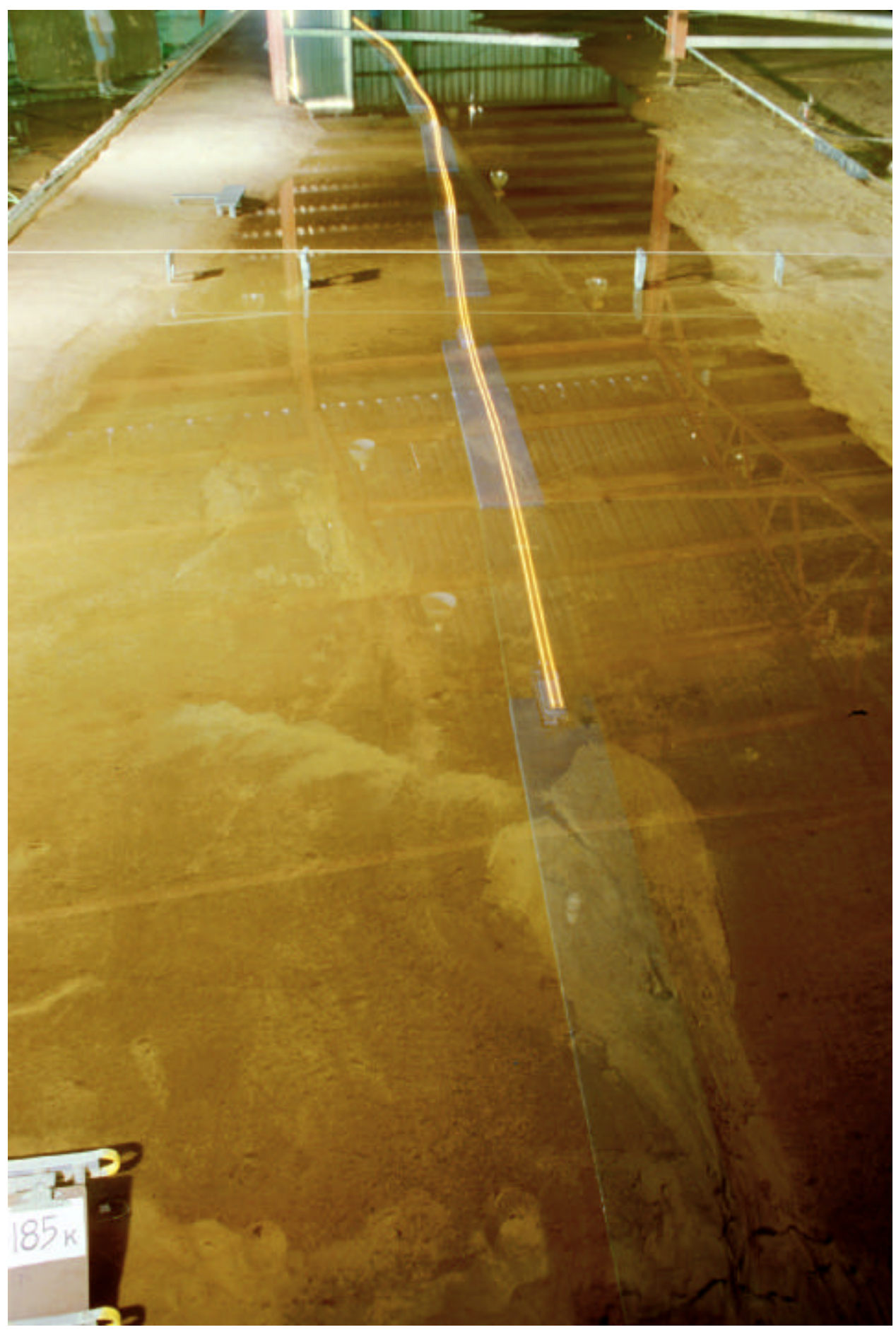

Photo 5. Option 5, discharge $185,000 \mathrm{cfs}$, looking upstream, showing path of downbound 35-barge tow driving the bend upstream of the bridge 


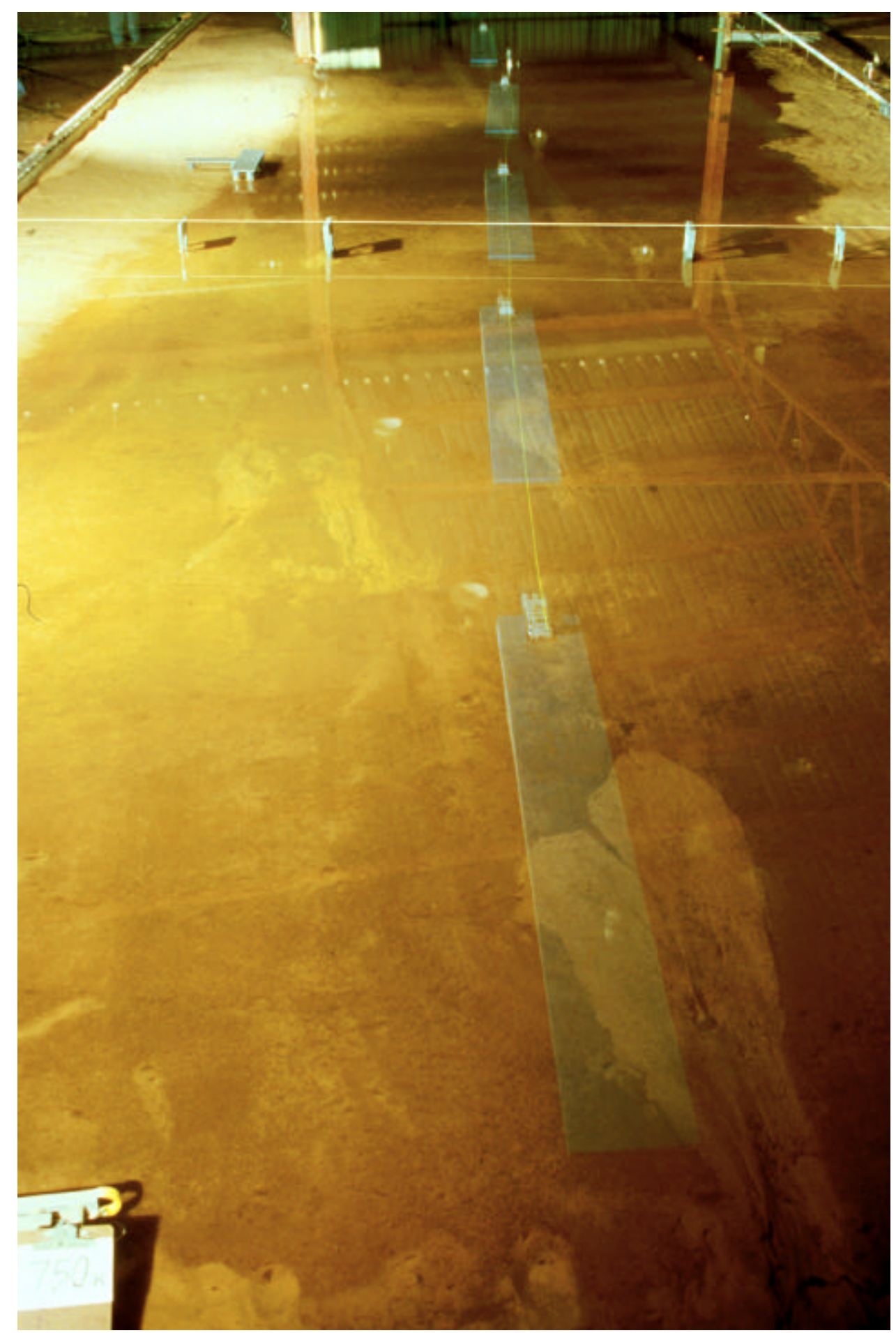

Photo 6. Option 5, discharge $750,000 \mathrm{cfs}$, looking upstream, showing path of downbound 35-barge tow driving the bend upstream of the bridge 


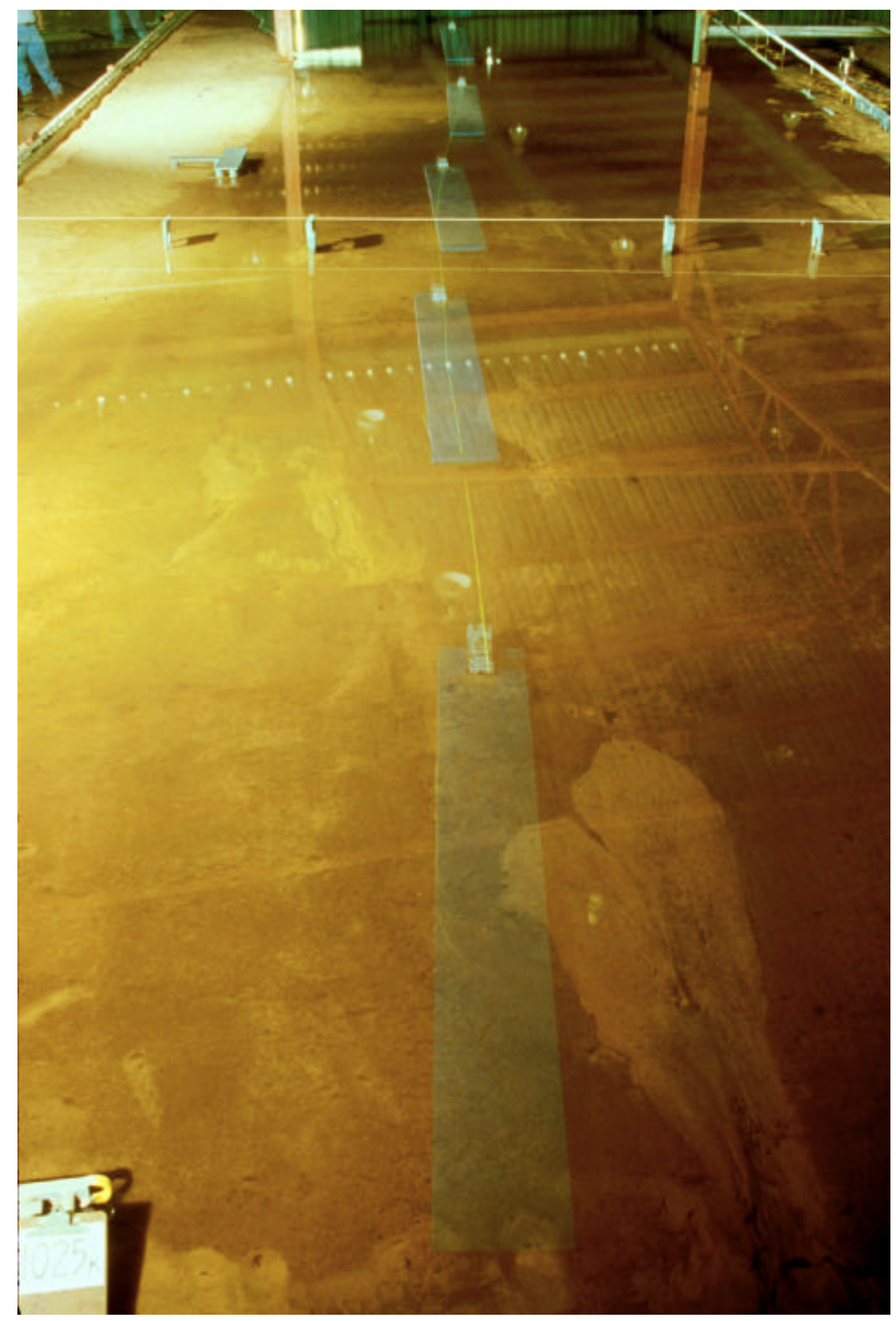

Photo 7. Option 5, discharge $1,025,000 \mathrm{cfs}$, looking upstream, showing path of downbound 35-barge tow driving the bend upstream of the bridge 


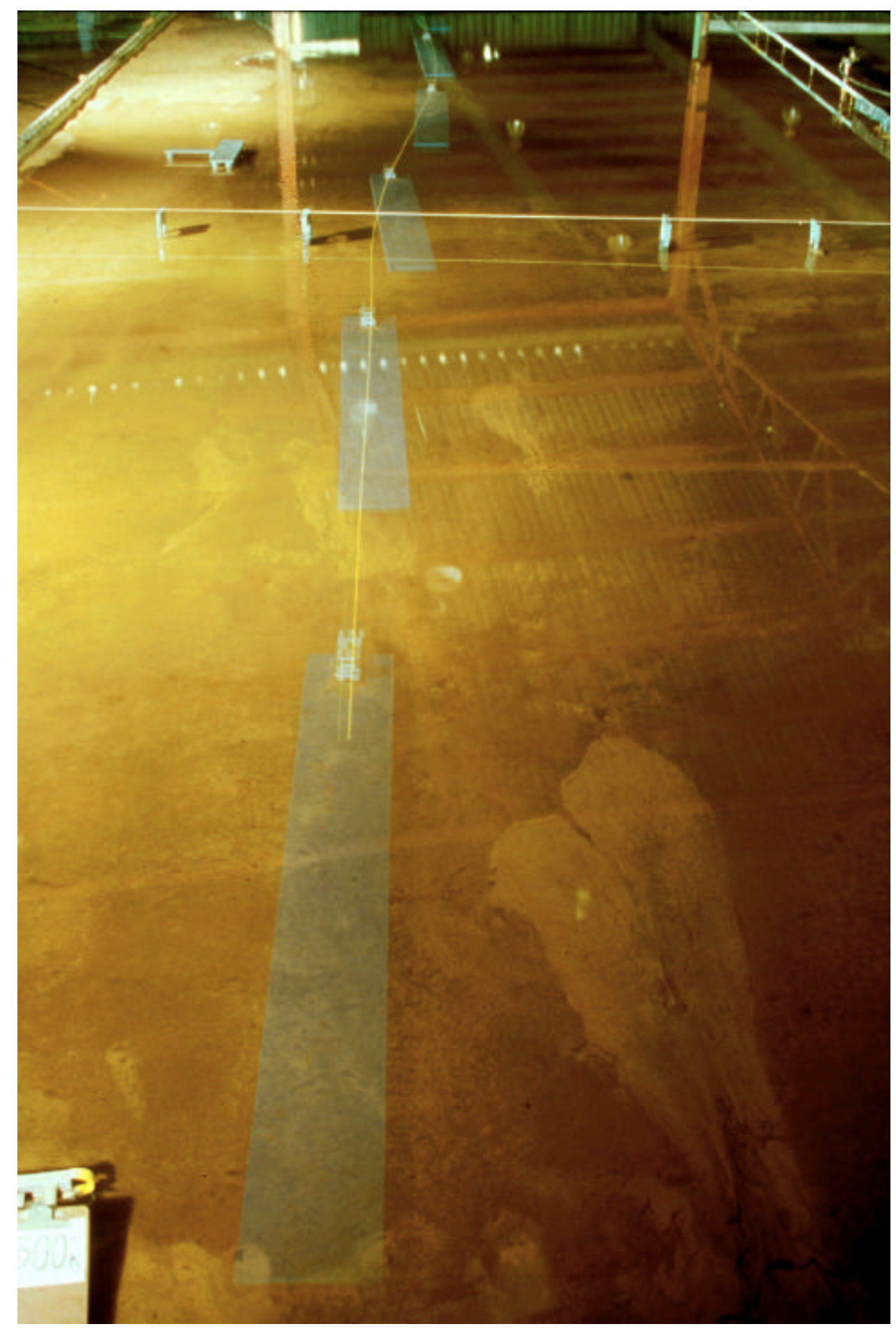

Photo 8. Option 5, discharge 1,500,000 cfs, looking upstream, showing path of downbound 35-barge tow driving the bend upstream of the bridge 


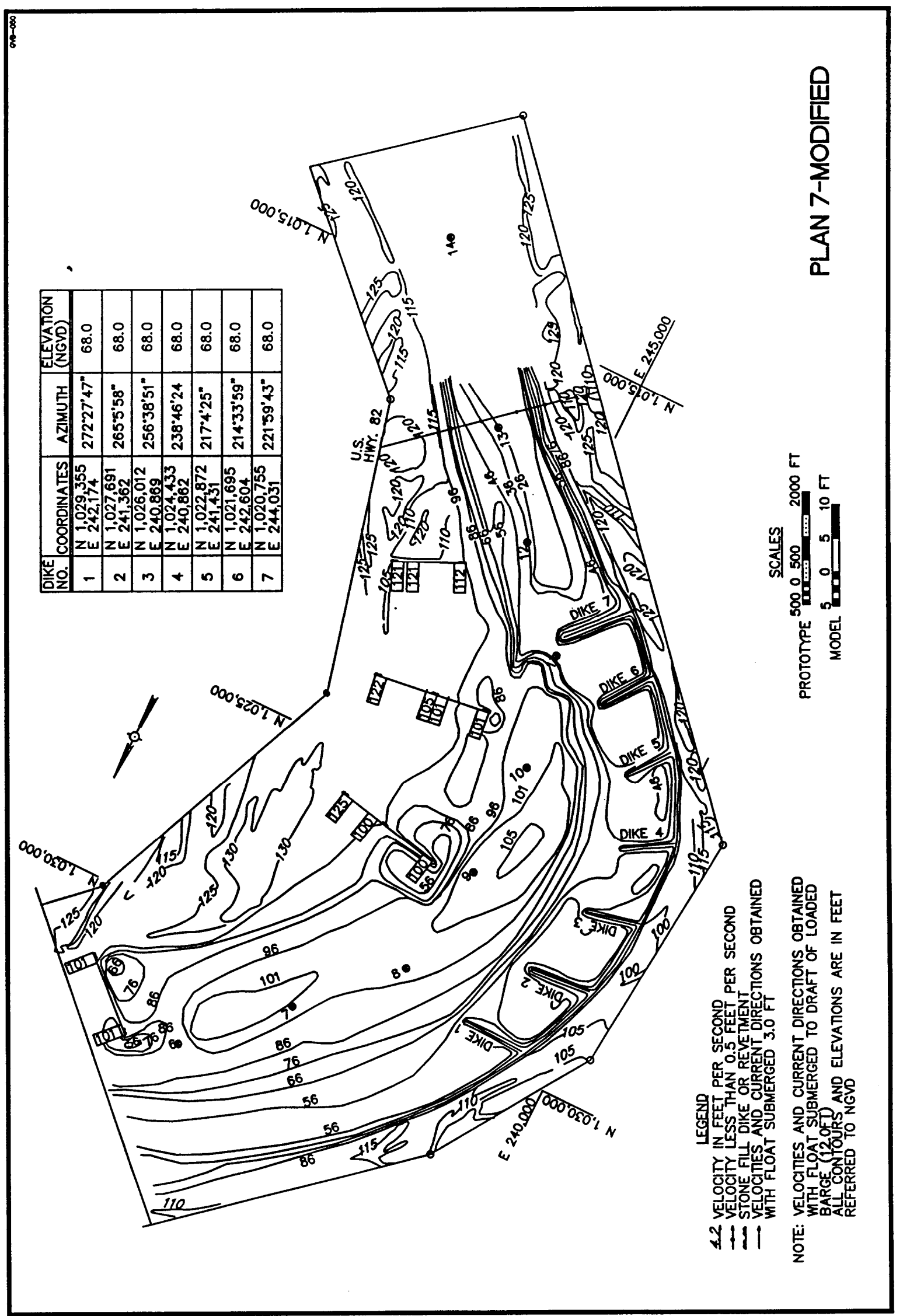




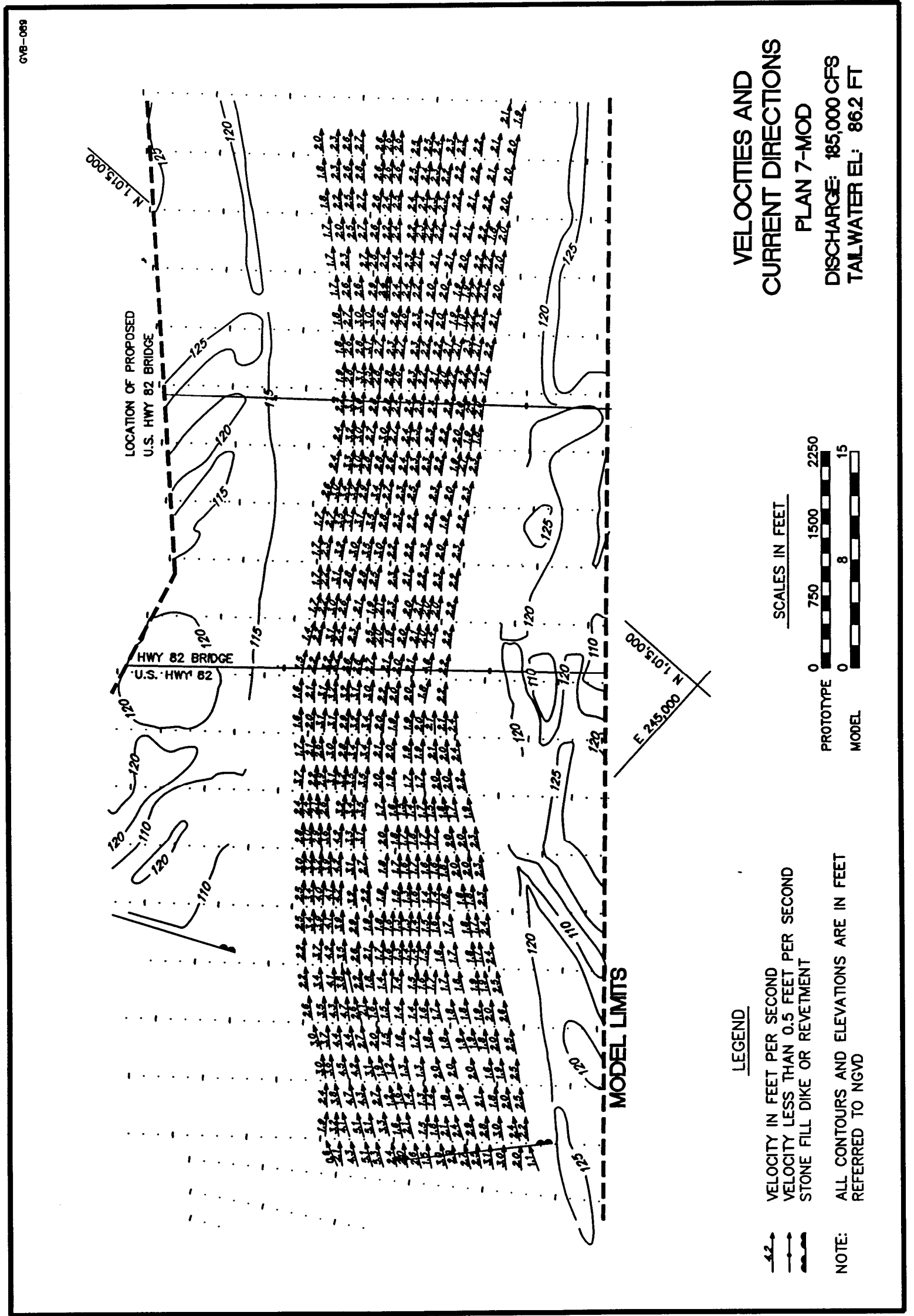

Plate 2 


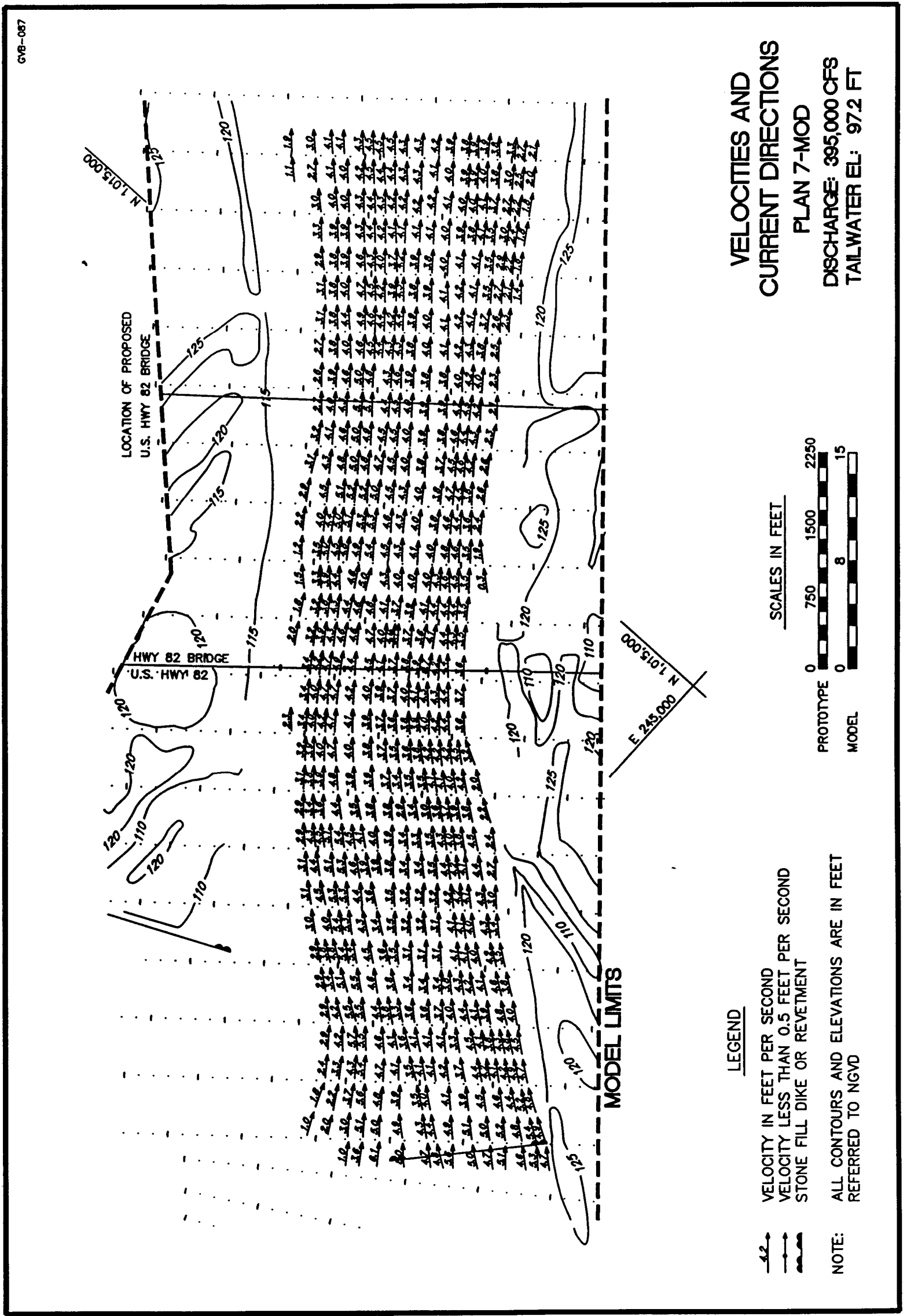

Plate 3 


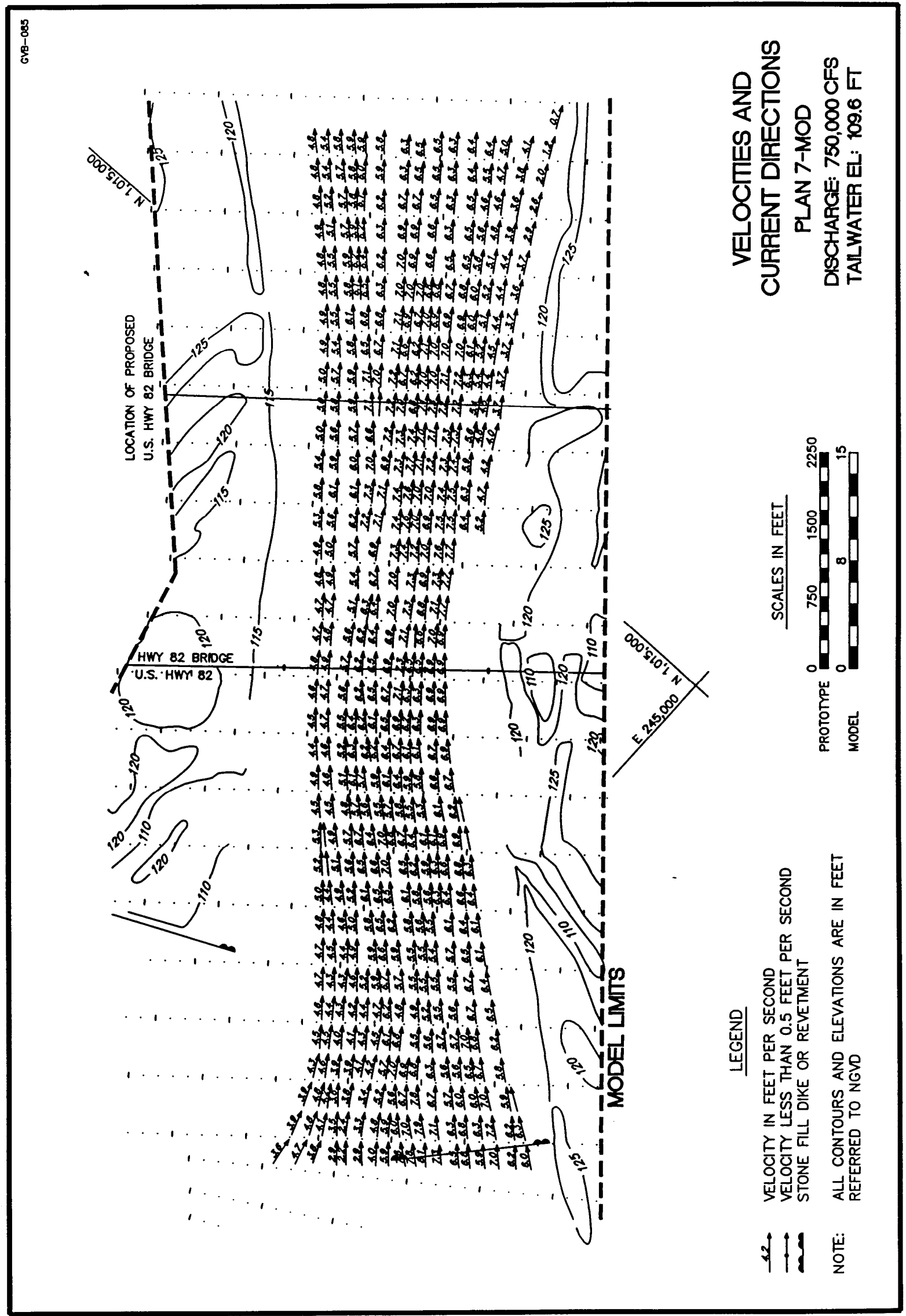

Plate 4 


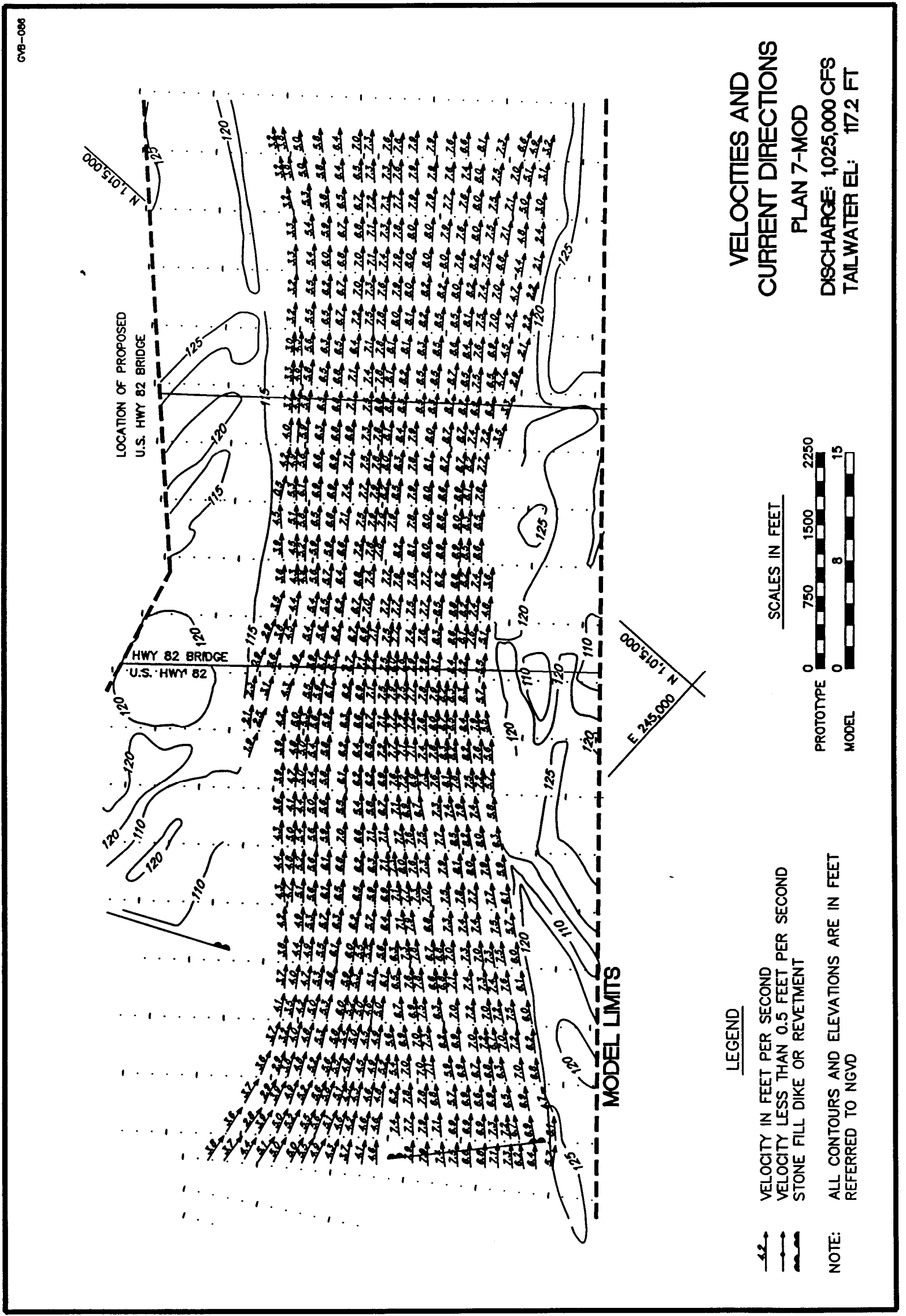




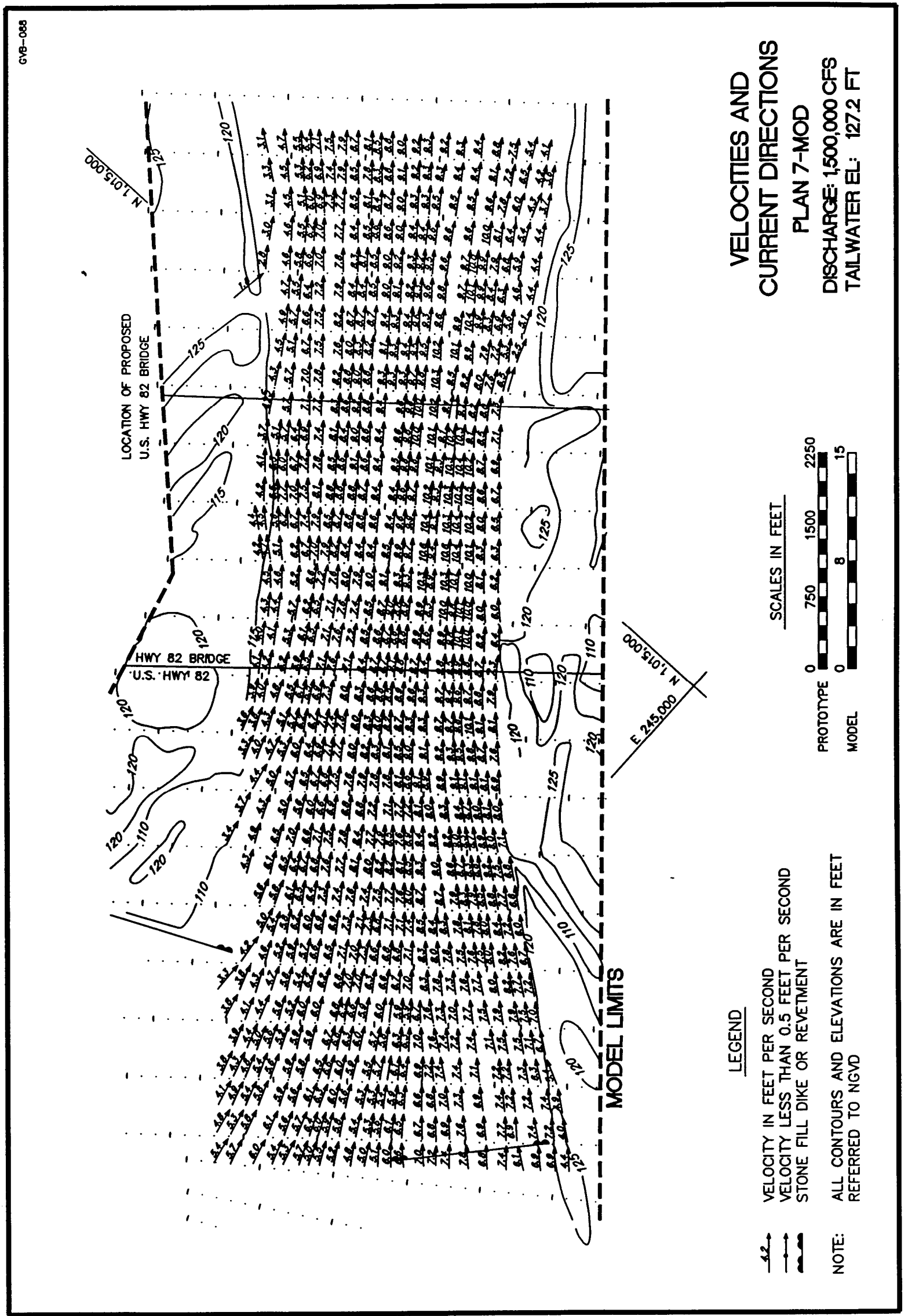

Plate 6 


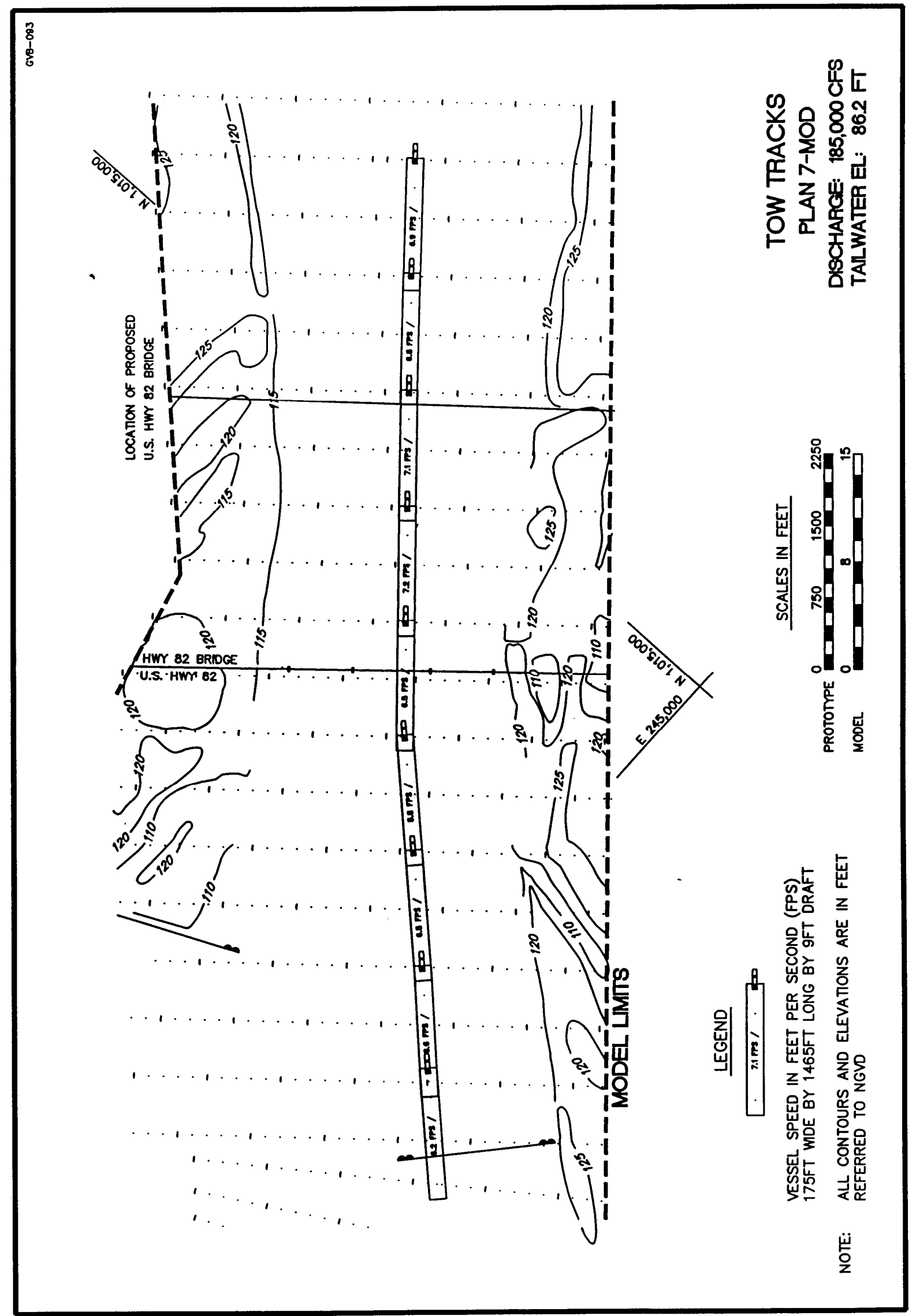

Plate 7 


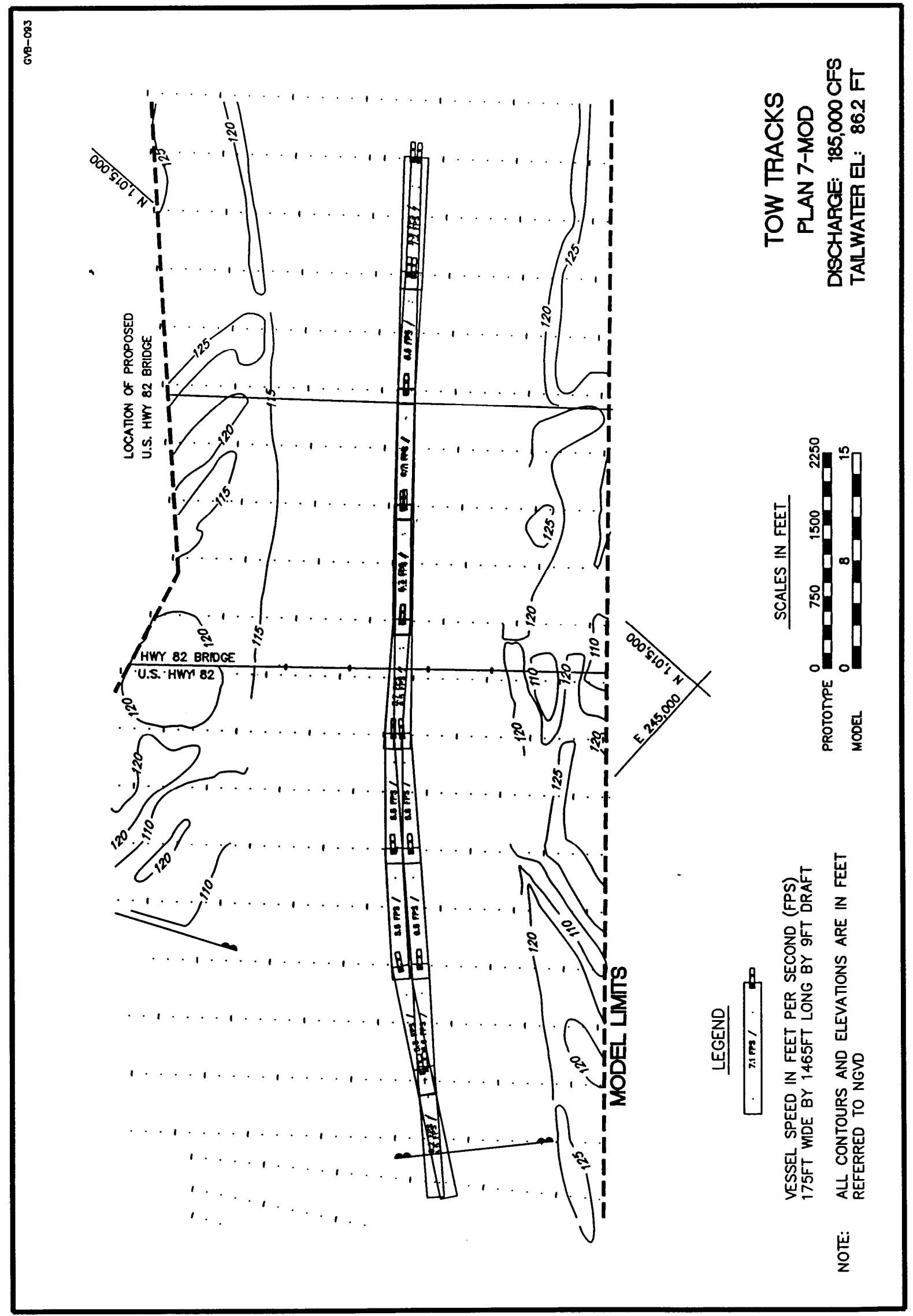

Plate 8 

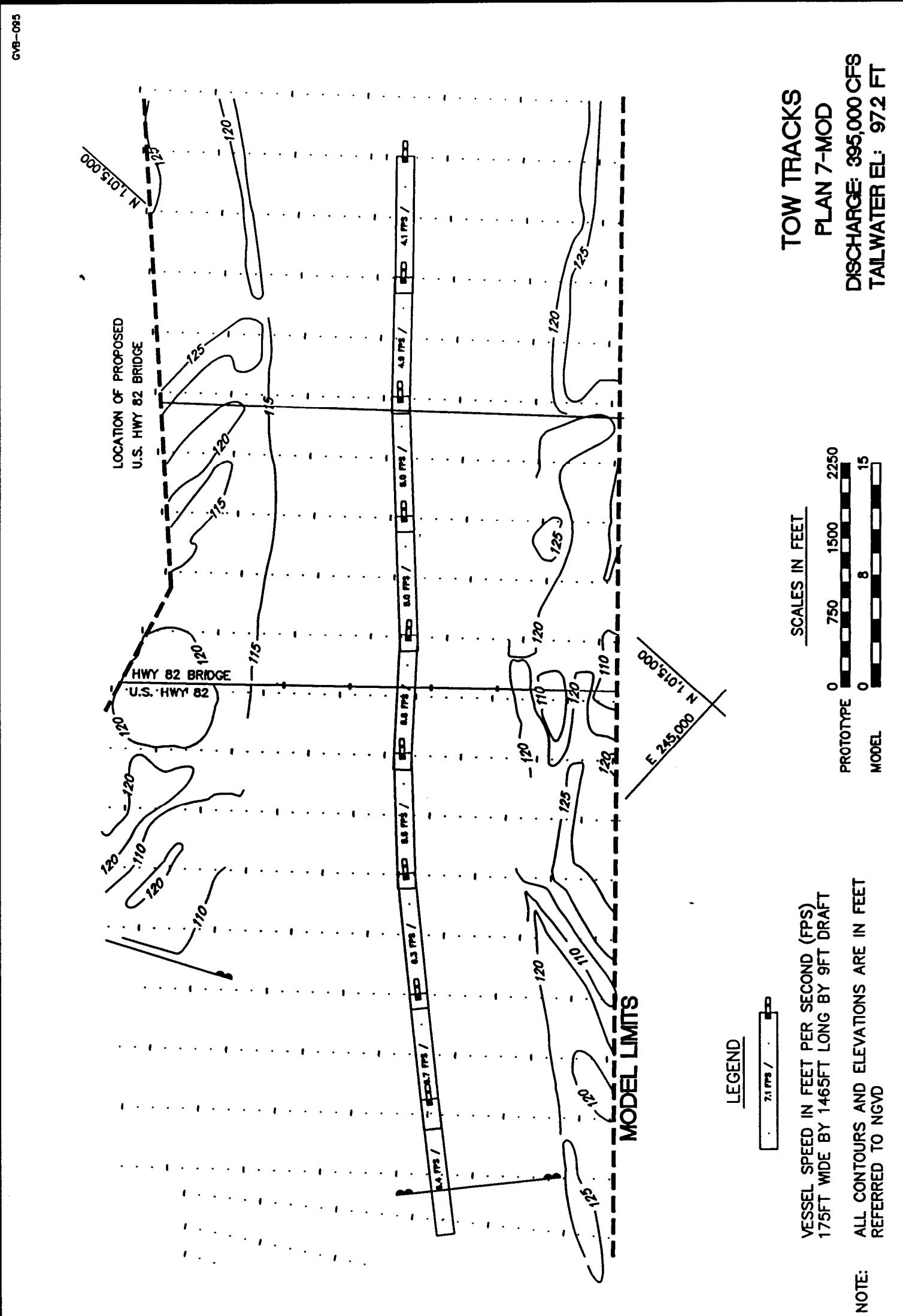


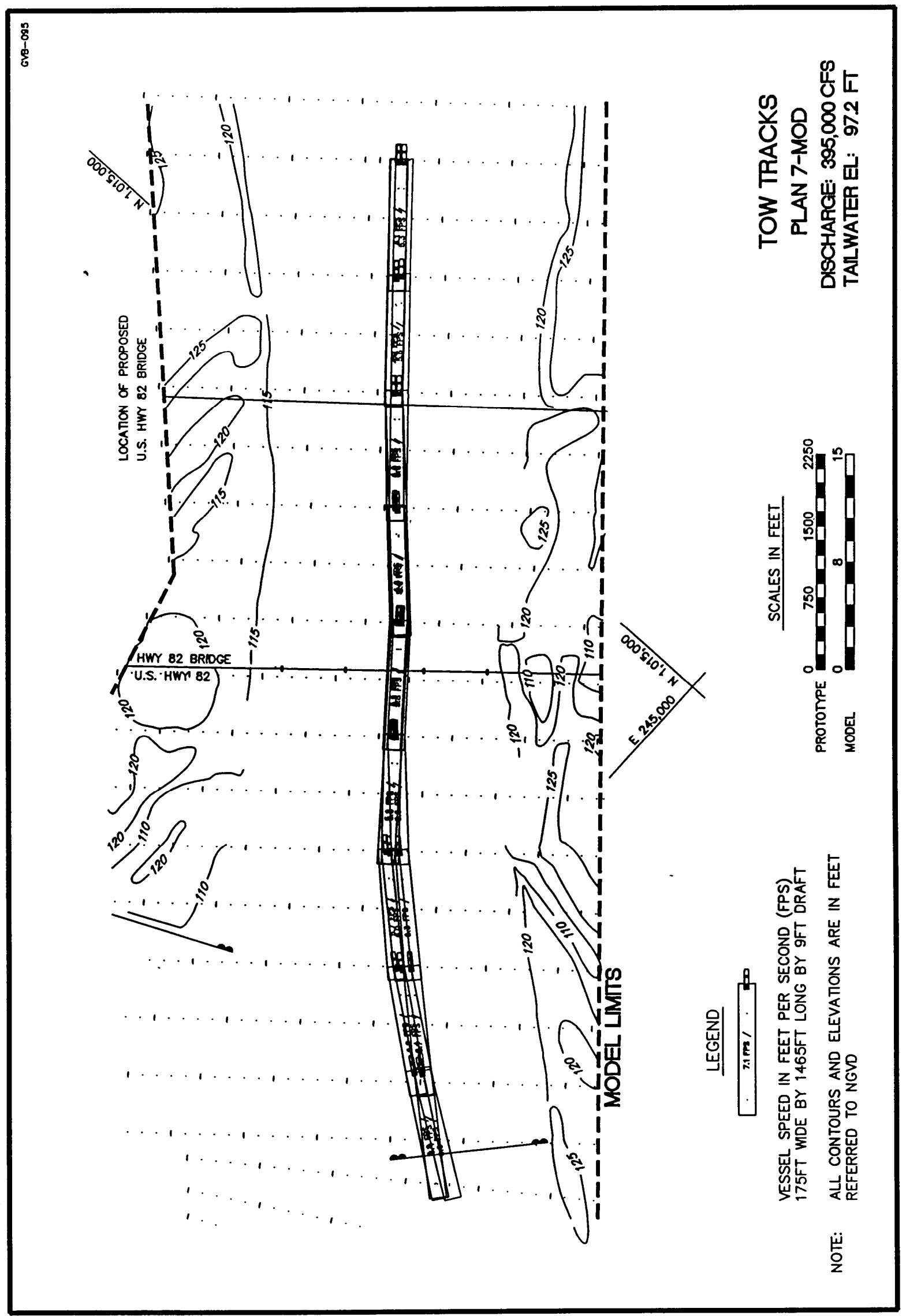

Plate 10 


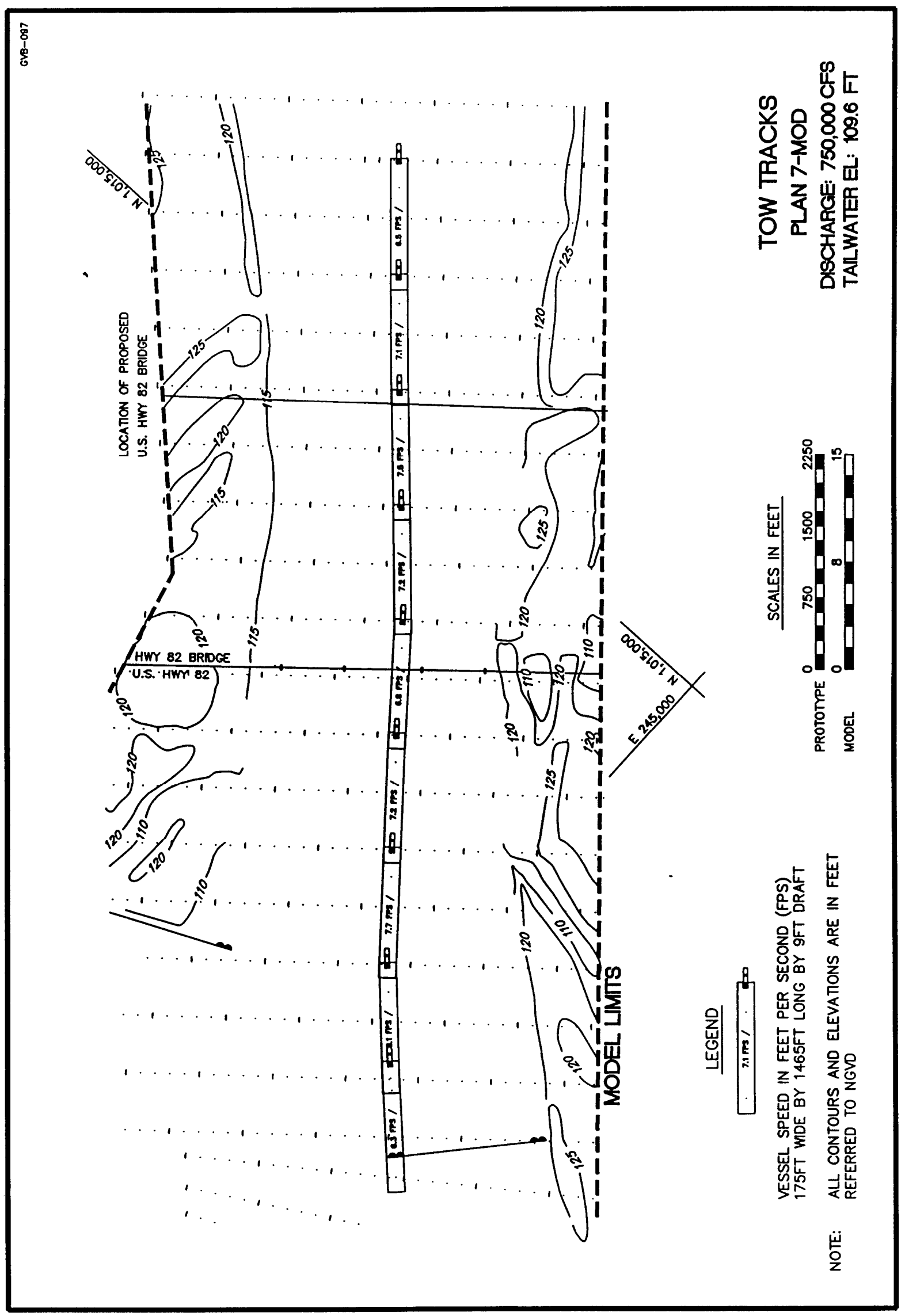

Plate 11 


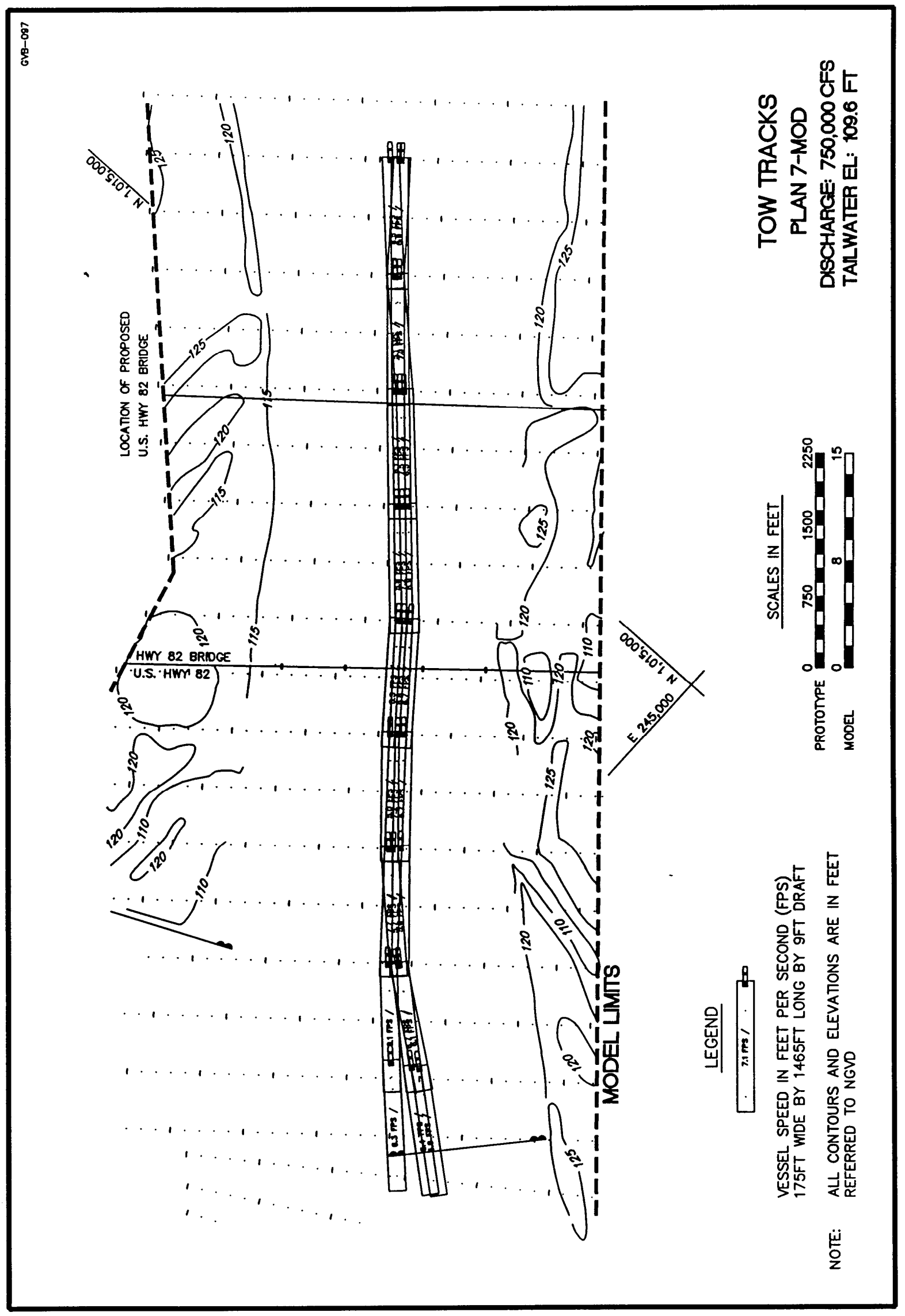

Plate 12 


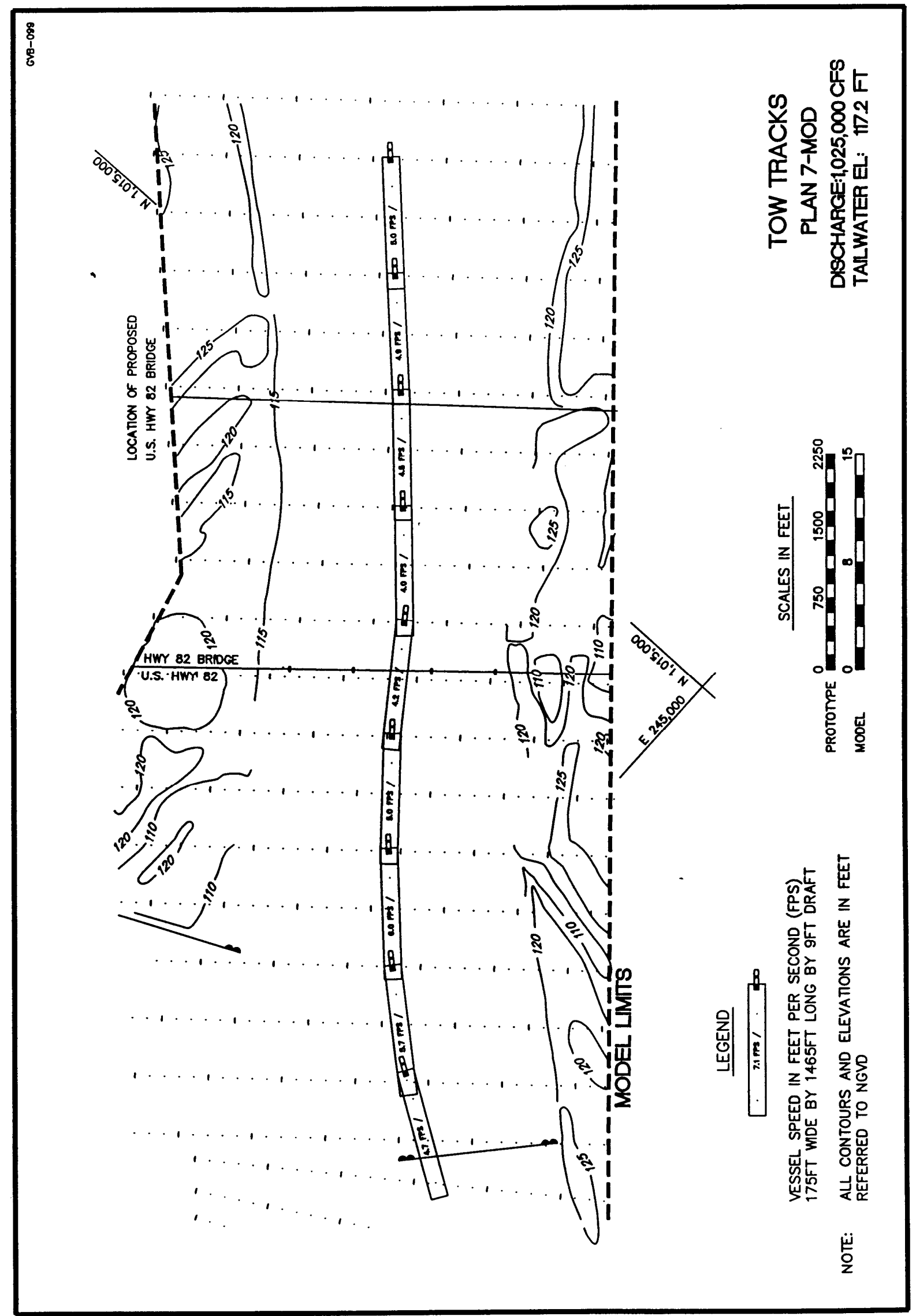

Plate 13 


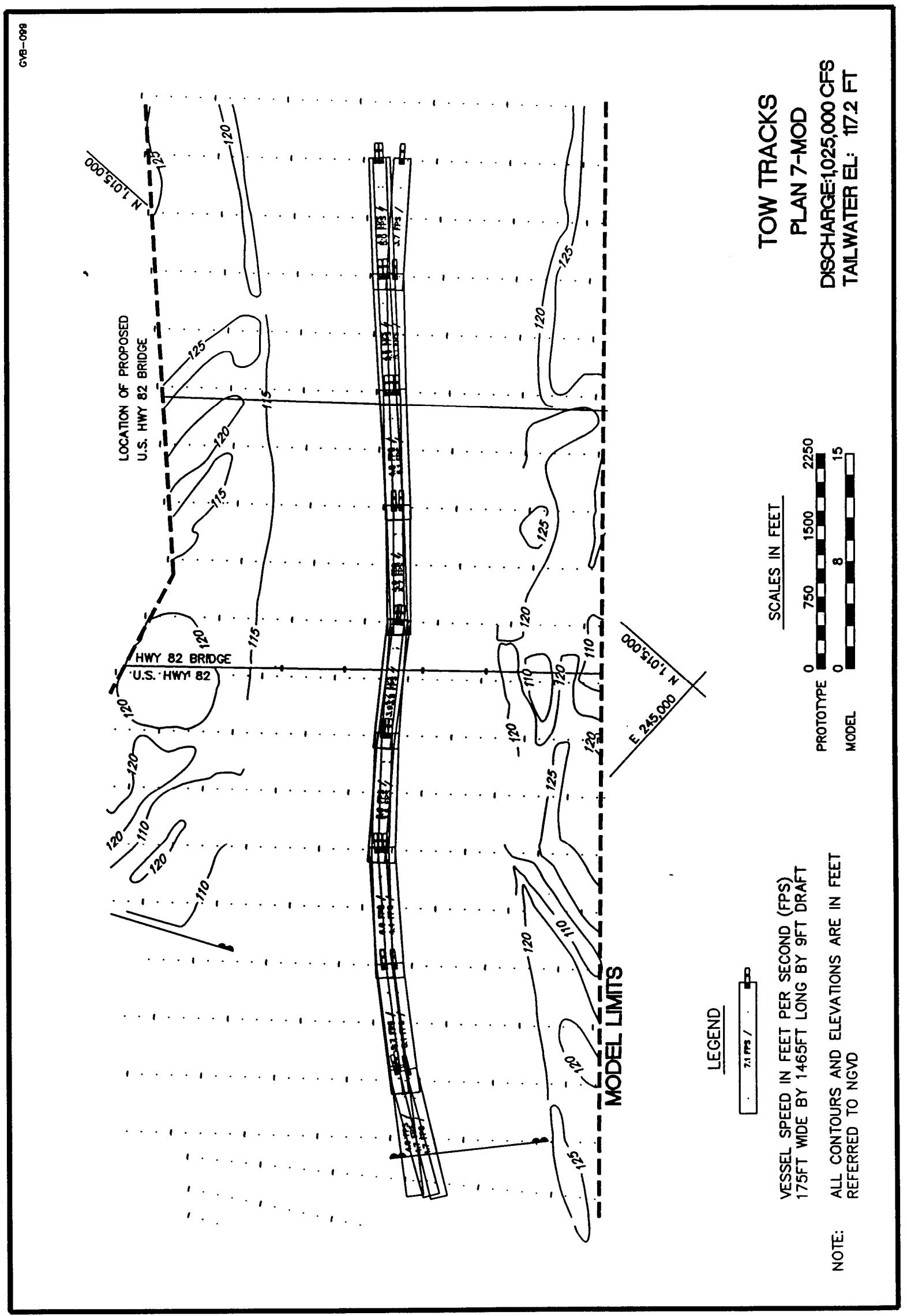

Plate 14 


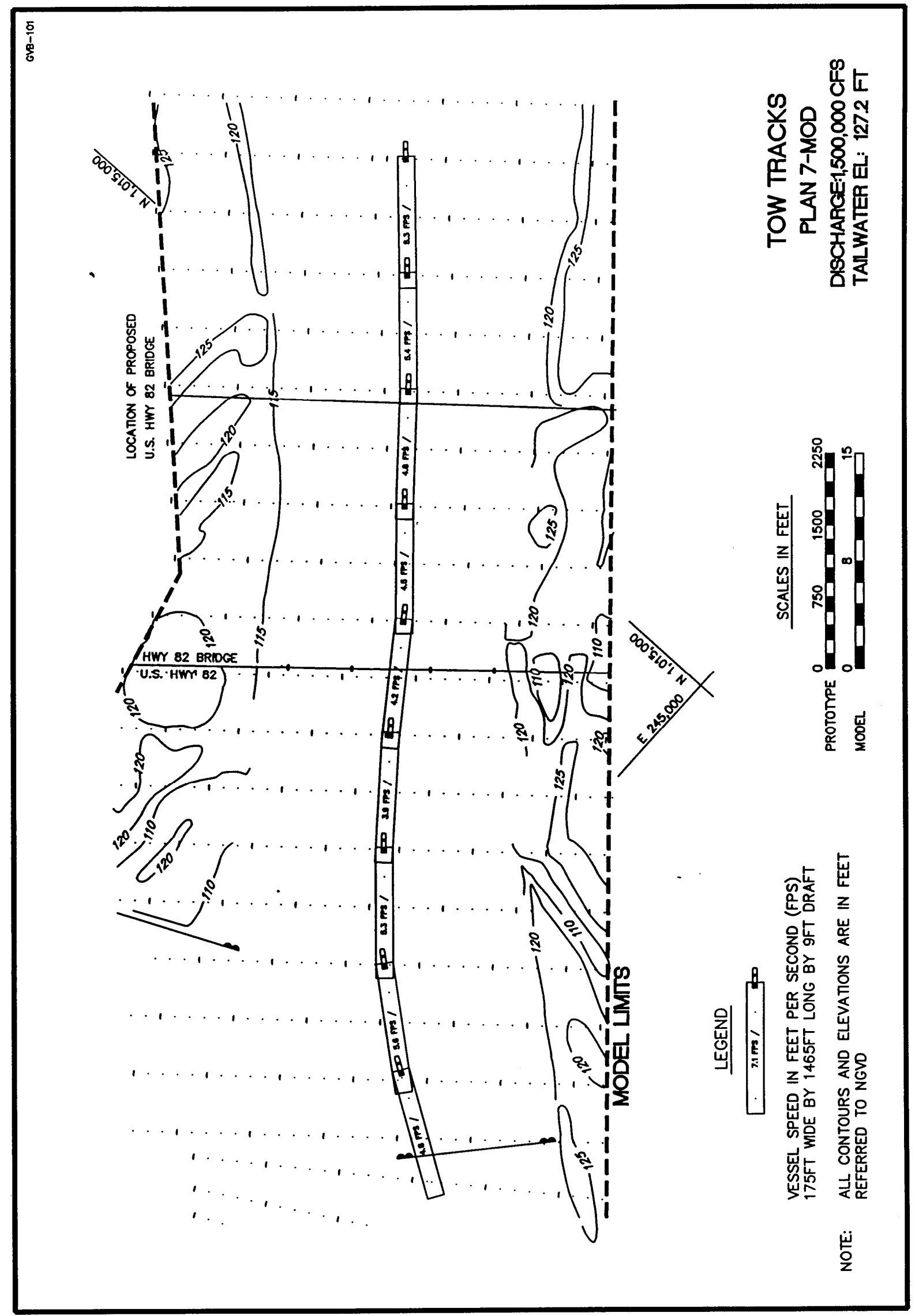

Plate 15 


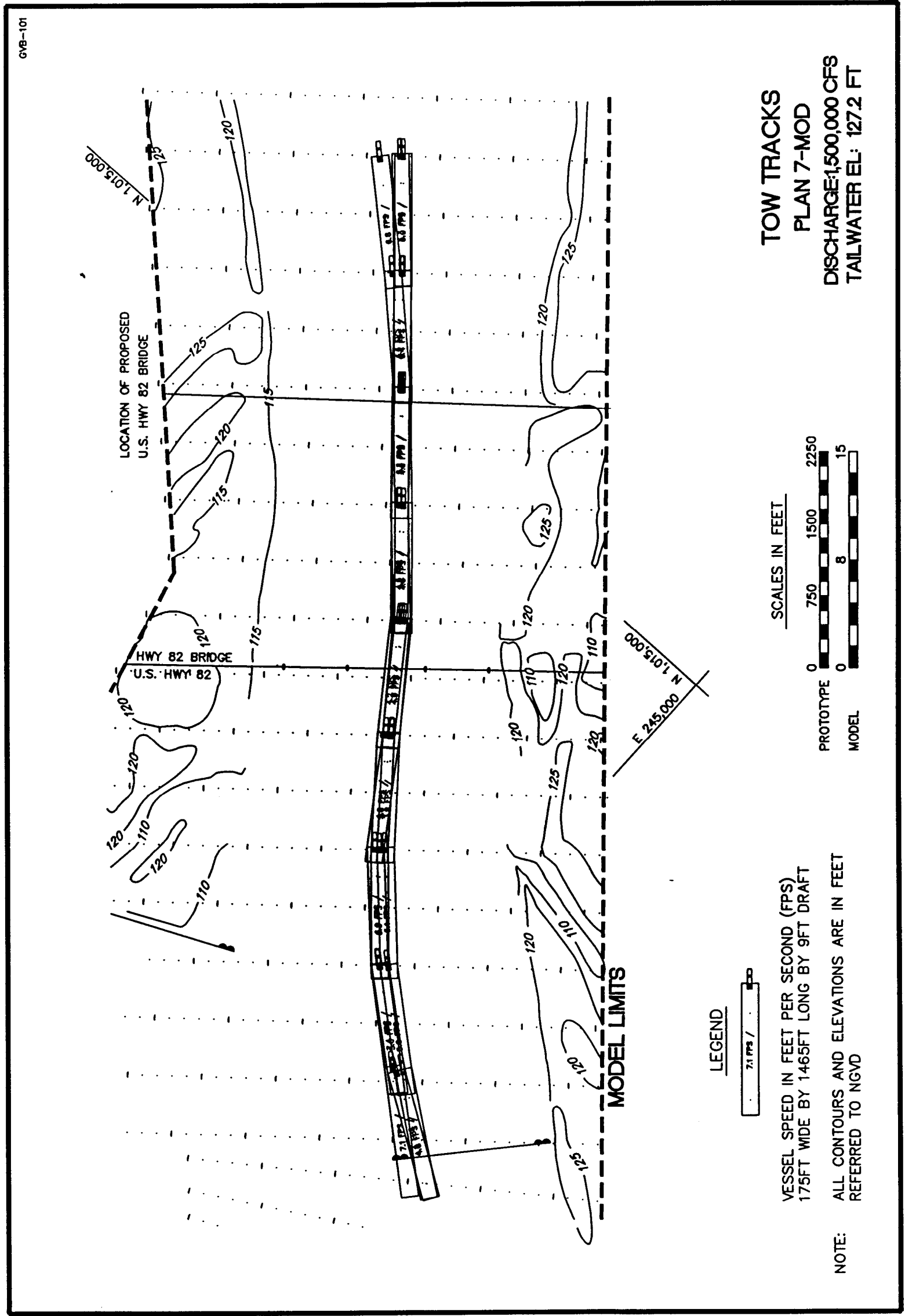

Plate 16 


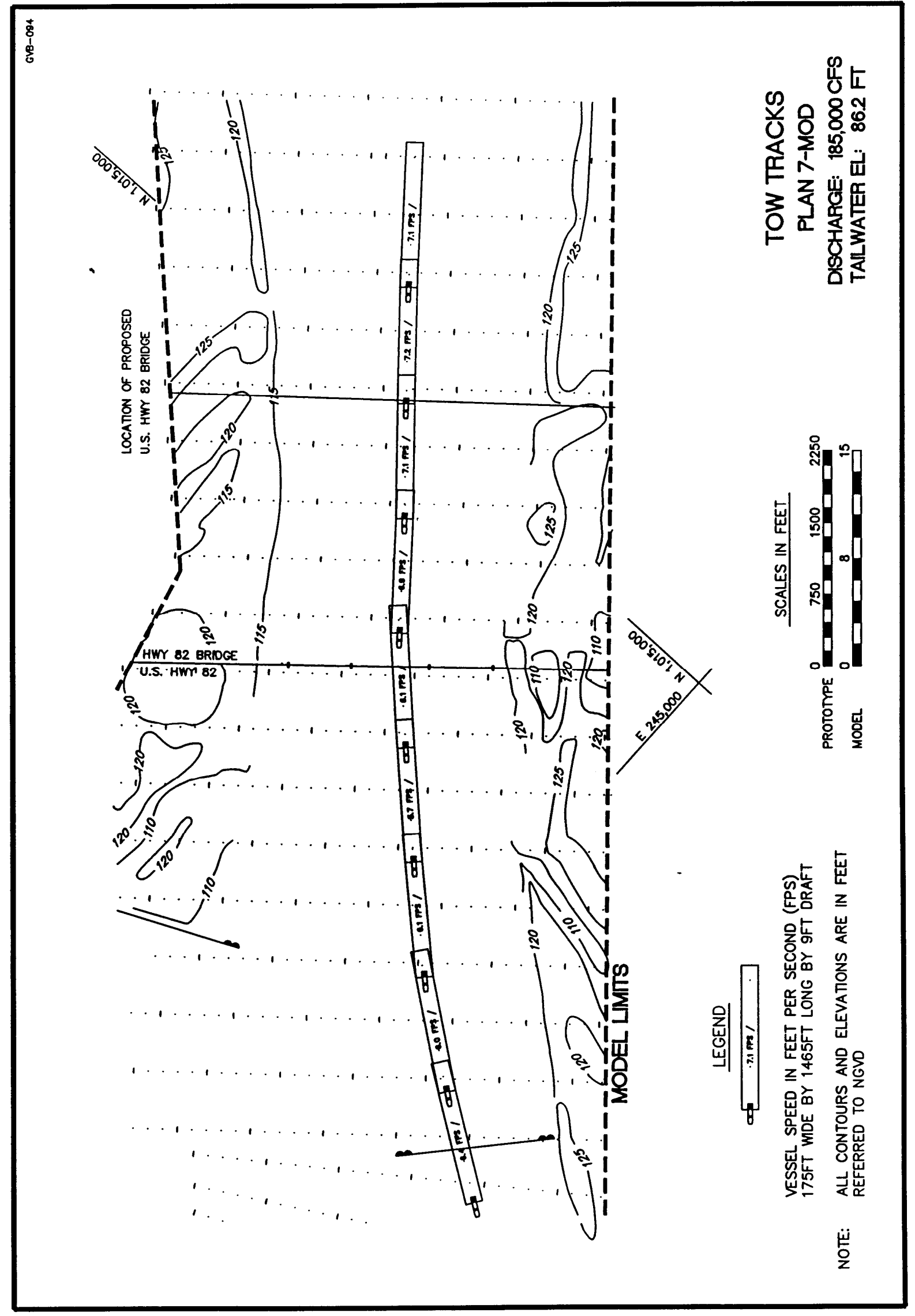

Plate 17 


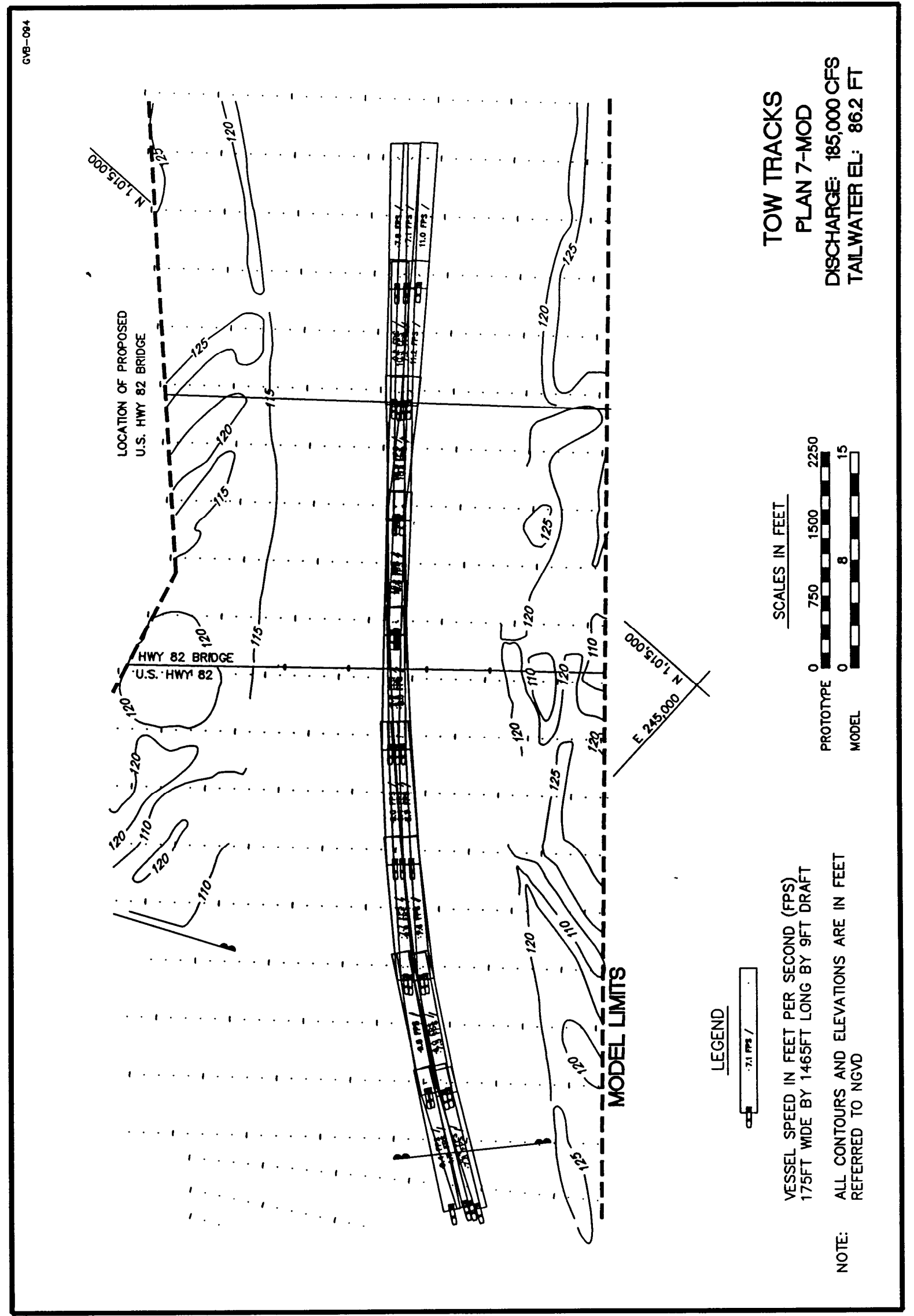

Plate 18 


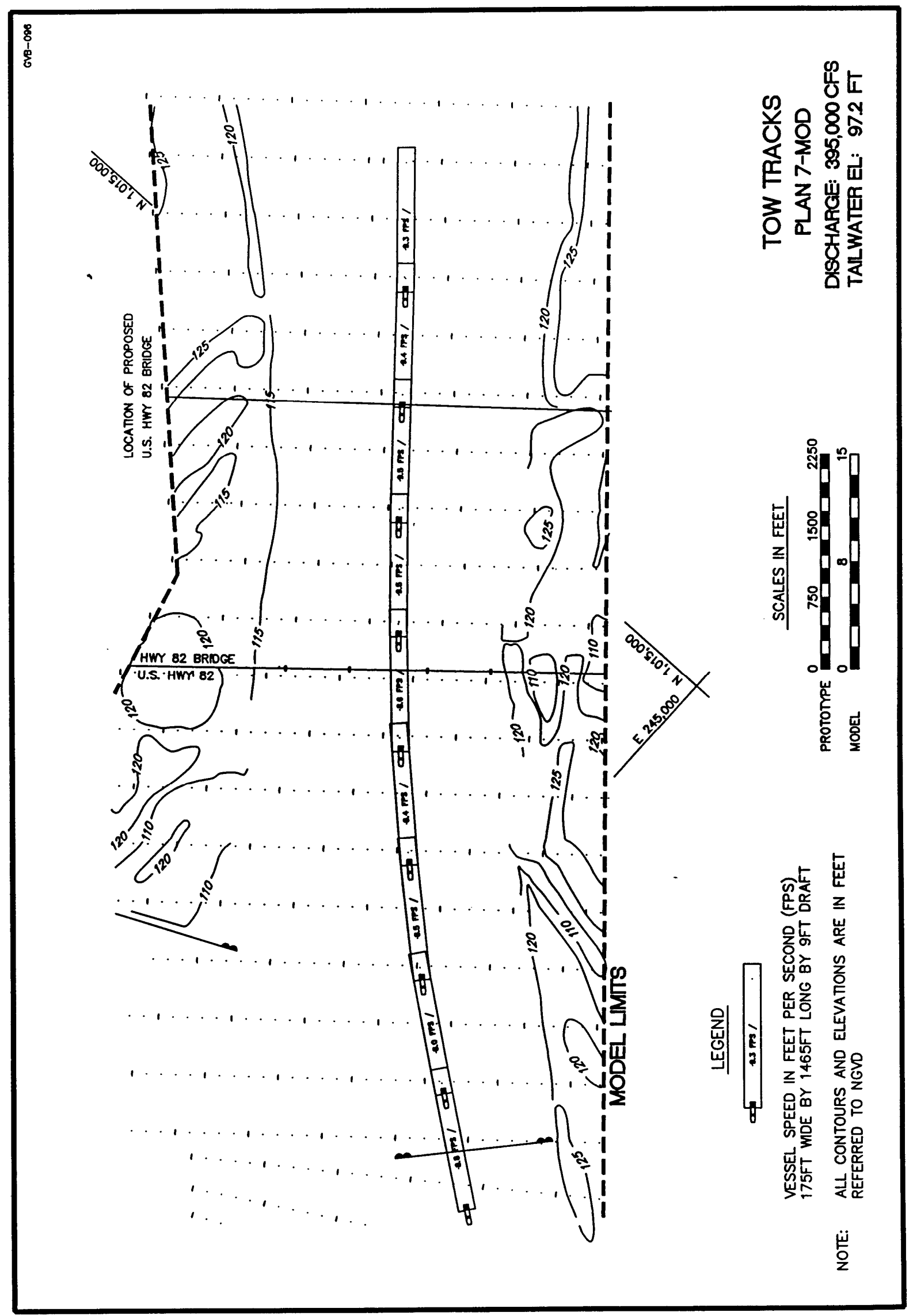

Plate 19 


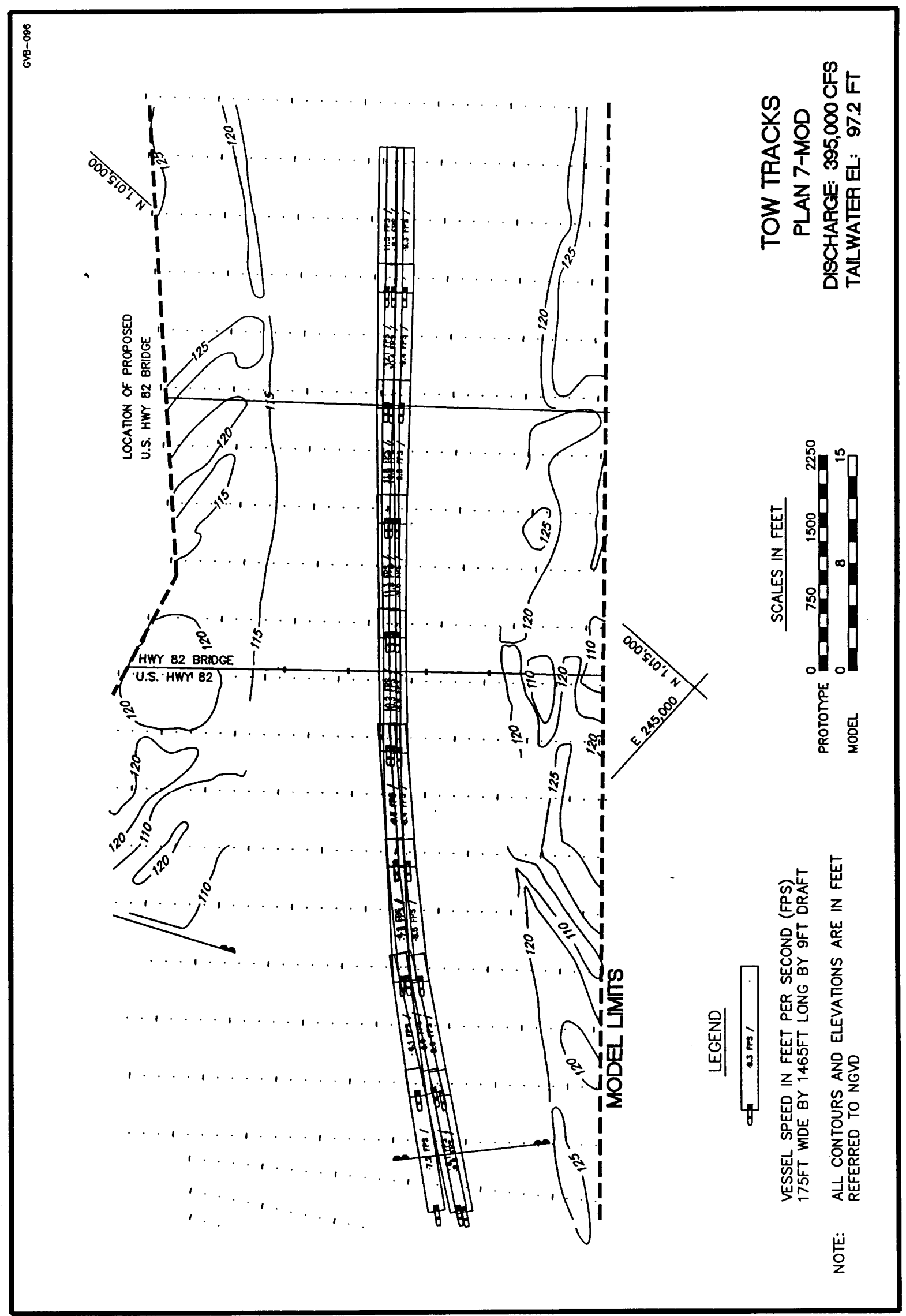

Plate 20 


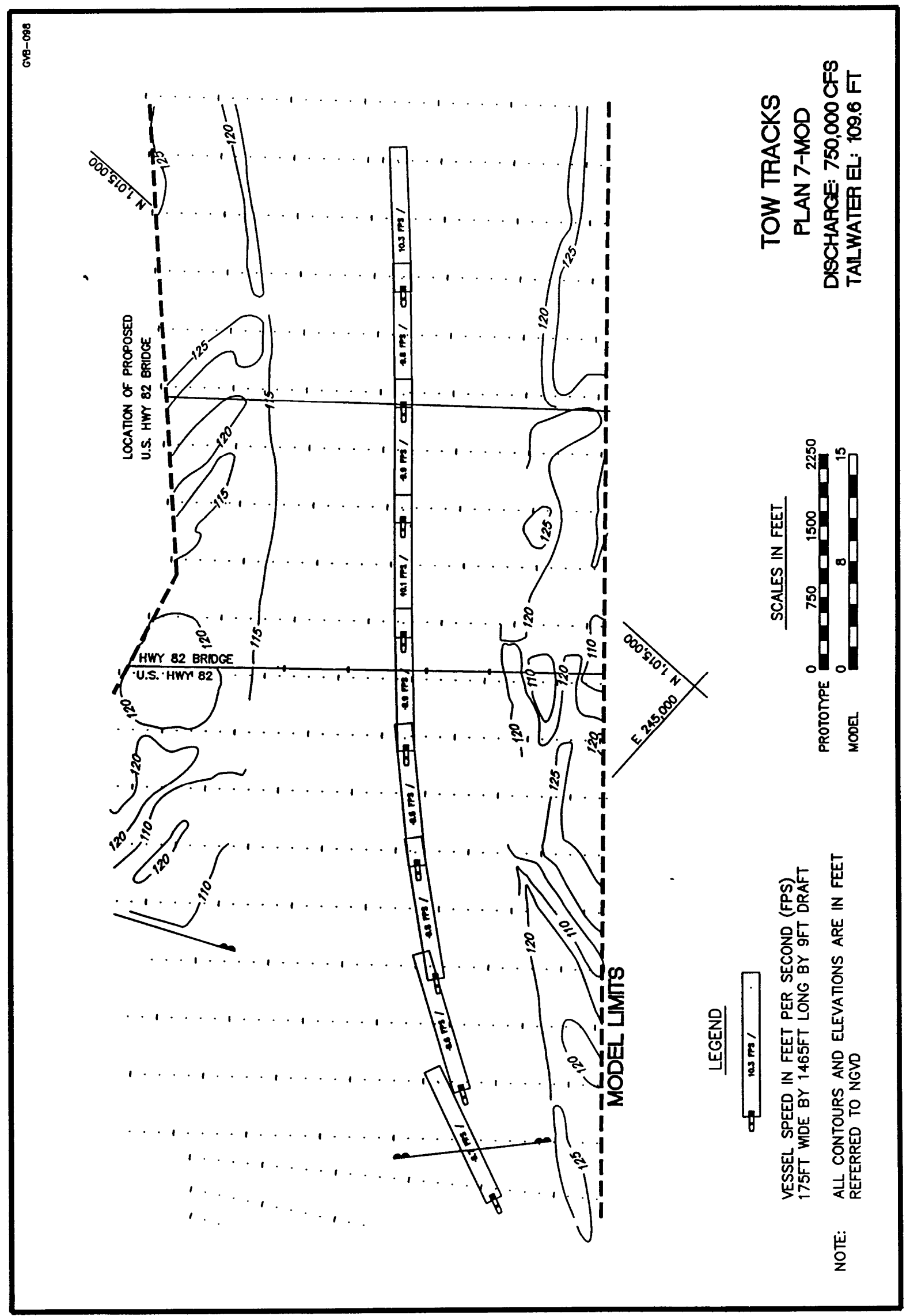

Plate 21 


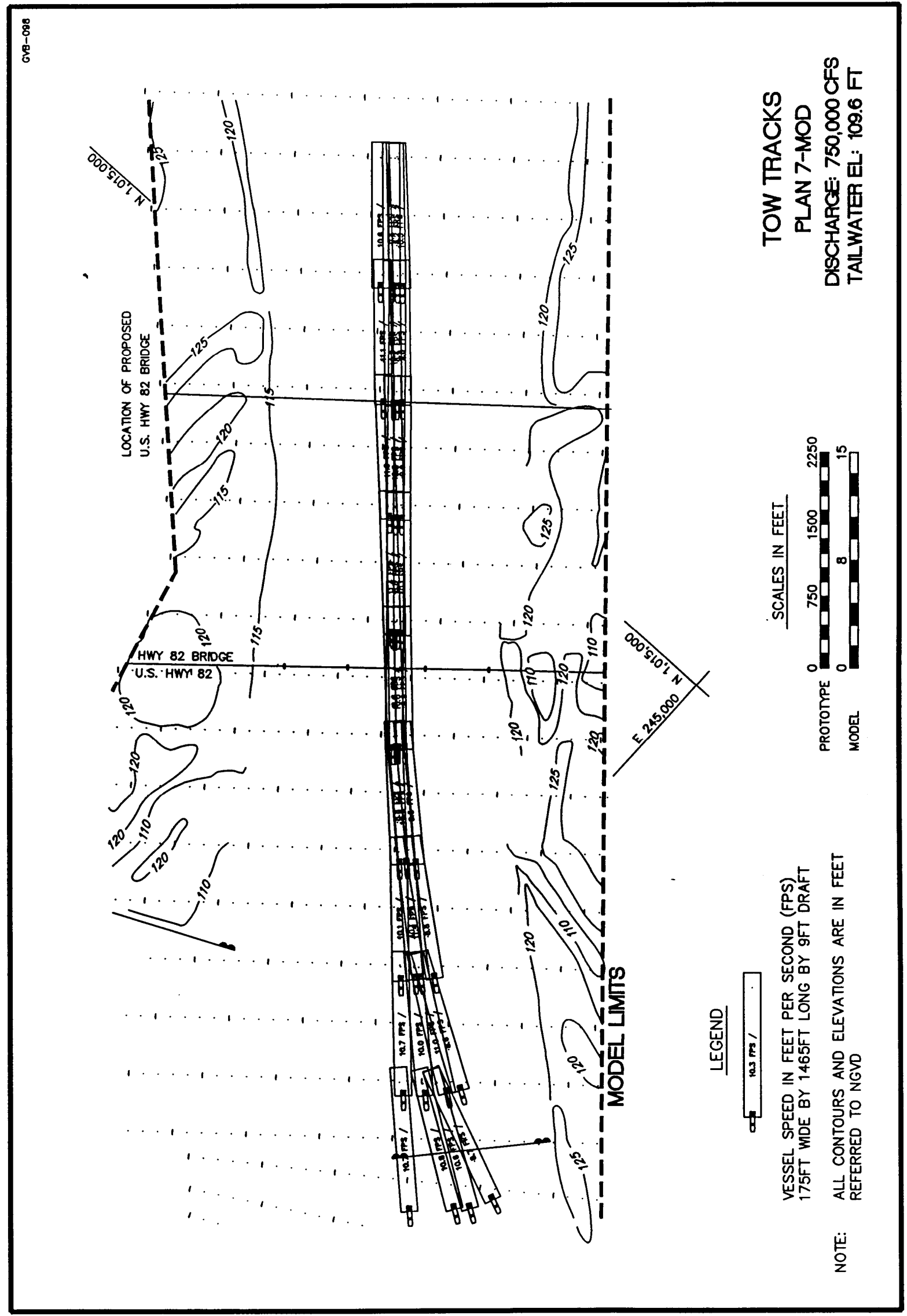

Plate 22 


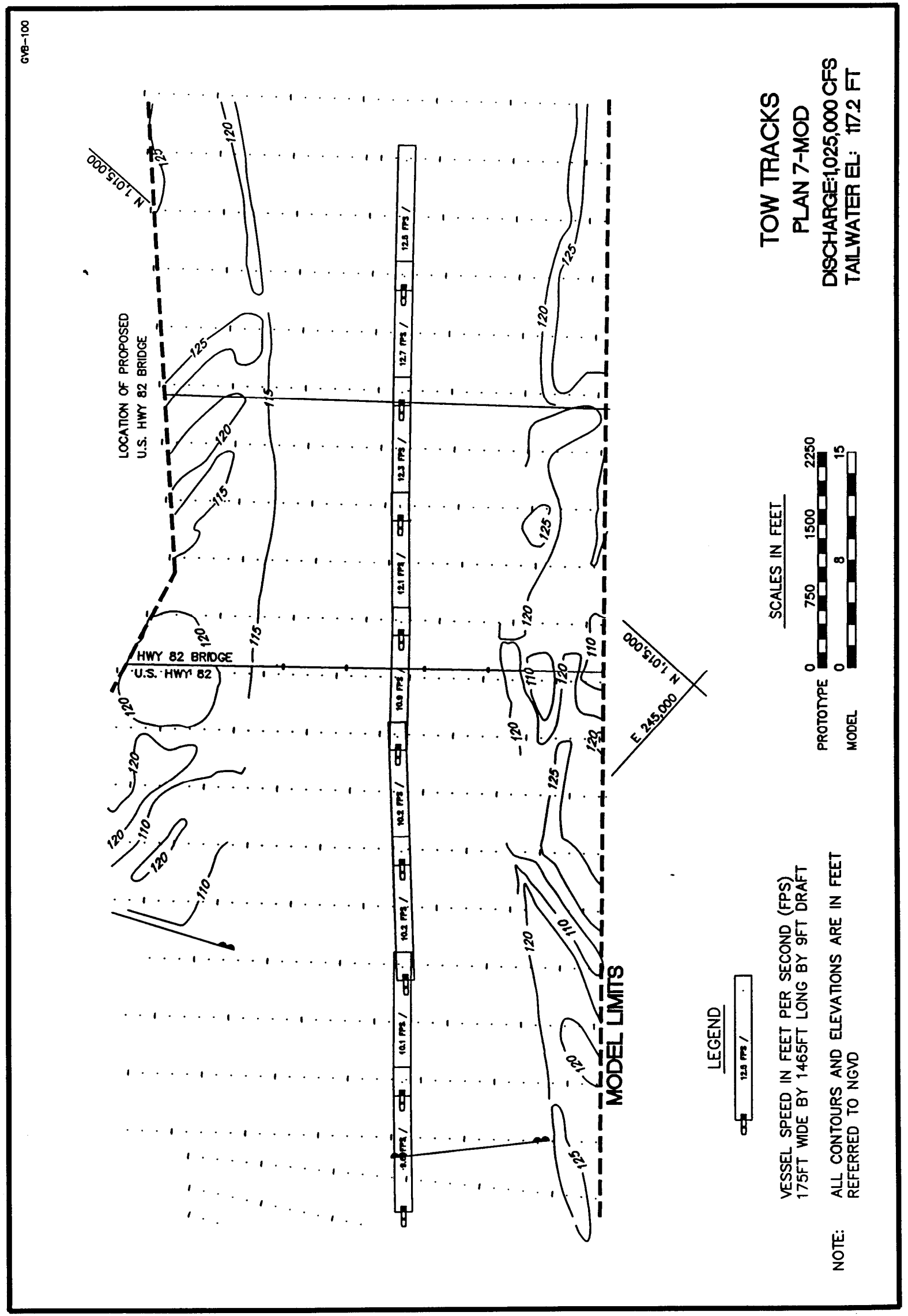

Plate 23 


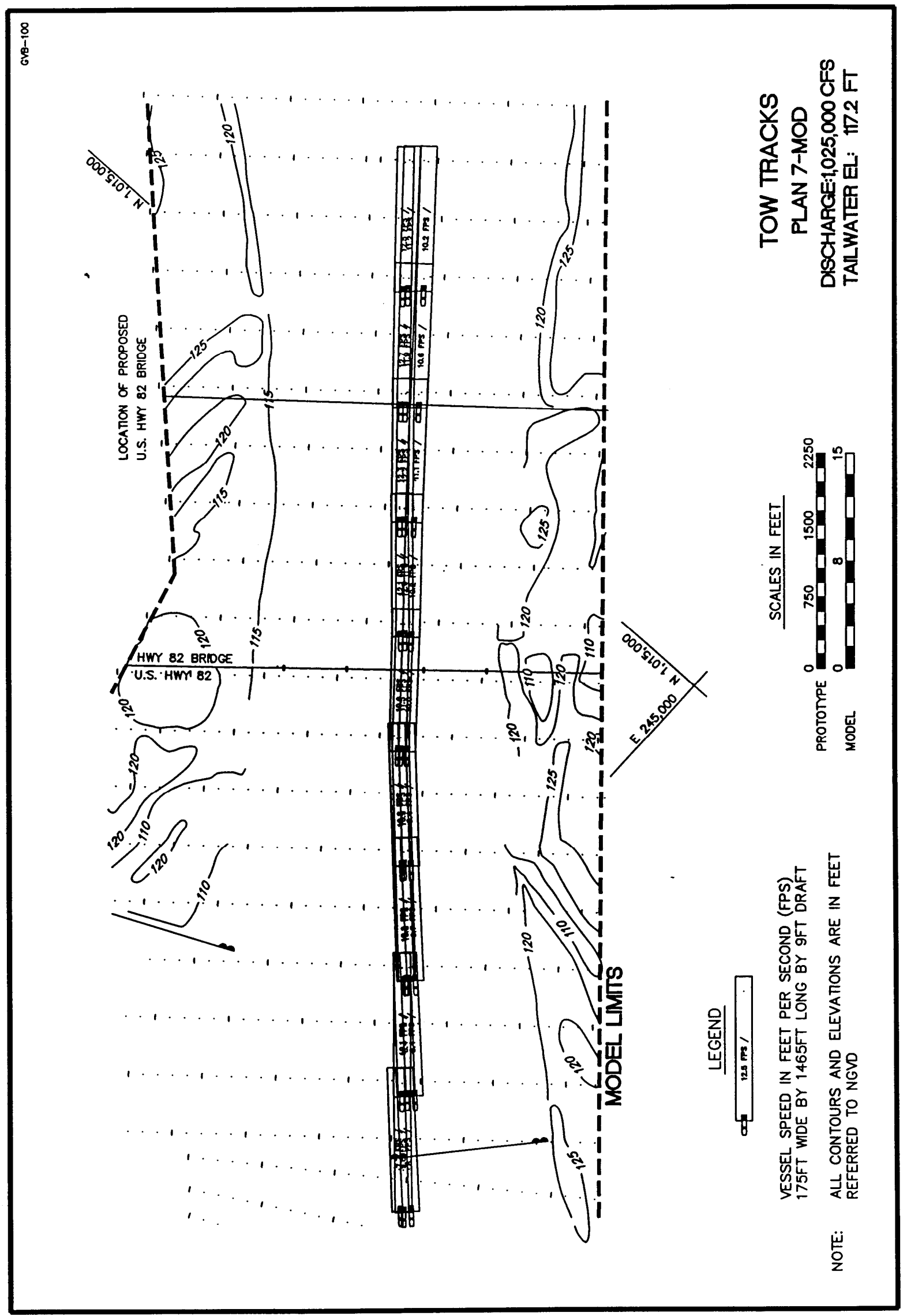

Plate 24 


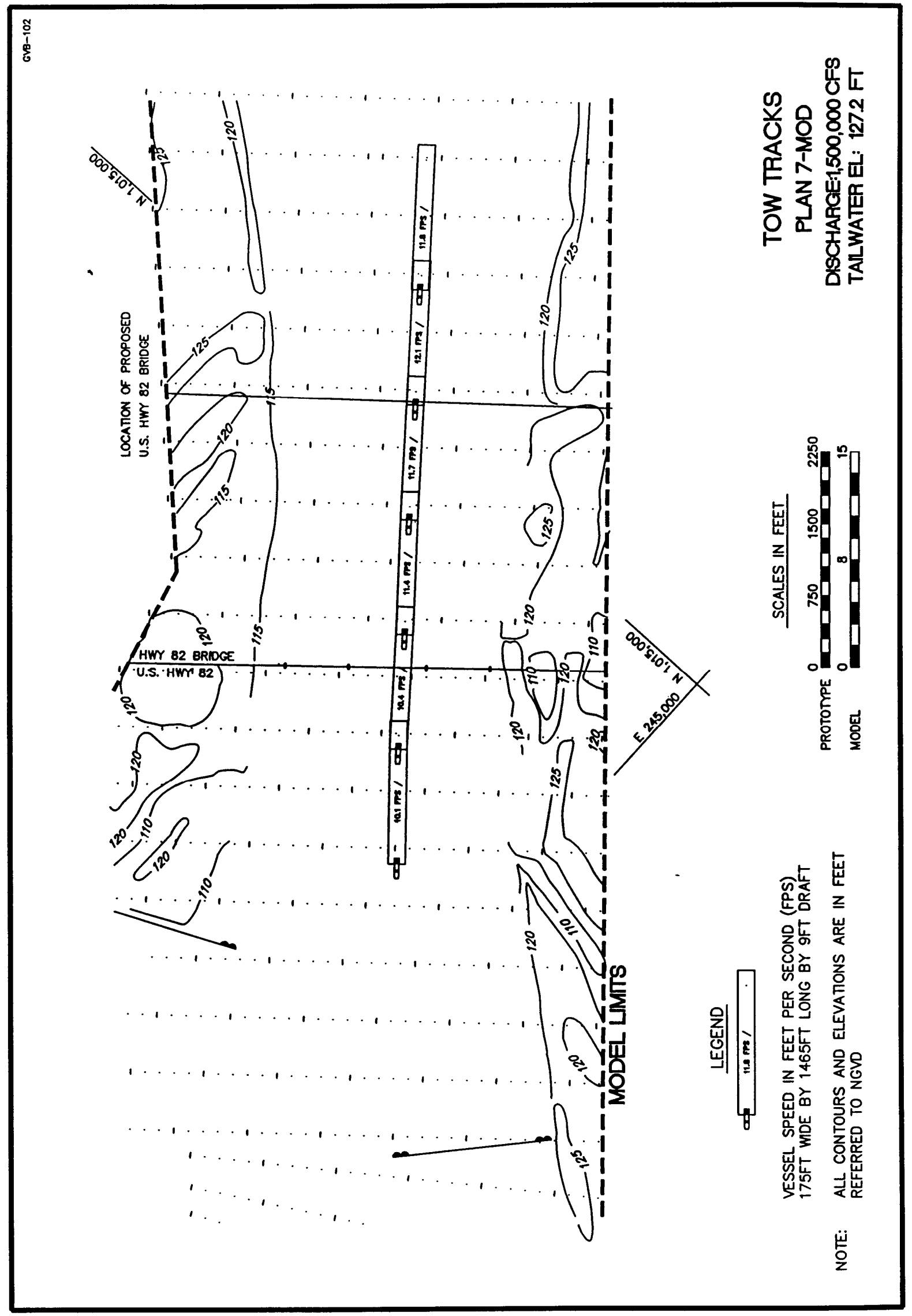

Plate 25 


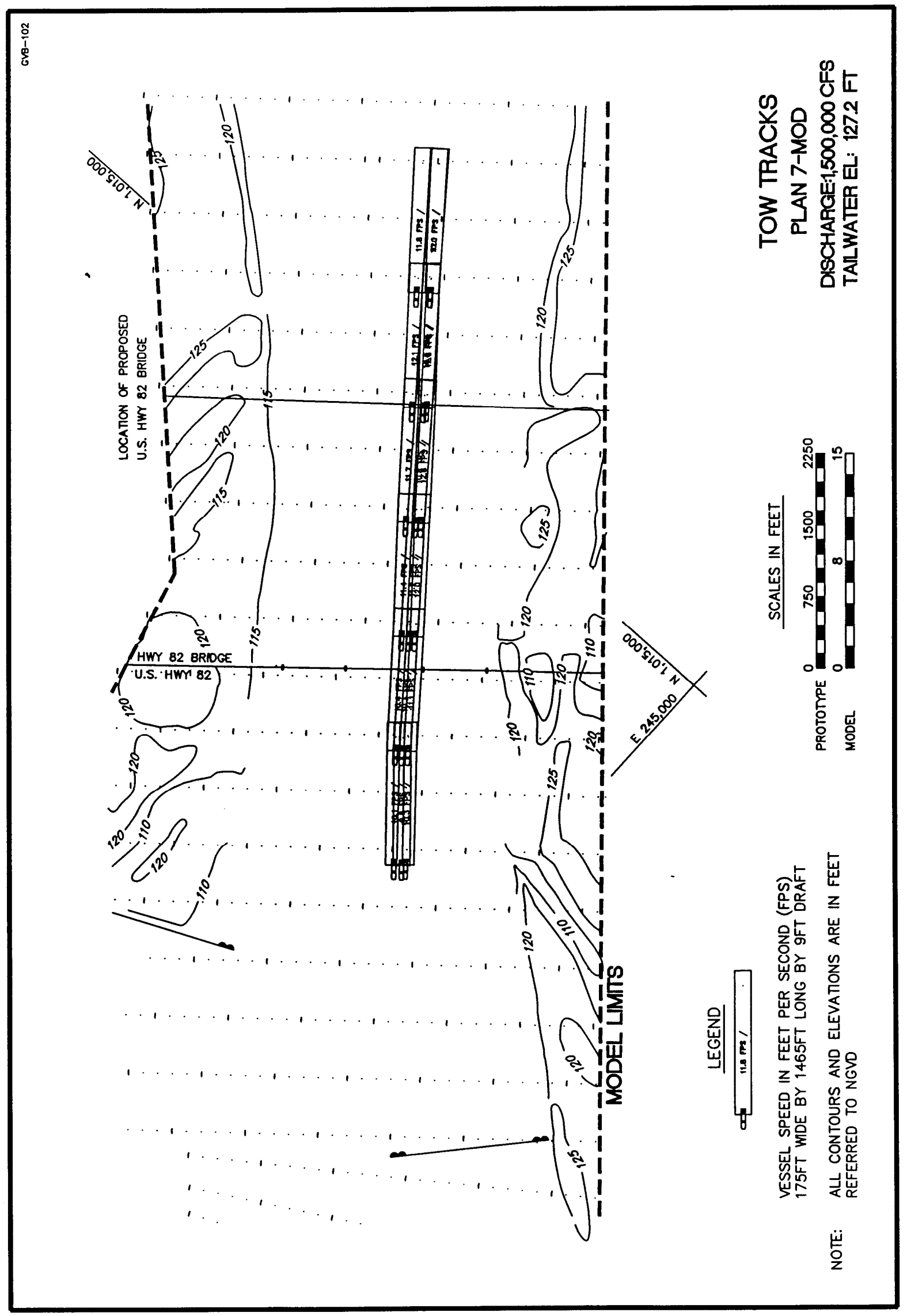

Plate 26 


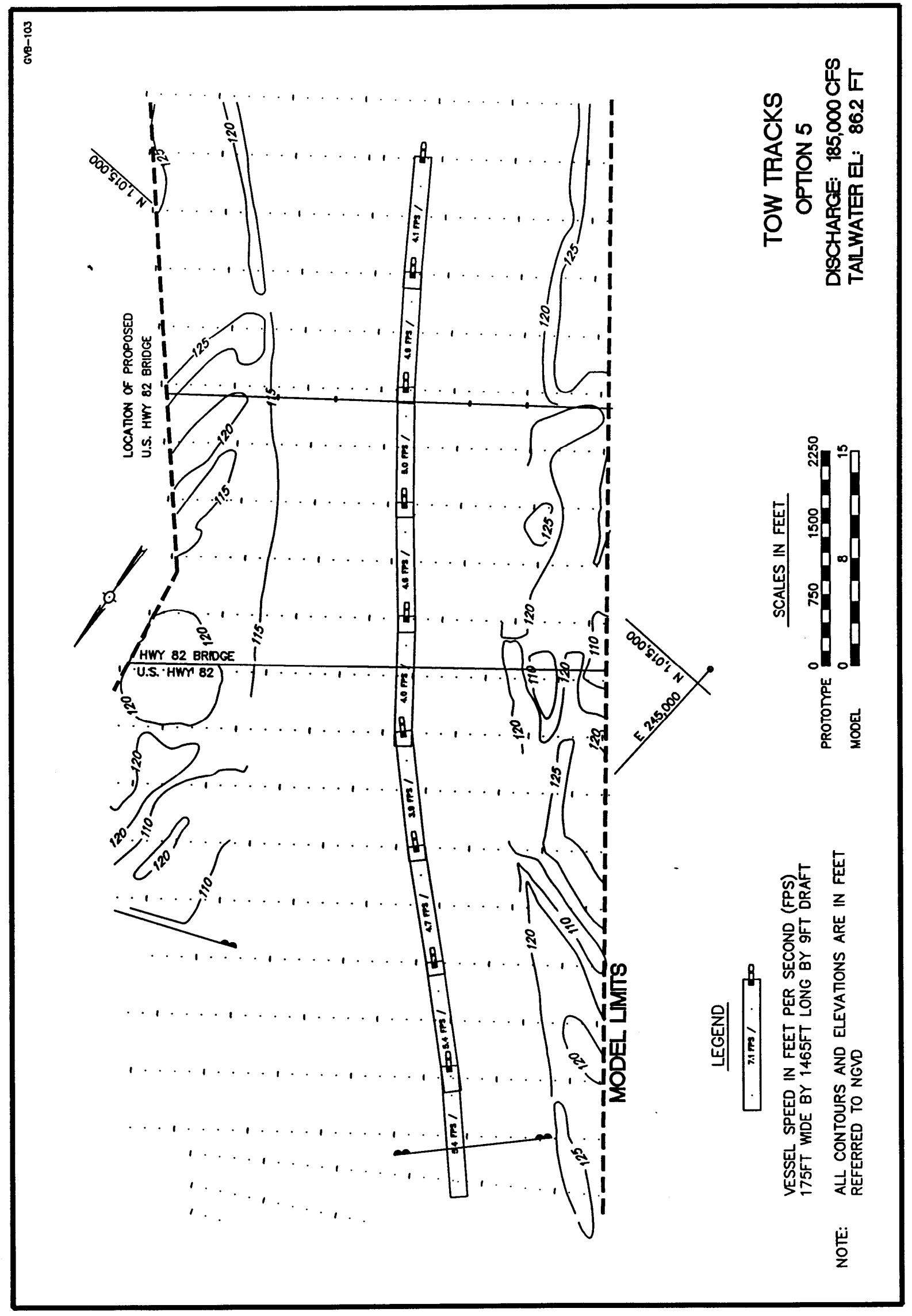




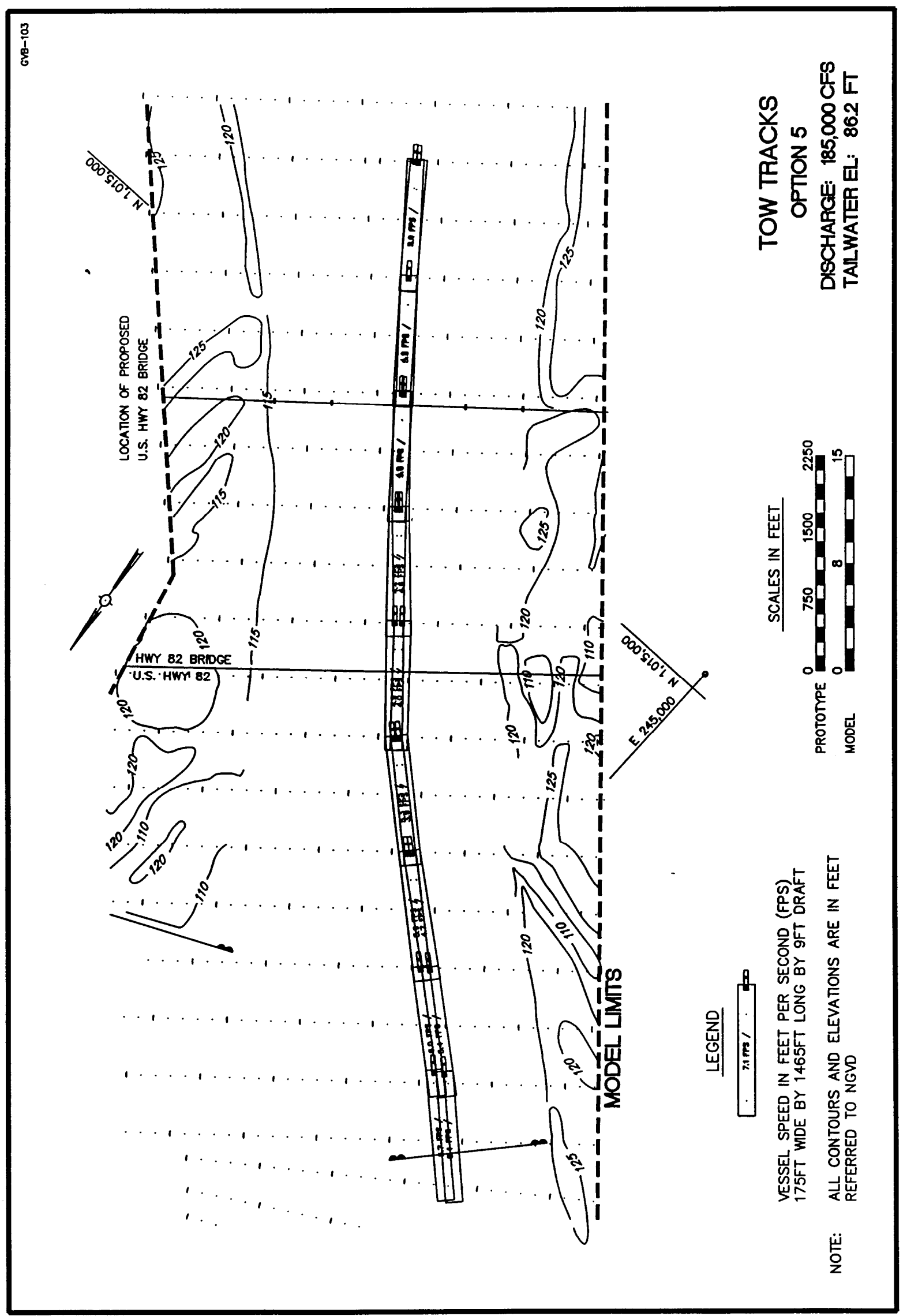

Plate 28 


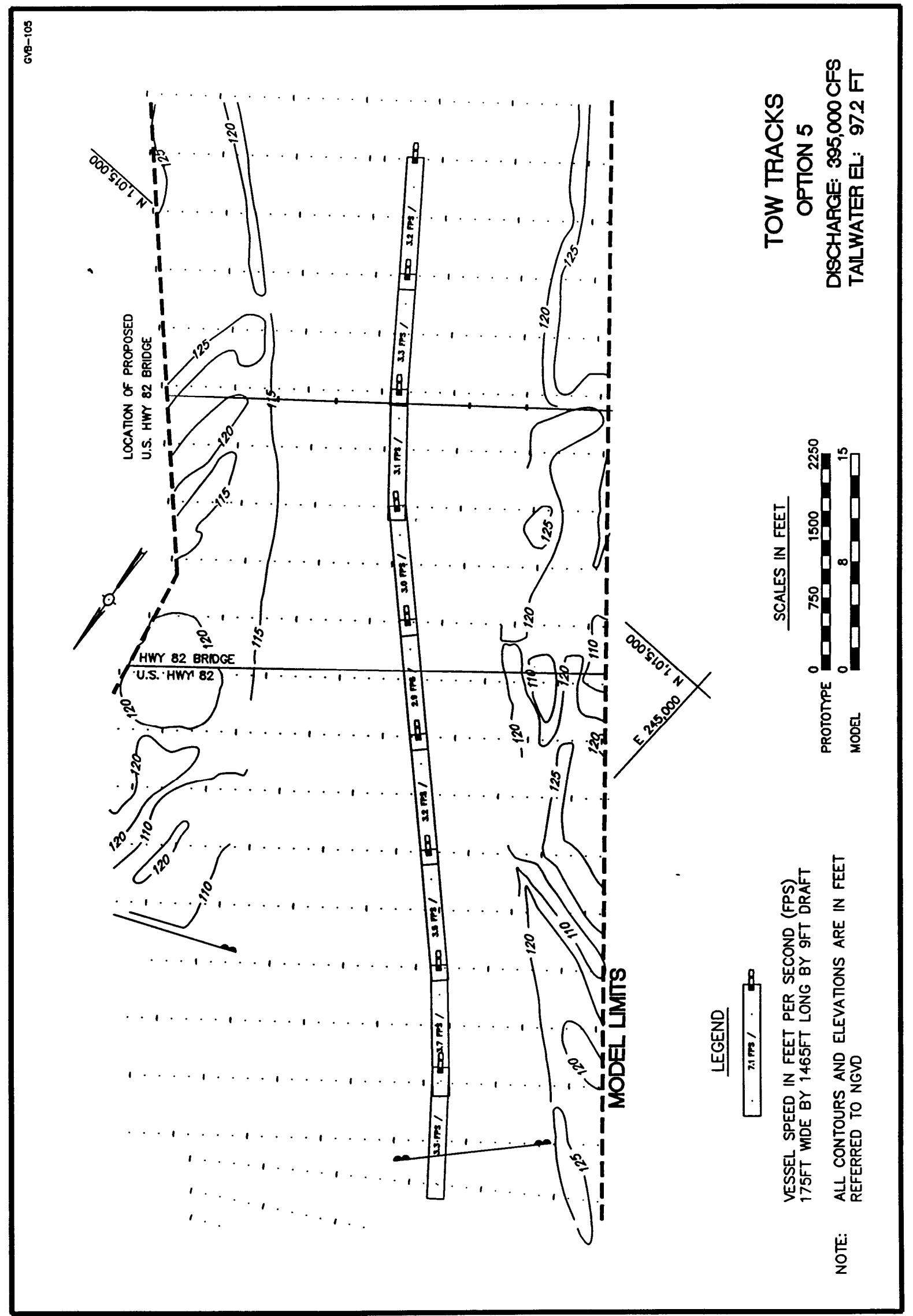

Plate 29 


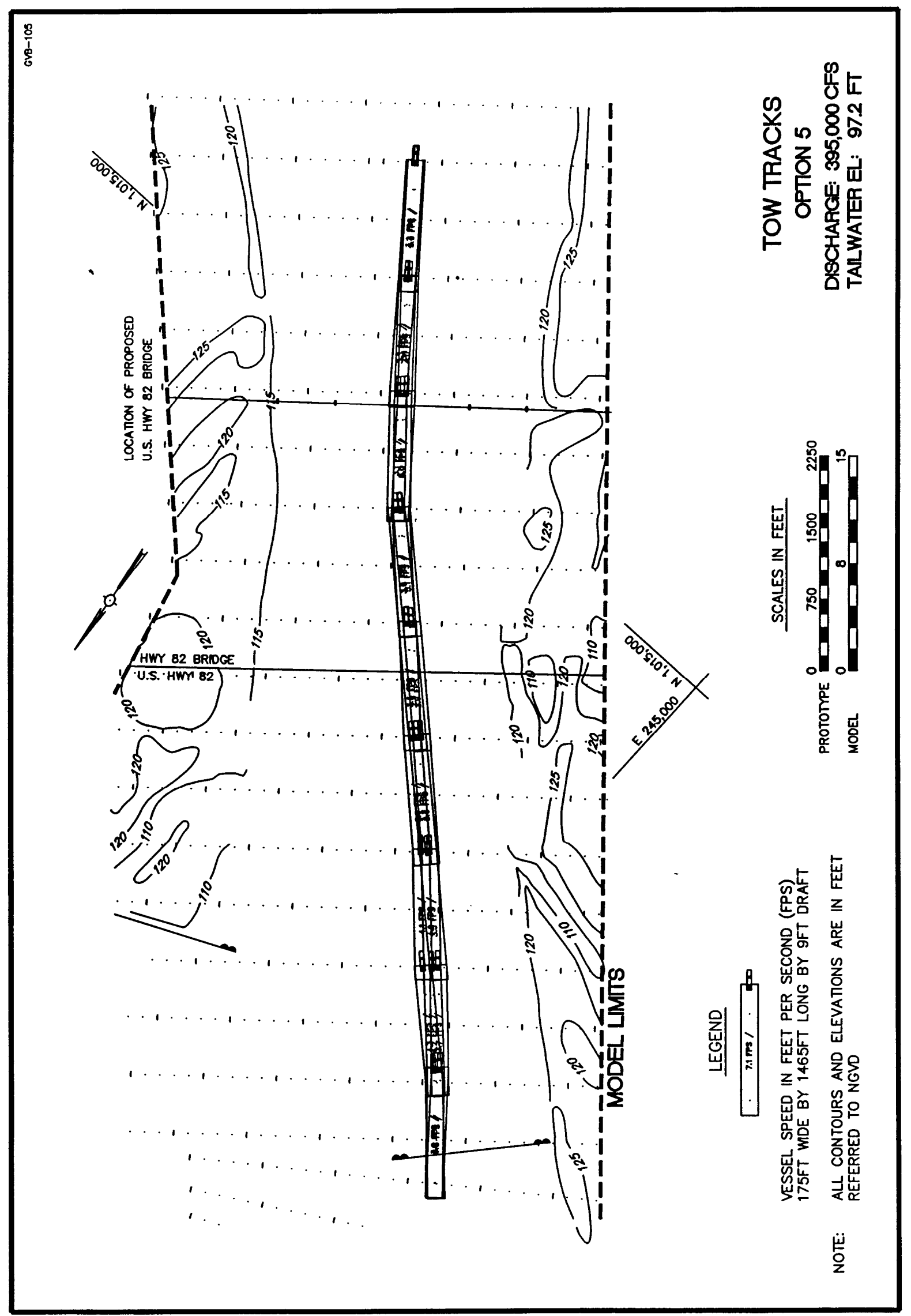

Plate 30 


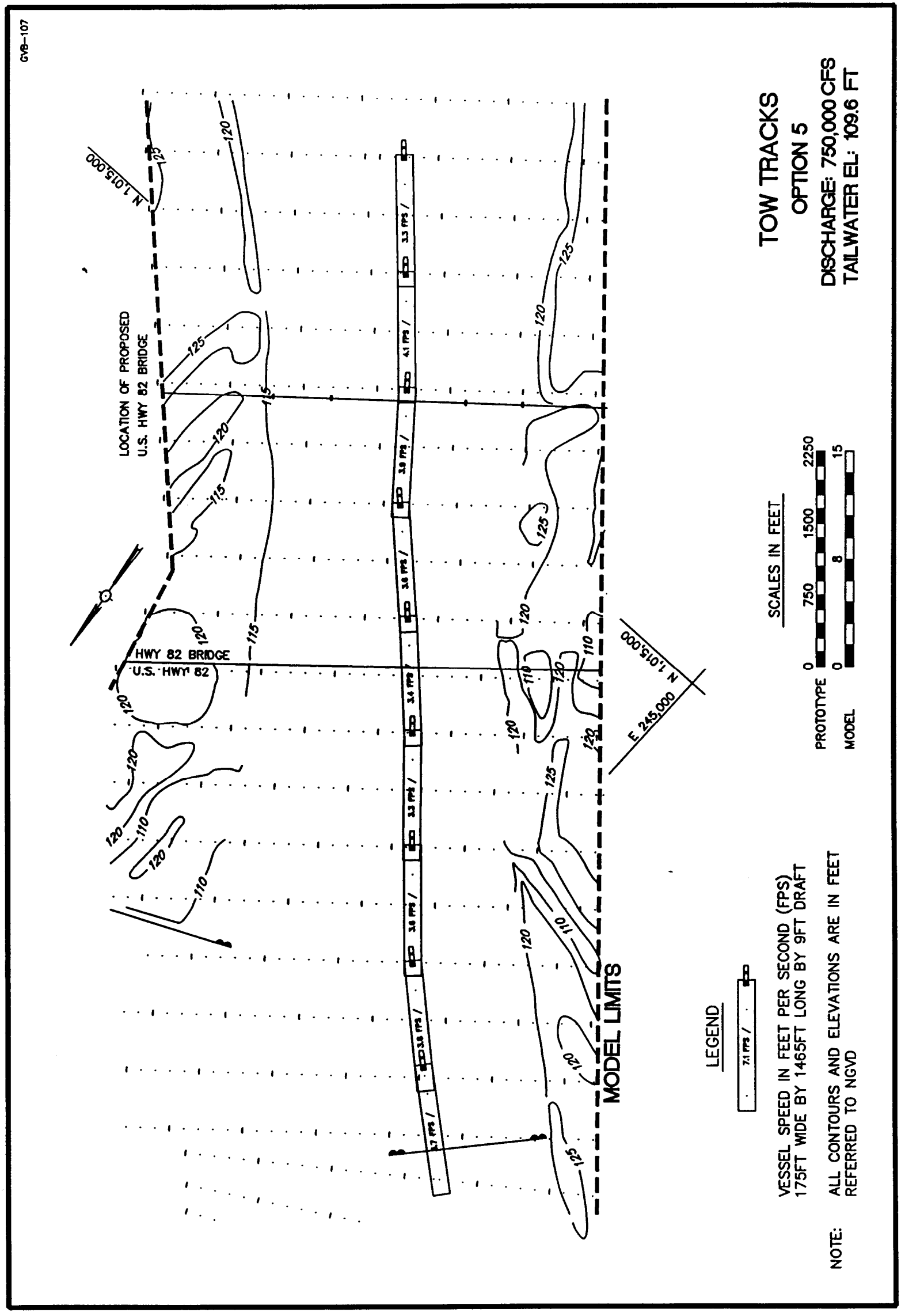

PLate 31 


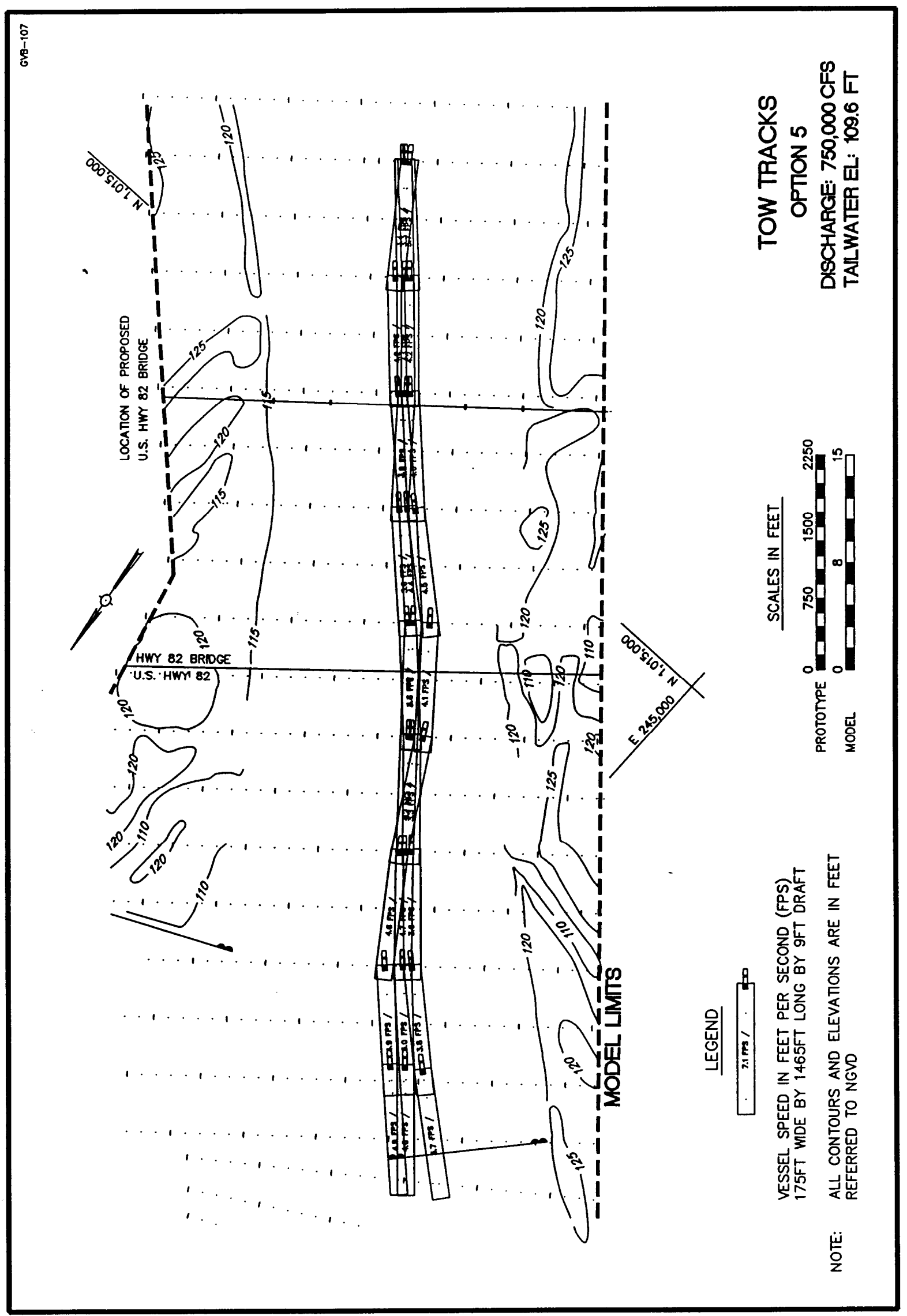

PLate 32 


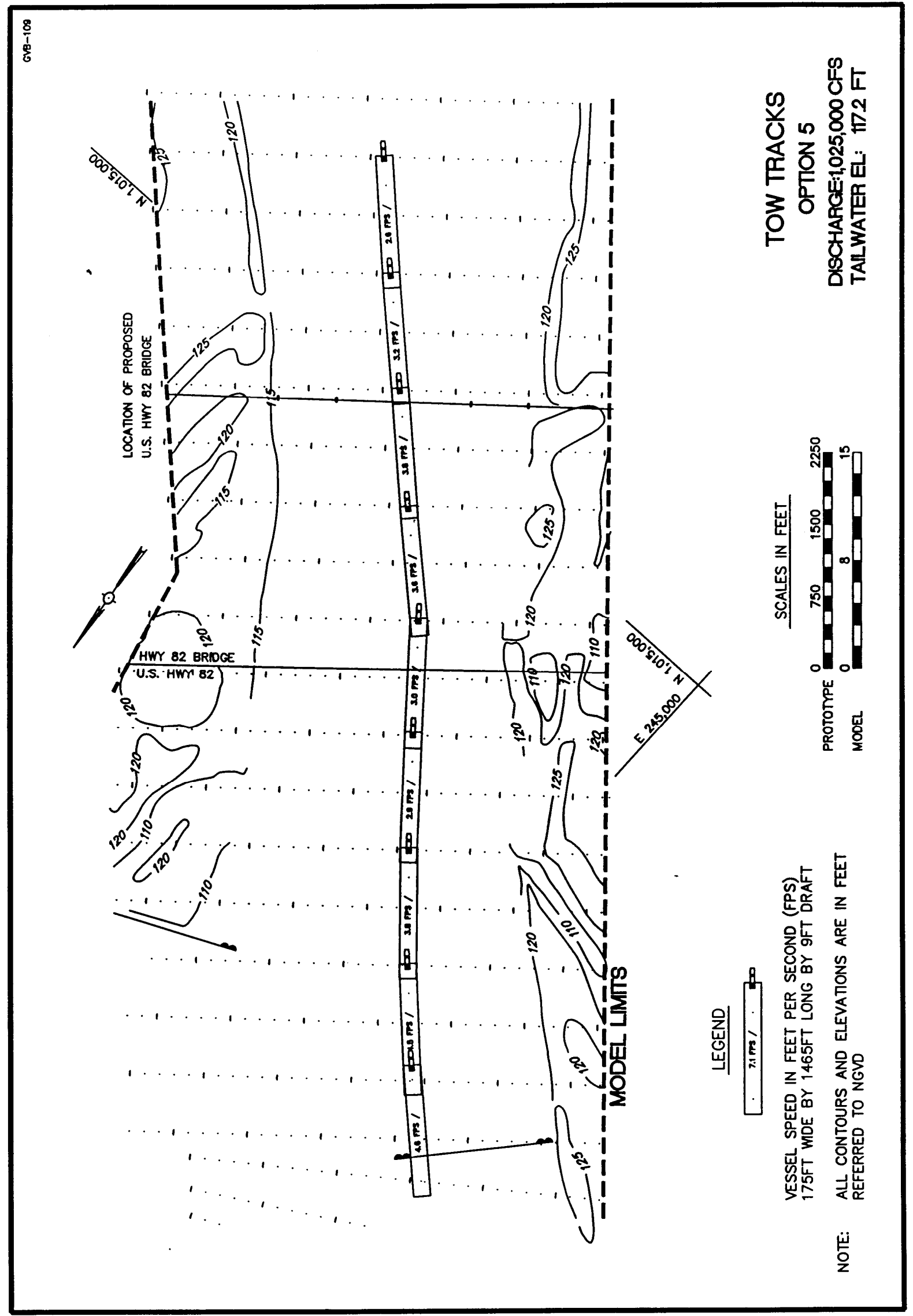

Plate 33 


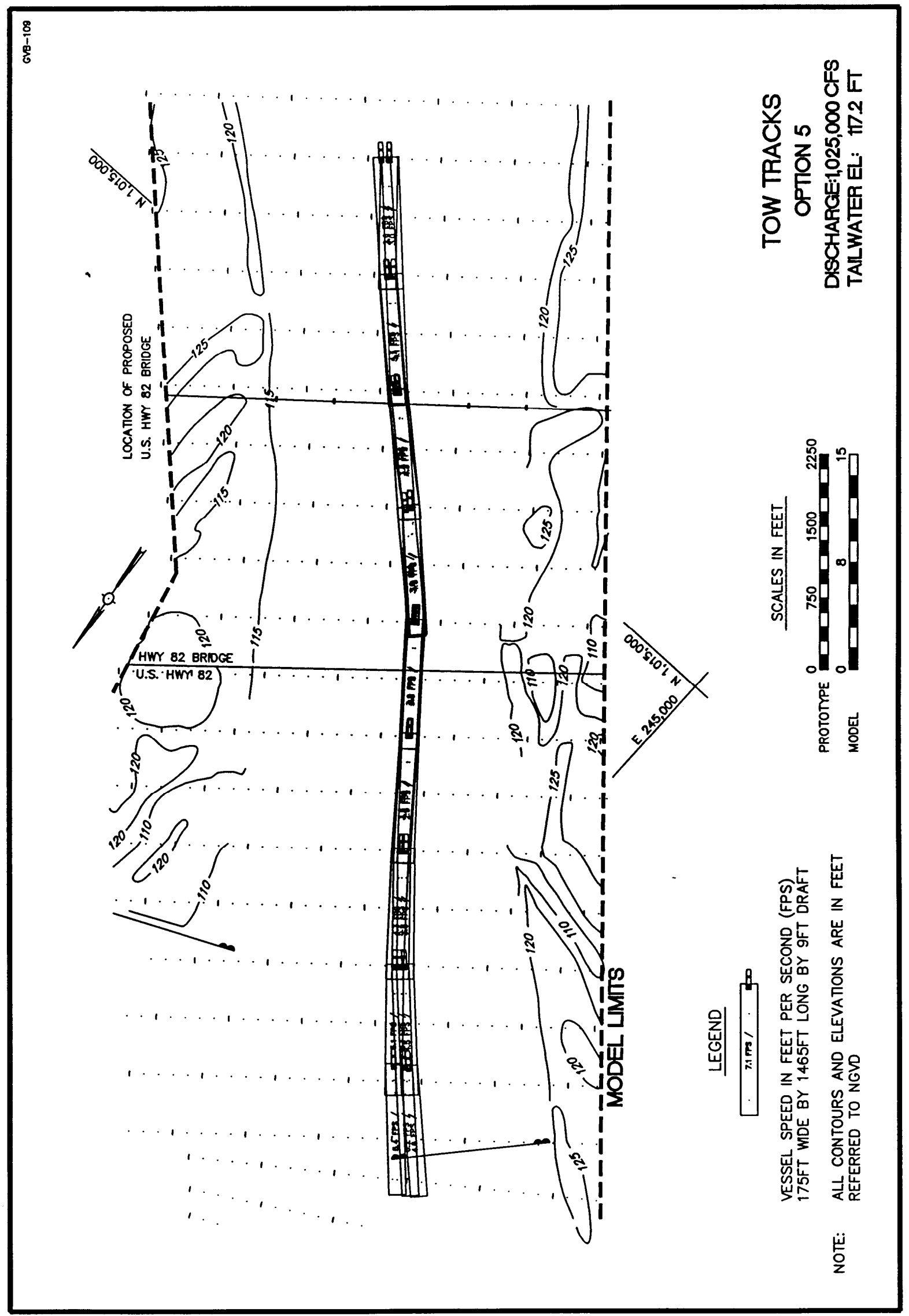

Plate 34 


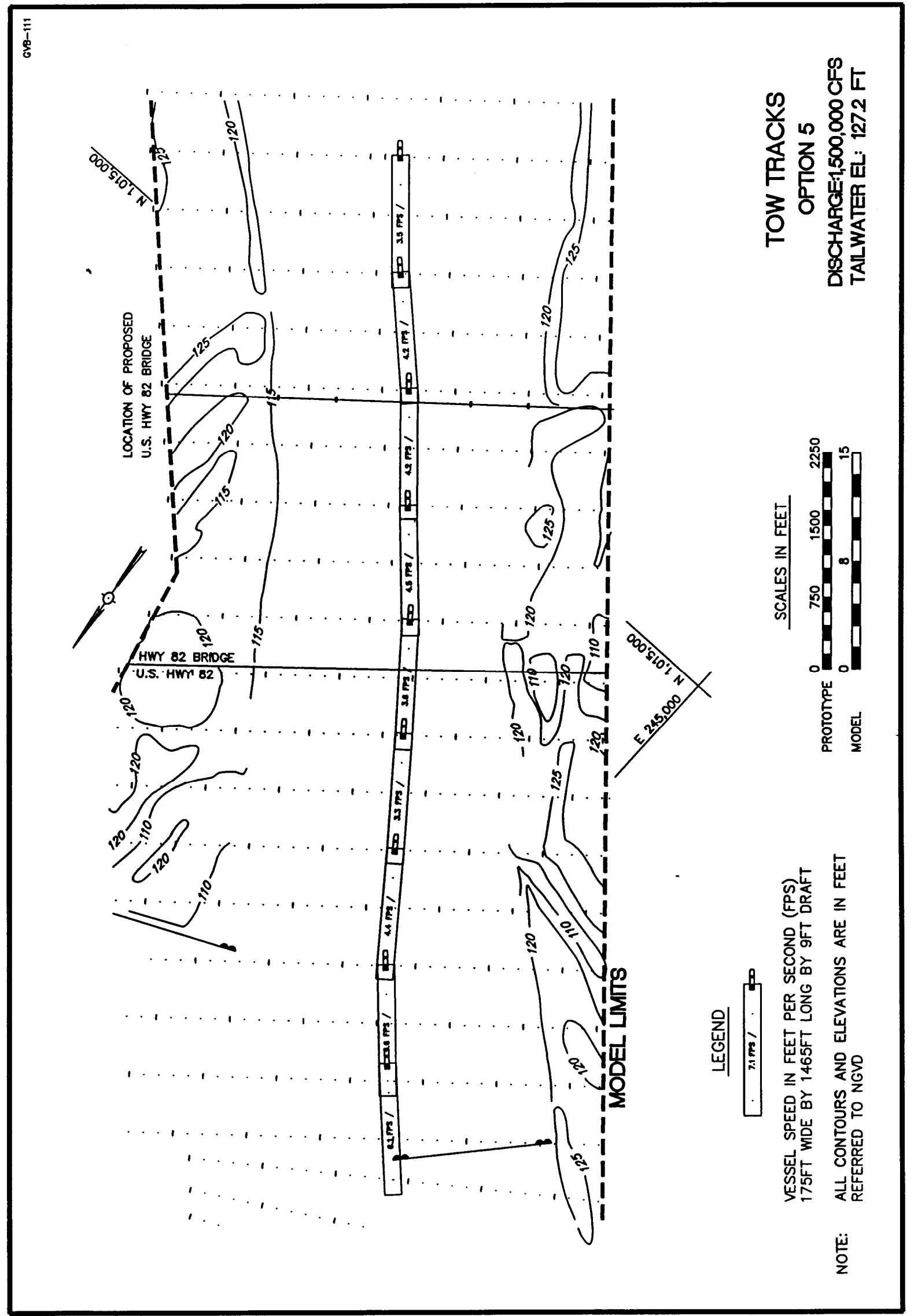




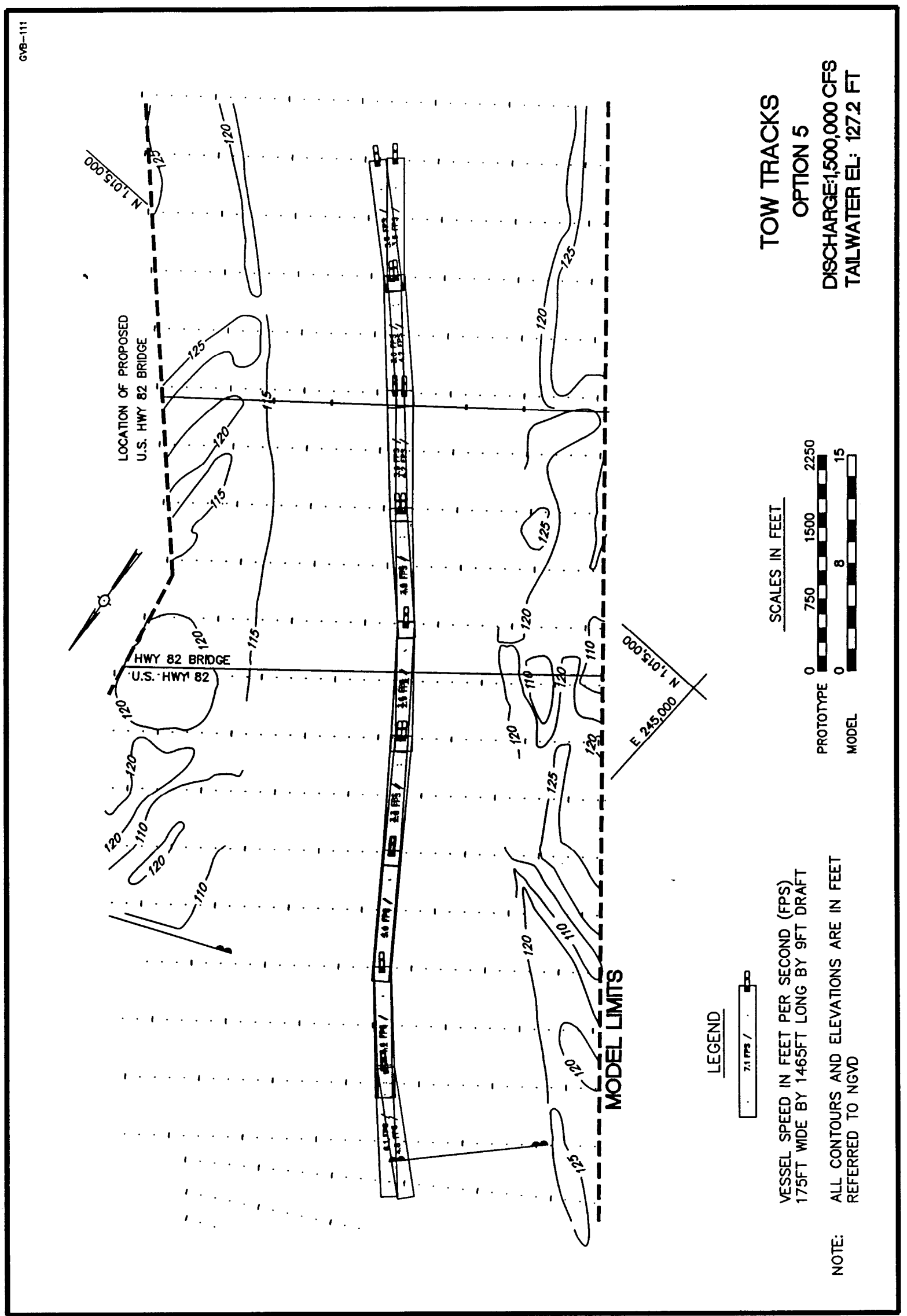

Plate 36 


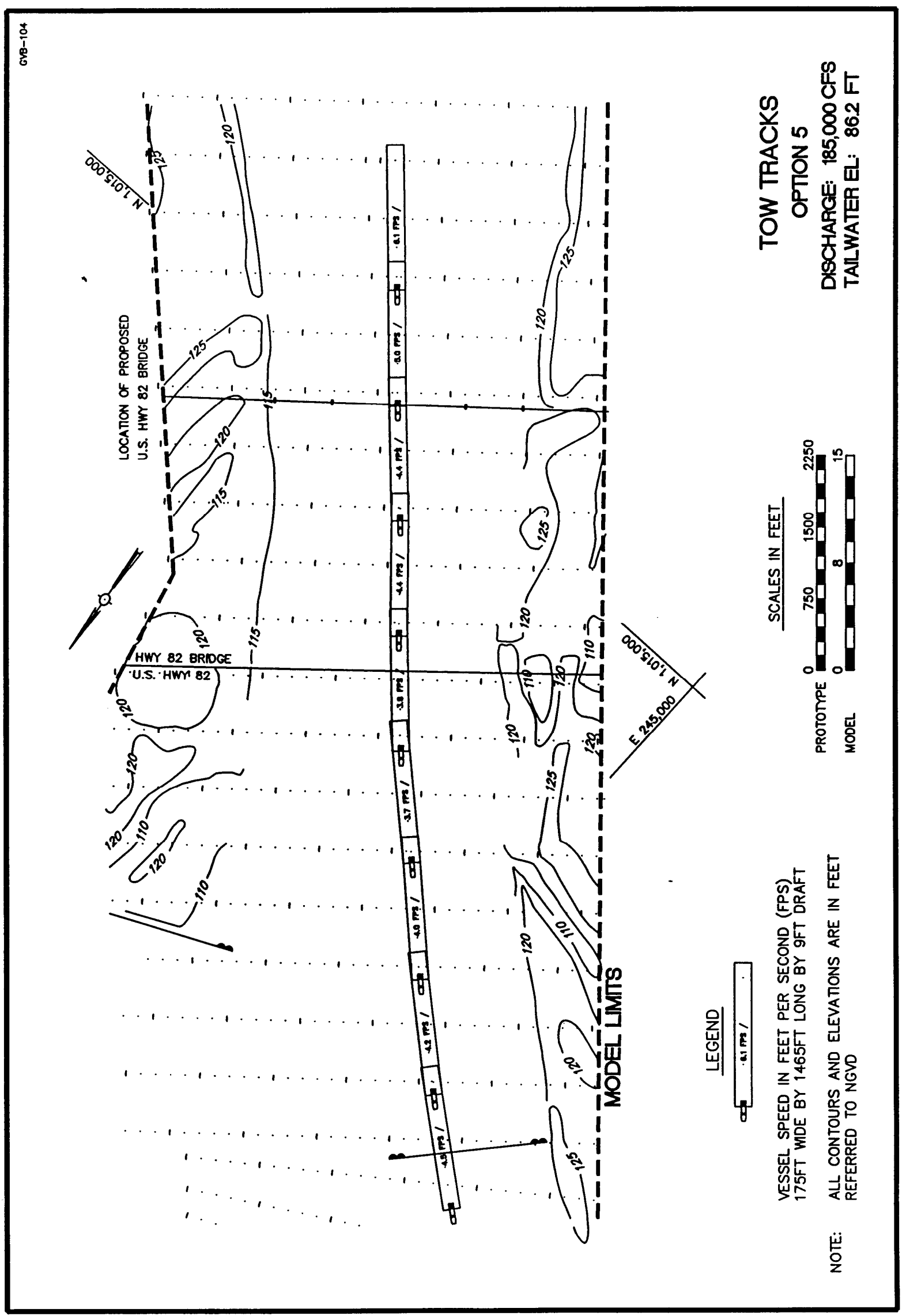

Plate 37 


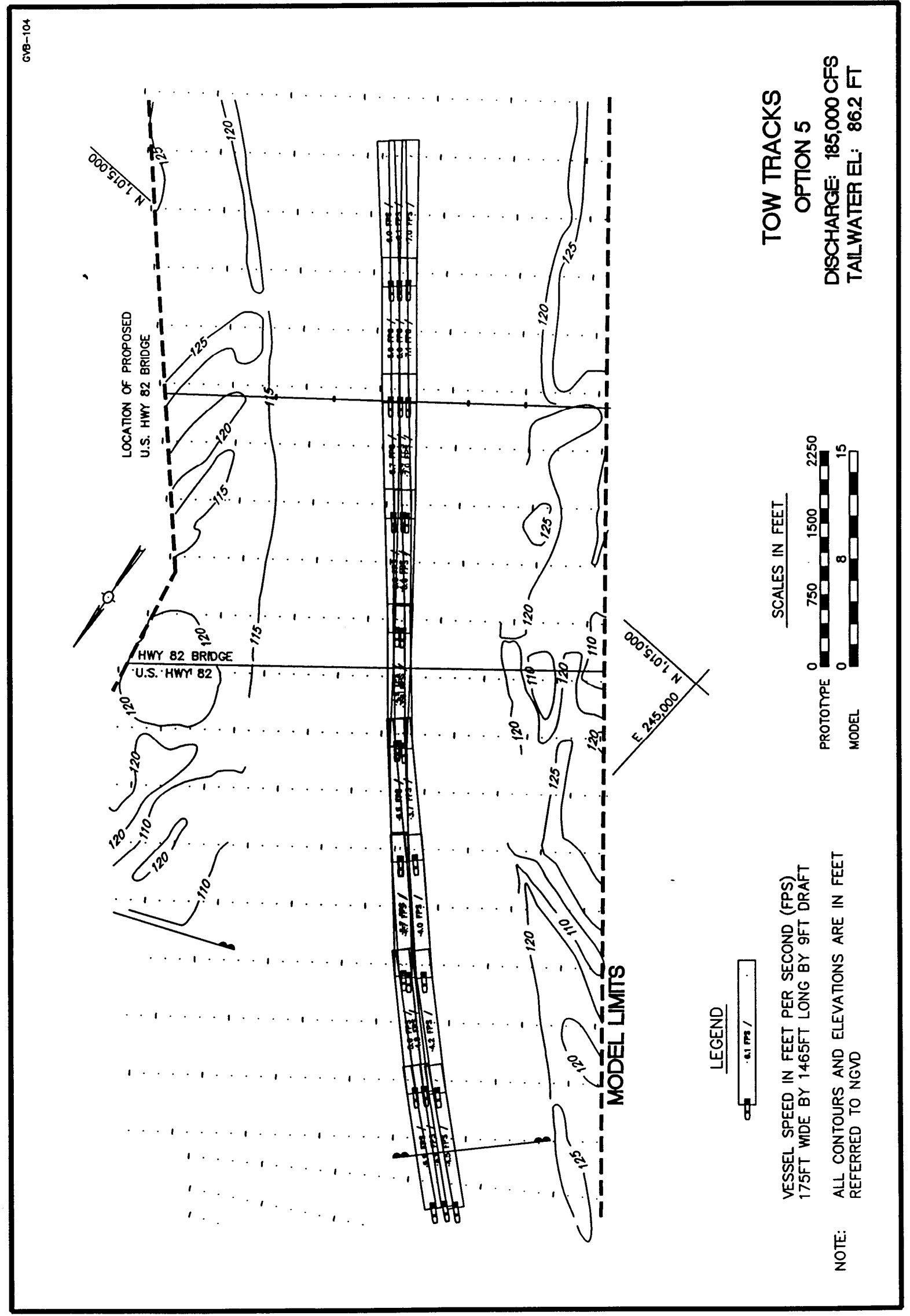

Plate 38 


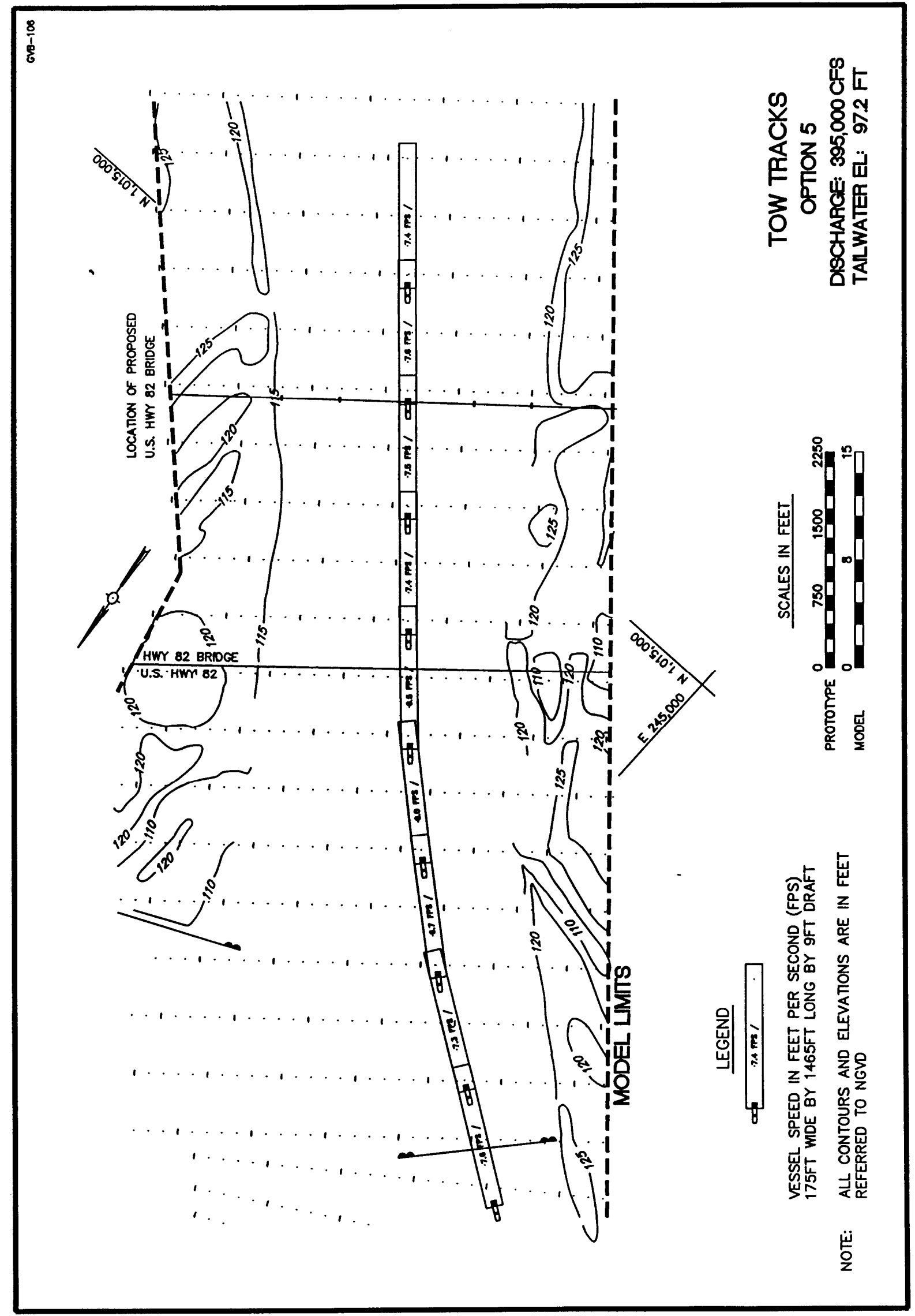

Plate 39 


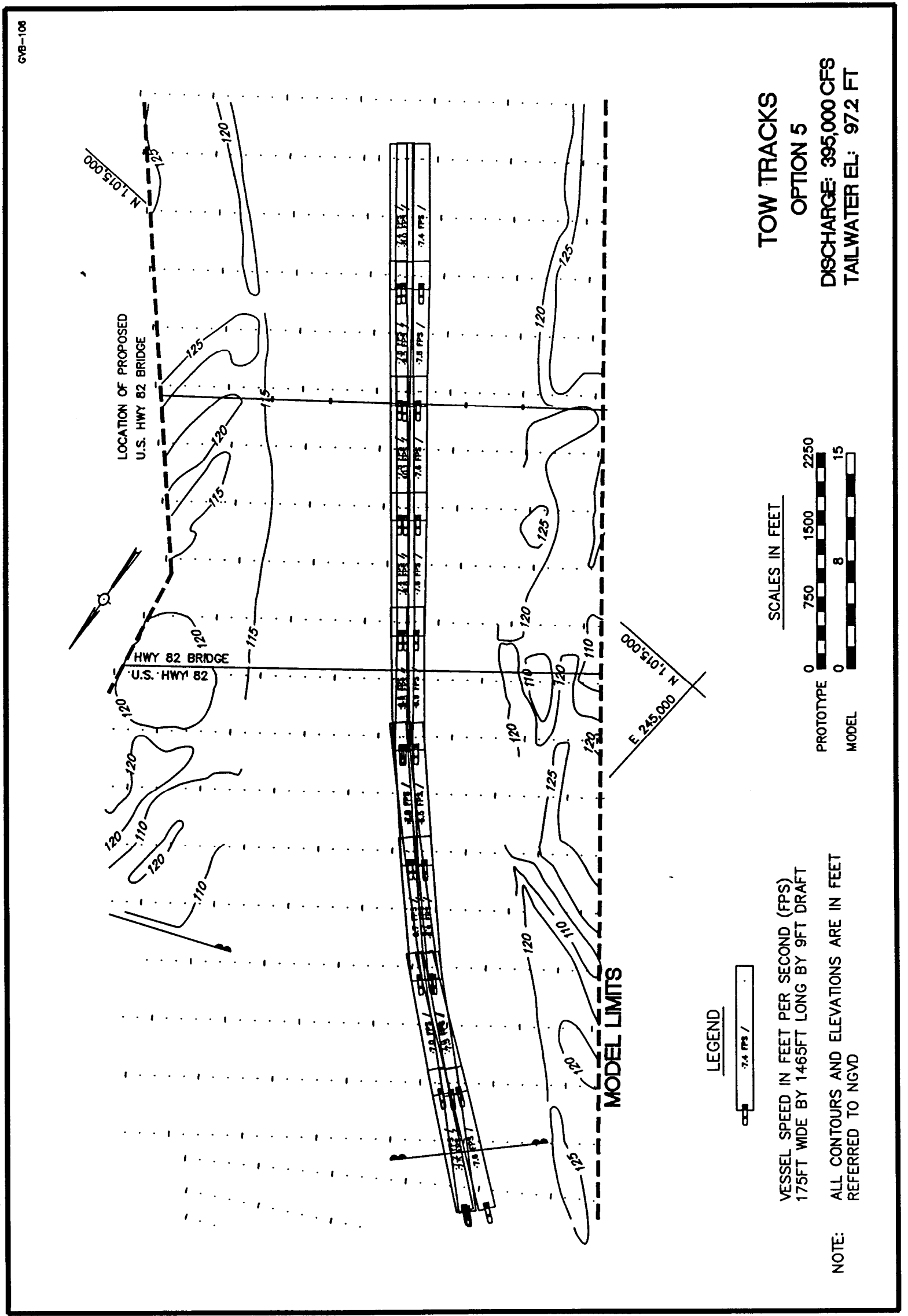

Plate 40 


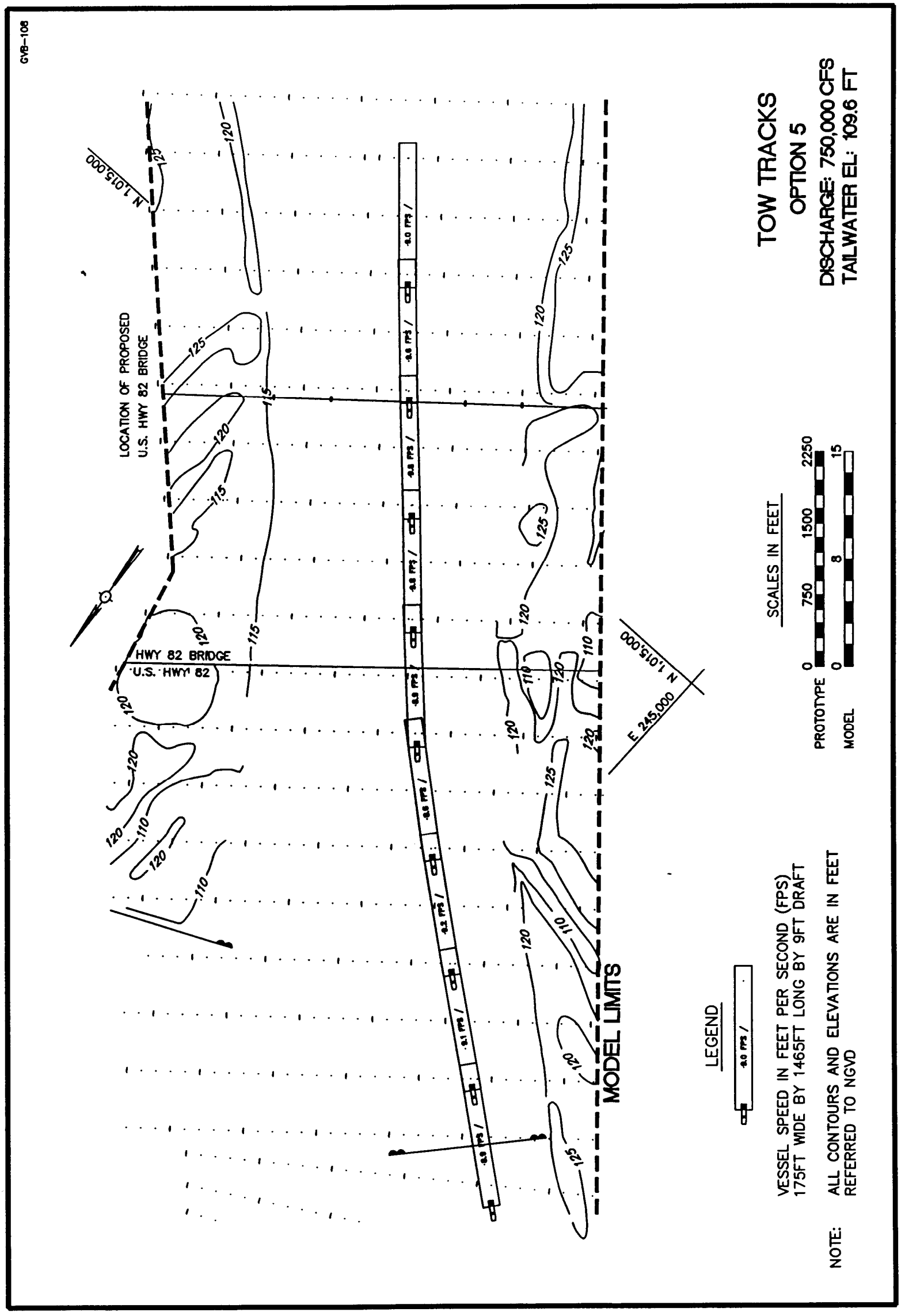

Plate 41 


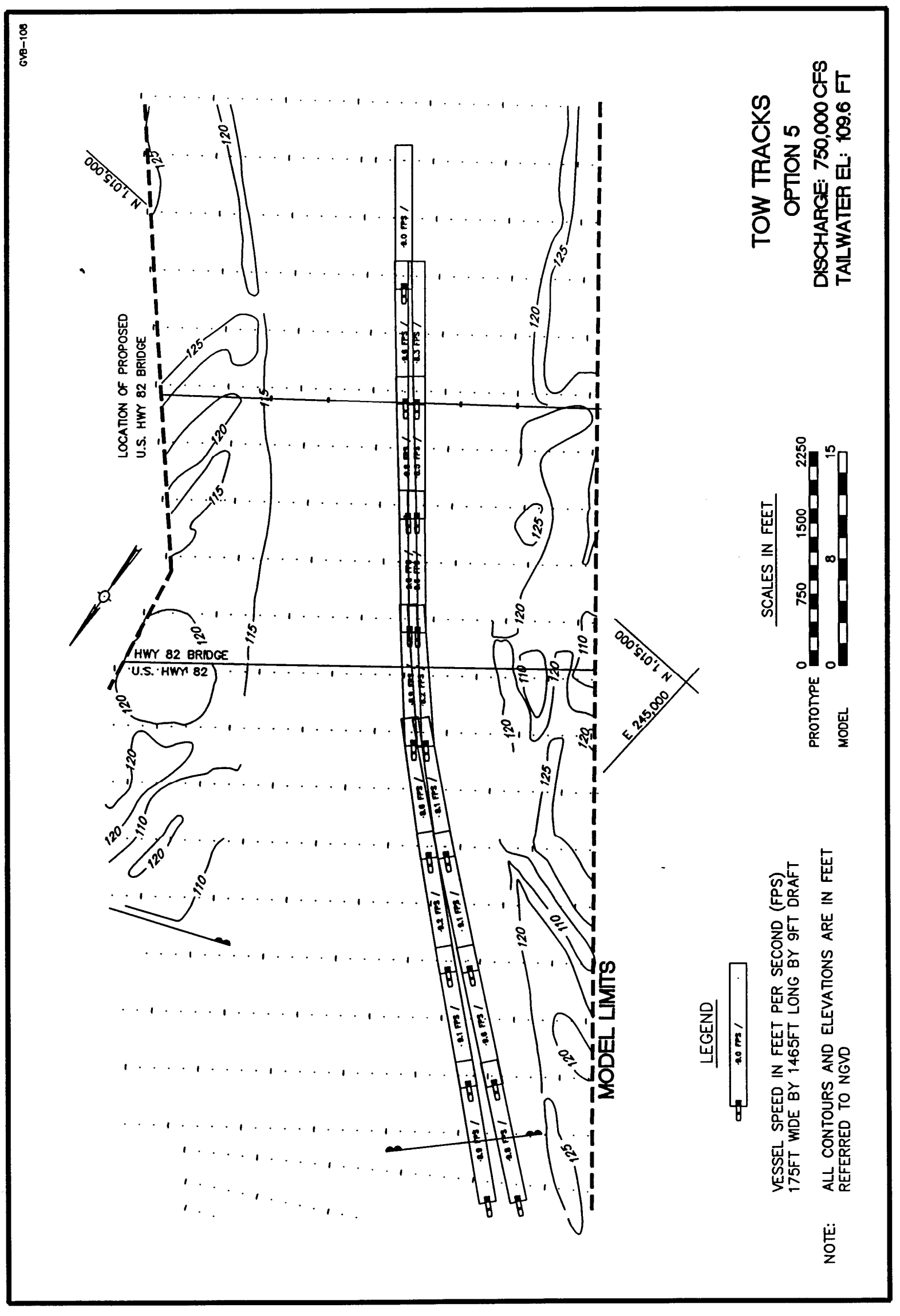

Plate 42 


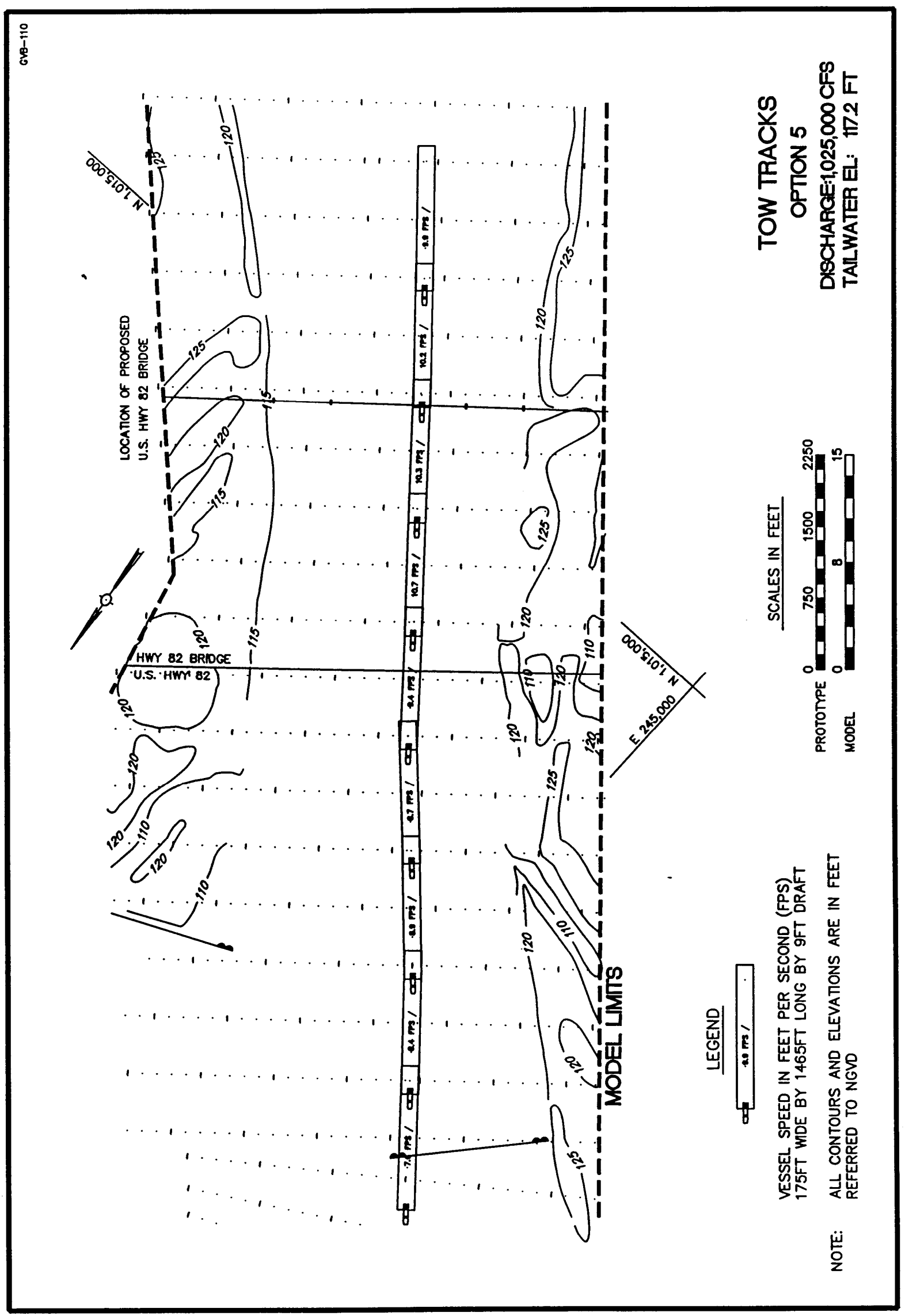

Plate 43 


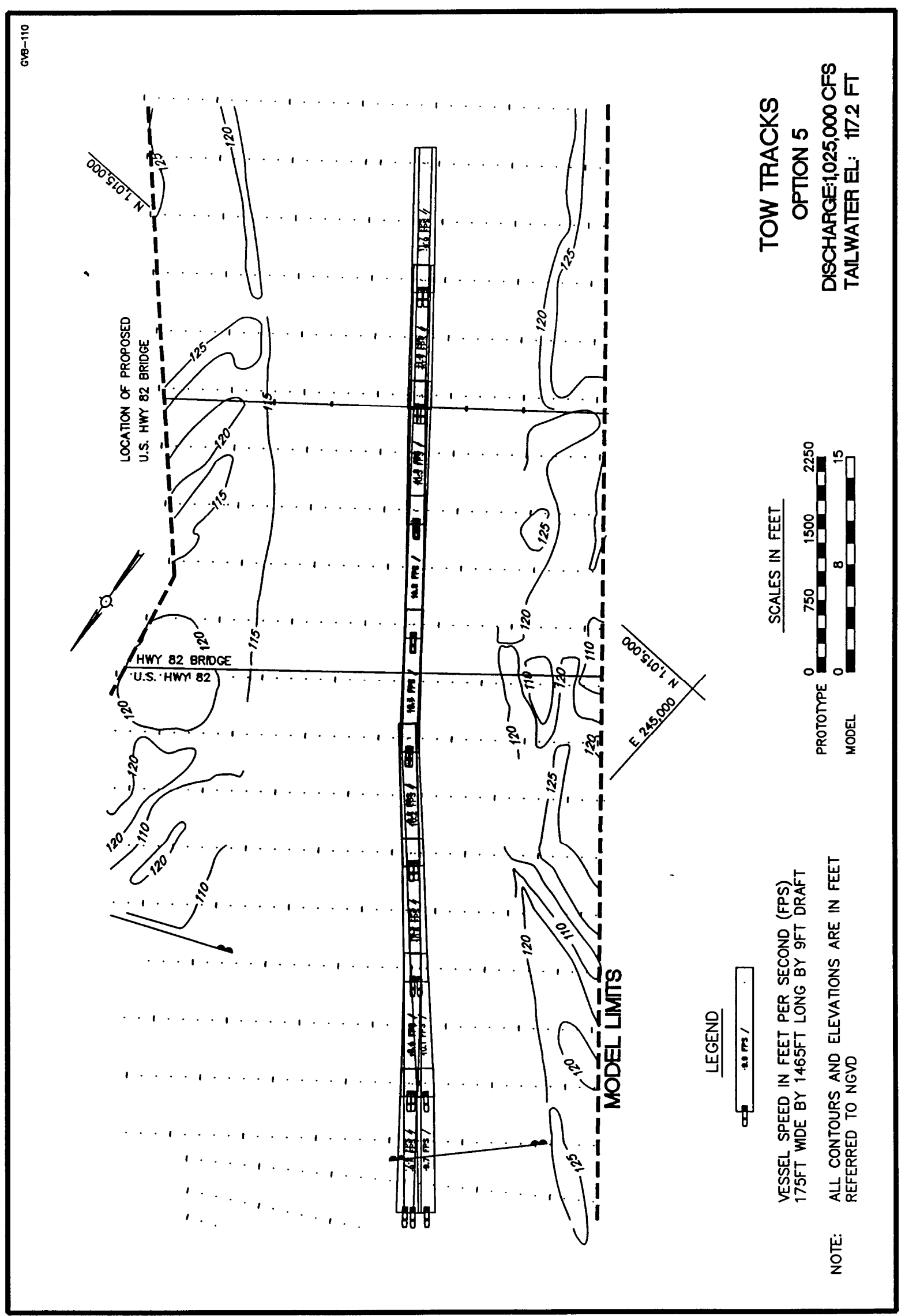

Plate 44 


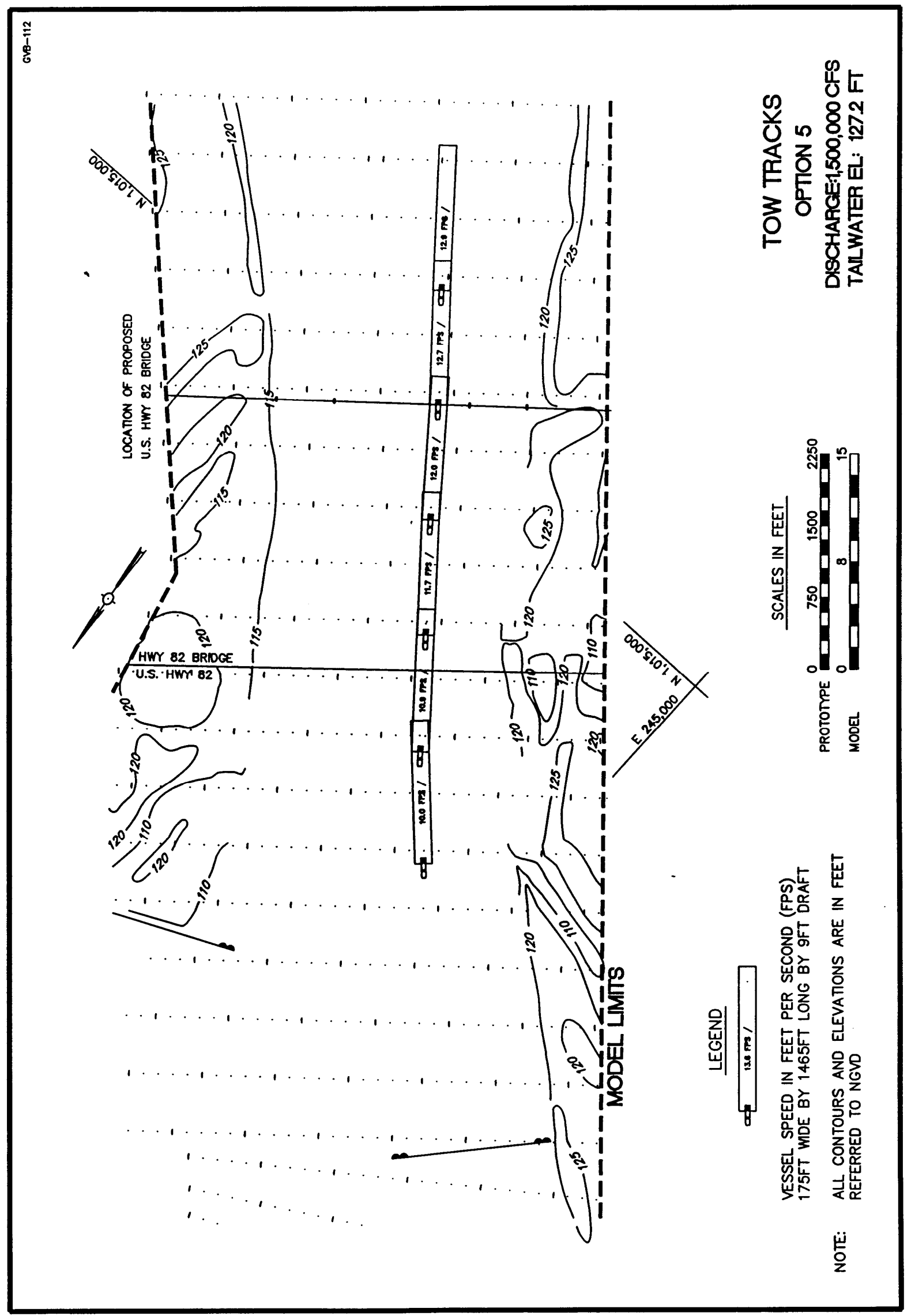

Plate 45 


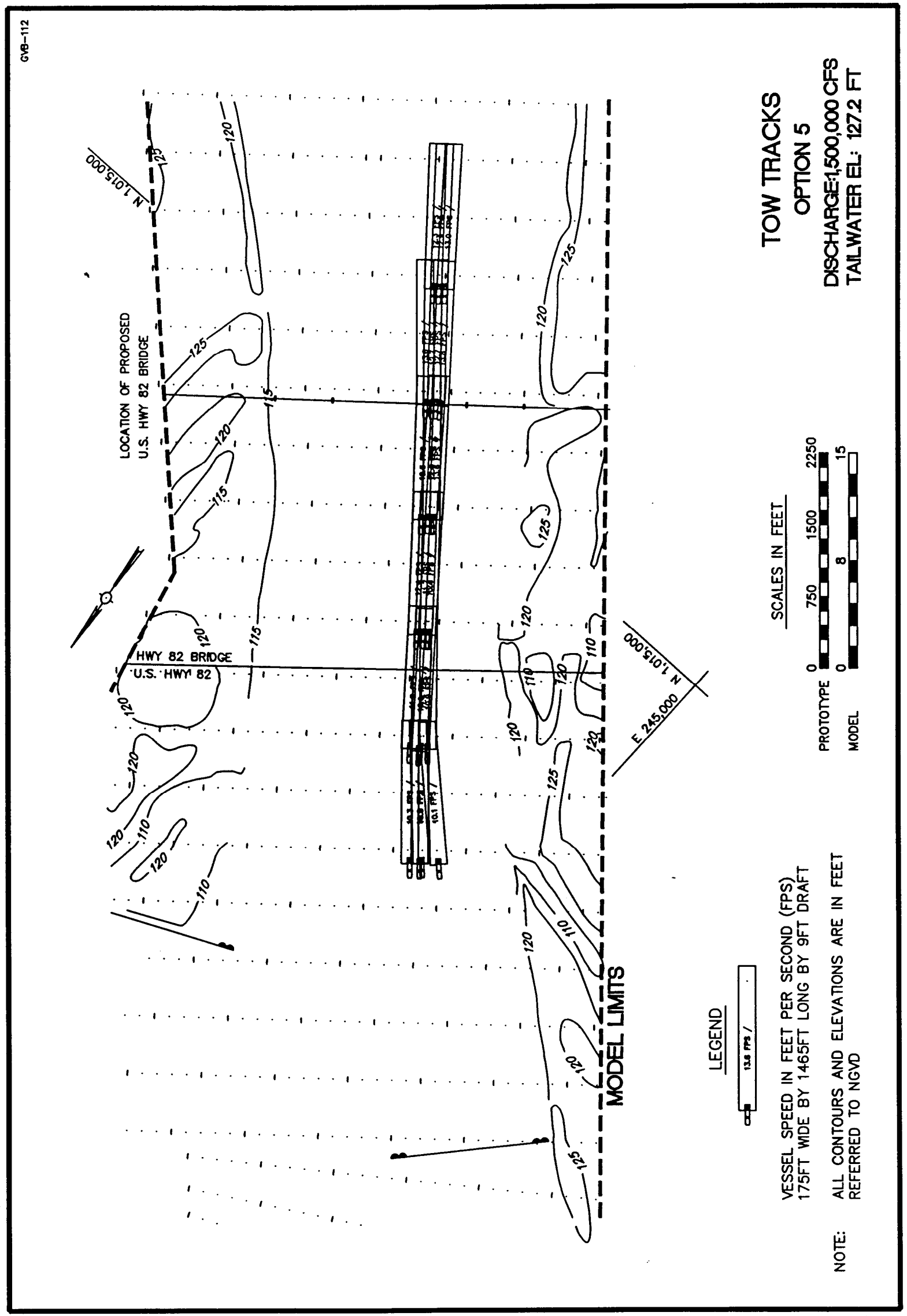

Plate 46 


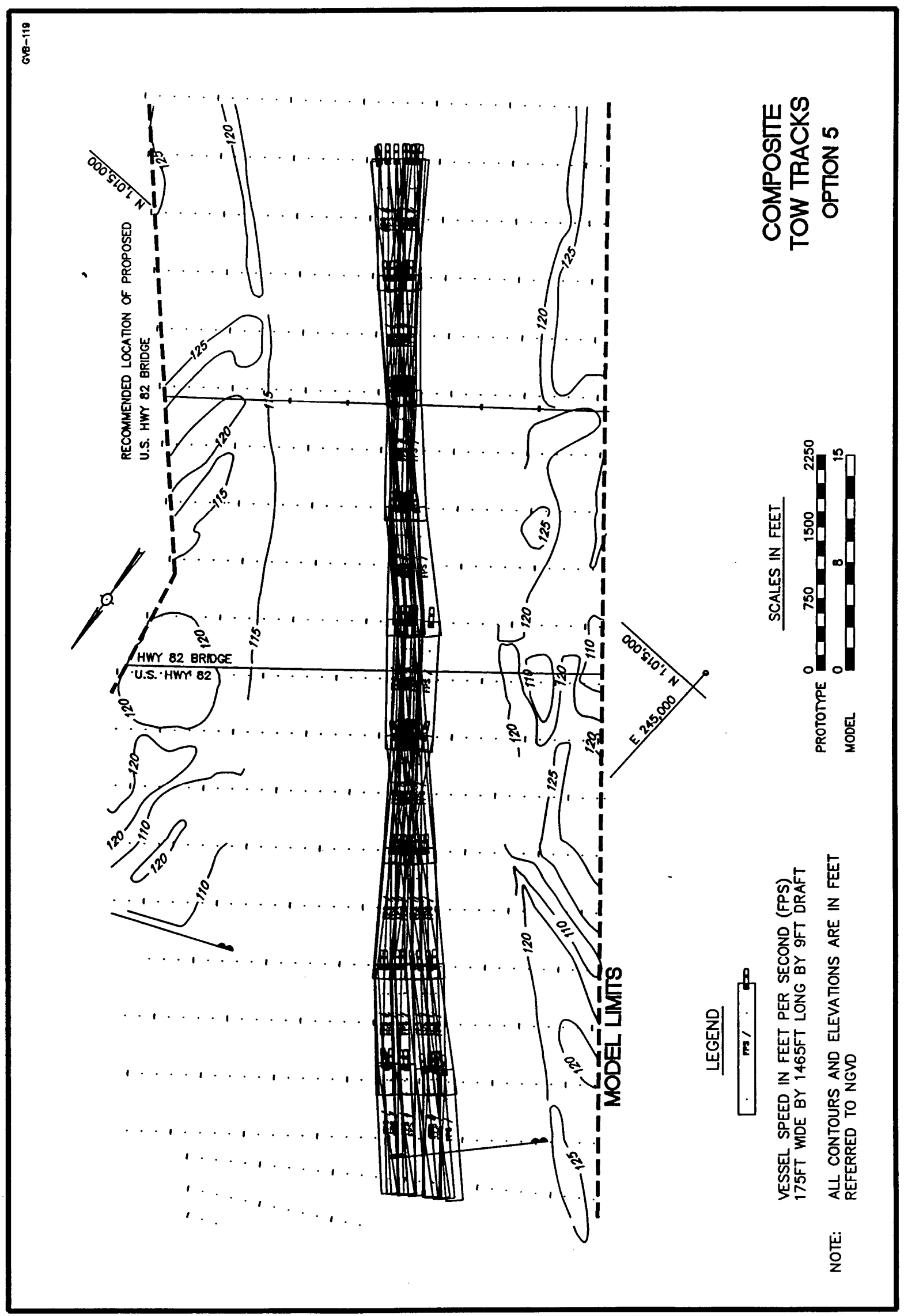




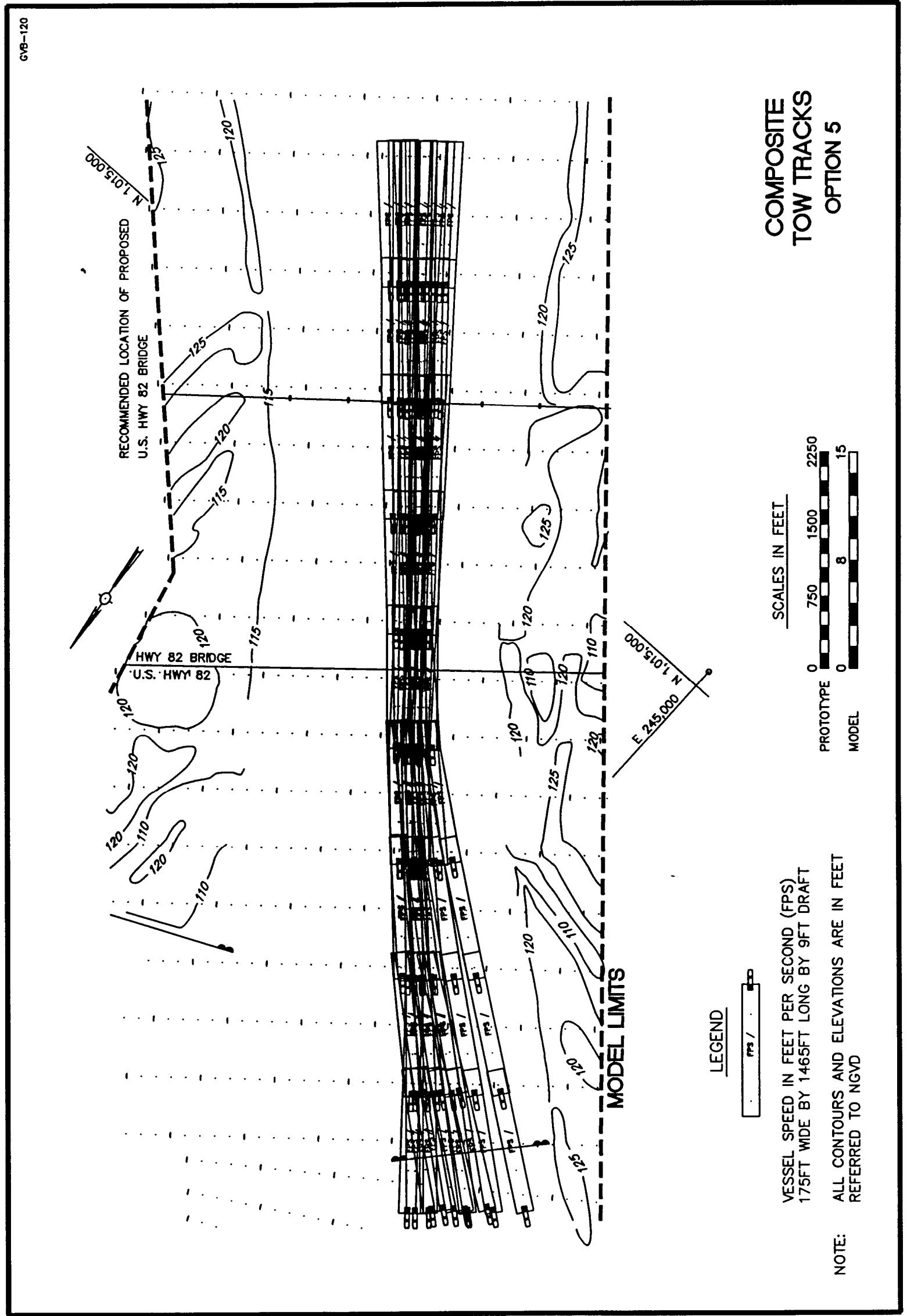

PLATE 48 


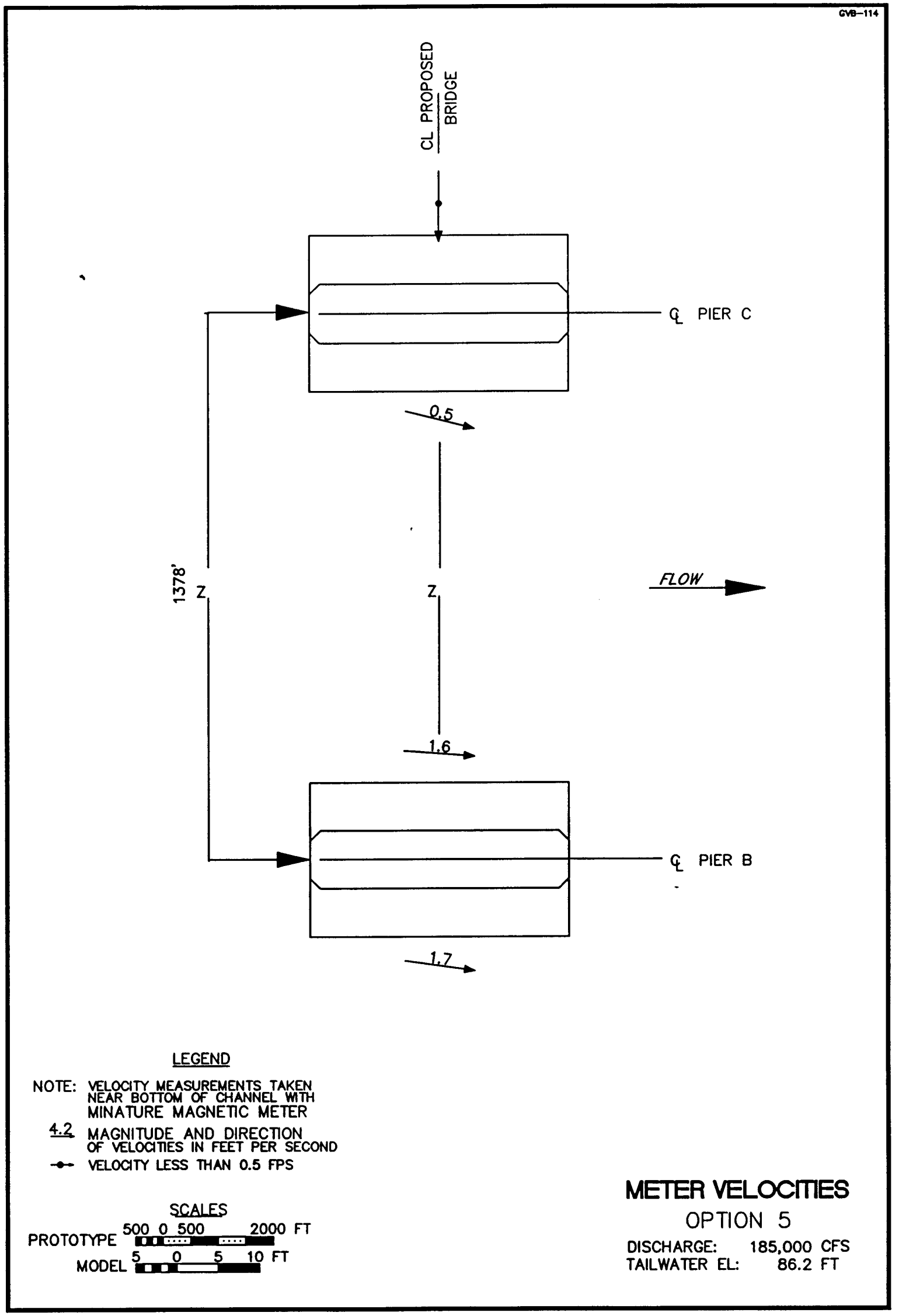

Plate 49 

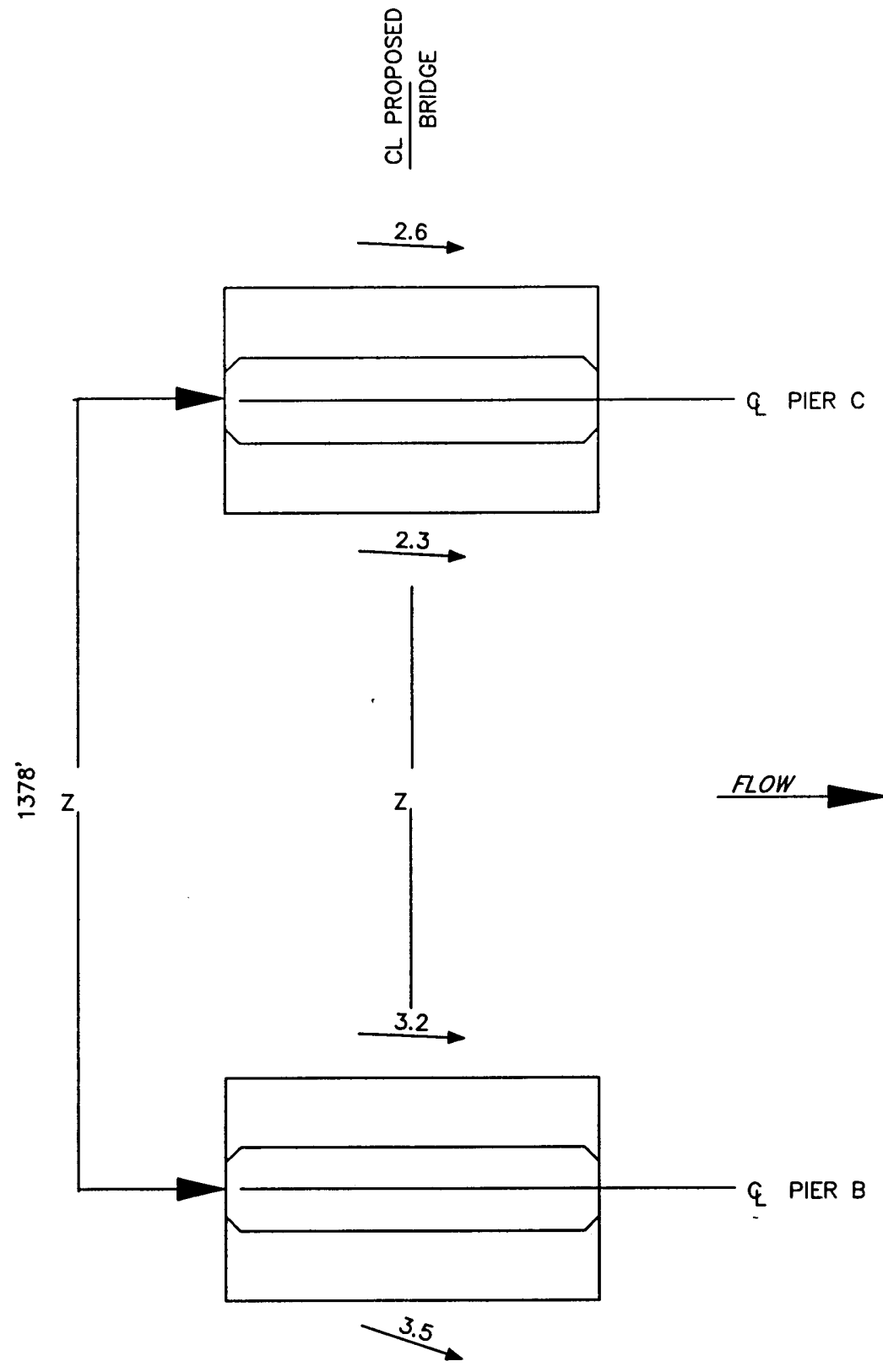

LEGEND

NOTE: VELOCITY MEASUREMENTS TAKEN NEAR BOTTOM OF CHANNEL WTH

MINATURE MAGNETIC METER

4.2 MAGNITUDE AND DIRECTION

OF VELOCITIES IN FEET PER SECOND

- VELOCITY LESS THAN 0.5 FPS

SCALES

PROTOTYPE $500 \quad 0 \quad 500$

$\begin{array}{llll}5 & 0 & 5 & 10\end{array}$

METER VELOCTIES OPTION 5

DISCHARGE: $\quad 395,000$ CFS

TAILWATER EL: $\quad 97.2$ FT

Plate 50 


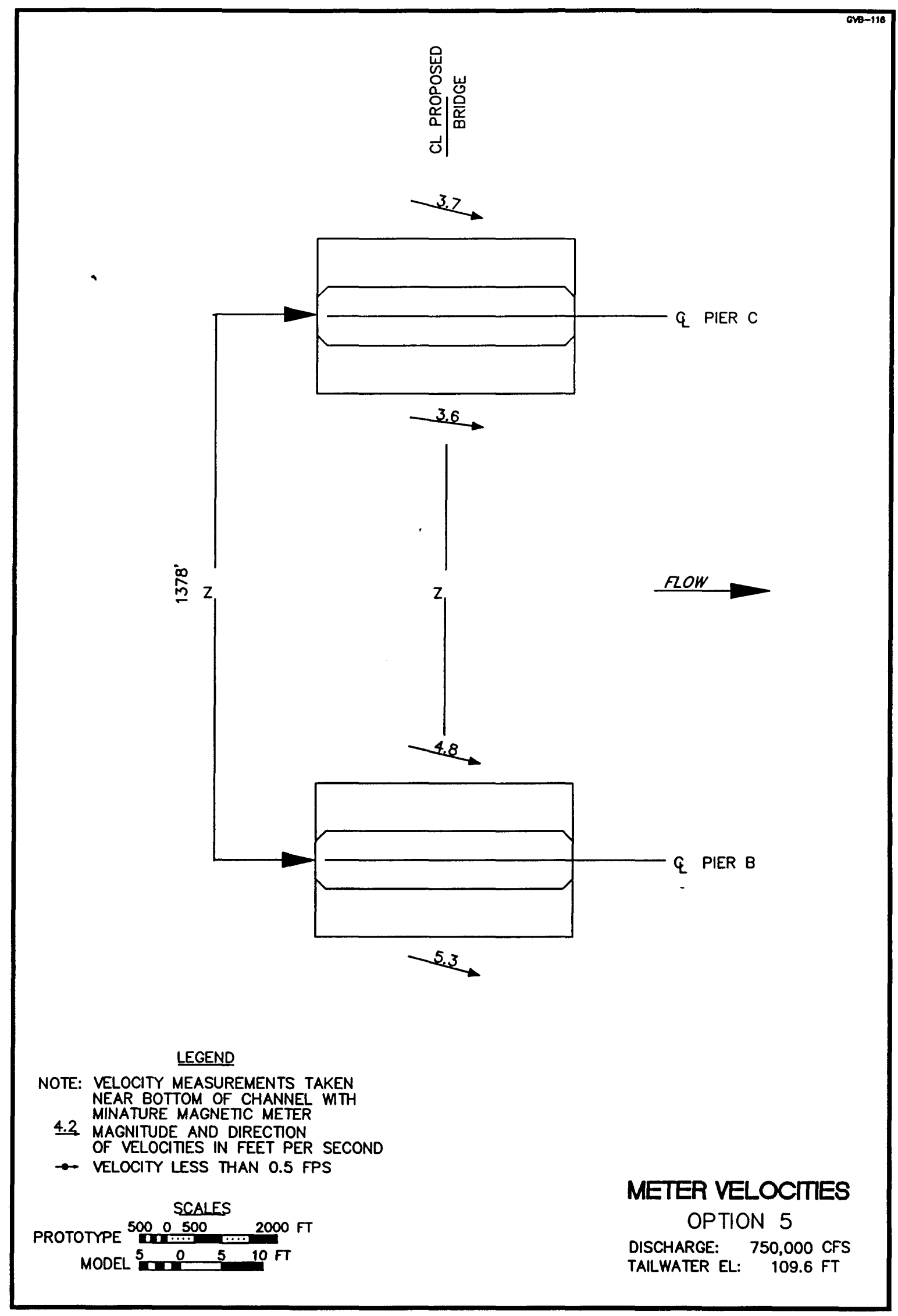

Plate 51 

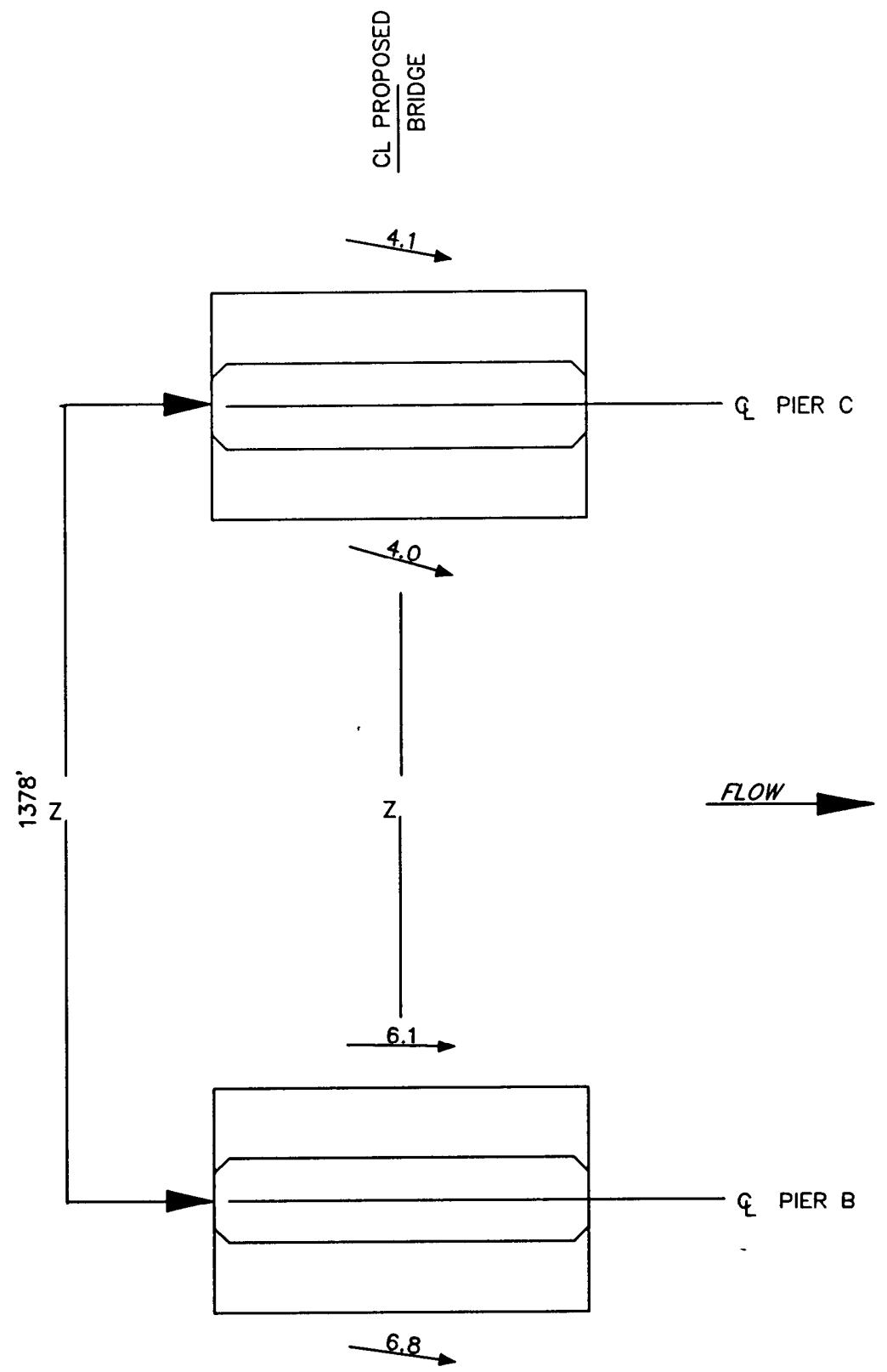

LEGEND

NOTE: VELOCITY MEASUREMENTS TAKEN NEAR BOTTOM OF CHANNEL WITH MINATURE MAGNETIC METER

4.2 MAGNITUDE AND DIRECTION OF VELOCITIES IN FEET PER SECOND

$\rightarrow$ VELOCITY LESS THAN 0.5 FPS

SCALES

PROTOTYPE $500 \quad 0 \quad 500 \quad 2000$ FT

MODEL $5 \quad 0 \quad 5 \quad 10$ FT

METER VELOCITIES OPTION 5

DISCHARGE: $\quad 1,025,000$ CFS

TAILWATER EL: 117.2 FT

Plate 52 

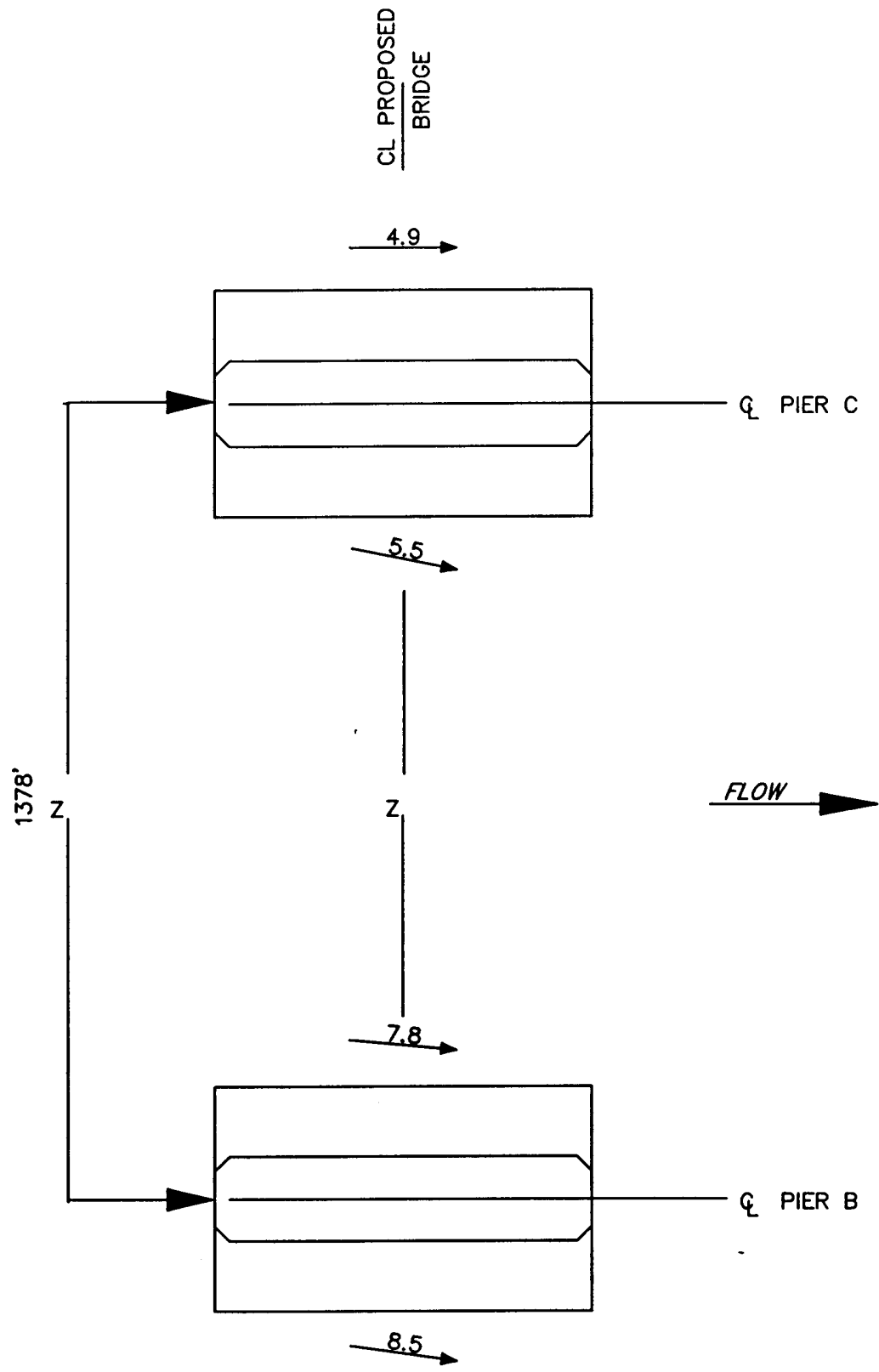

LEGEND

NOTE: VELOCITY MEASUREMENTS TAKEN

NEAR BOTTOM OF CHANNEL WTH

MINATURE MAGNETIC METER

4.2 MAGNITUDE AND DIRECTION

OF VELOCITIES IN FEET PER SECOND

$\rightarrow$ VELOCITY LESS THAN 0.5 FPS

\section{SCALES}

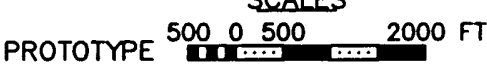

MODEL $5 \quad 0 \quad 5 \quad 10$ FT

METER VELOCITIES OPTION 5

DISCHARGE: $\quad 1,500,000$ CFS

TAILWATER EL: 127.2 FT 


\section{REPORT DOCUMENTATION PAGE}

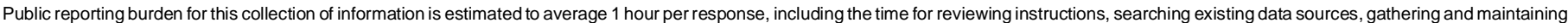

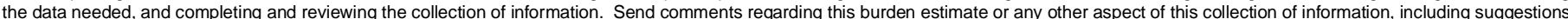

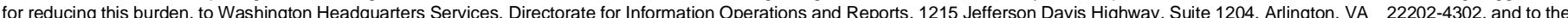
Office of Management and Budget, Paperwork Reduction Project (0704-0188), Washington, DC 20503.

\begin{tabular}{|c|c|c|}
\hline 1. AGENCY USE ONLY (Leave blank) & $\begin{array}{ll}\text { 2. } & \text { REPORT DATE } \\
& \text { September } 2000\end{array}$ & $\begin{array}{l}\text { 3. REPORT TYPE AND DATES COVERED } \\
\text { Final report }\end{array}$ \\
\hline
\end{tabular}

\section{TITLE AND SUBTITLE}

5. FUNDING NUMBERS

Navigation Span Location Study for Greenville Bridge Reach, Mississippi River

6. AUTHOR(S)

Donald C. Wilson

\section{PERFORMING ORGANIZATION NAME(S) AND ADDRESS(ES)}

U.S. Army Engineer Research and Development Center Coastal and Hydraulics Laboratory 3909 Halls Ferry Road, Vicksburg, MS 39180-6199

9. SPONSORING/MONITORING AGENCY NAME(S) AND ADDRESS(ES)

U.S. Army Engineer District, Vicksburg

4155 Clay Street

Vicksburg, MS 39180-3435
8. PERFORMING ORGANIZATION REPORT NUMBER

ERDC/CHL TR-00-20

\section{SUPPLEMENTARY NOTES}

12a. DISTRIBUTION/AVAILABILITY STATEMENT

12b. DISTRIBUTION CODE

Approved for public release; distribution is unlimited.

13. ABSTRACT (Maximum 200 words)

Navigation conditions through the existing U.S. Highway 82 bridge at Greenville, MS, are difficult and hazardous because of the alignment and velocities of the currents approaching the bridge. The U.S. Army Engineer District, Vicksburg, used physical hydraulic models to develop a channel realignment to improve navigation through the bridge. After construction of the channel realignment was underway, the Mississippi Department of Transportation advised the U.S. Army Corps of Engineers that a new bridge was proposed at Greenville. The existing 1:150 scale semifixed bed model of Greenville Bridge Reach was used to determine if the proposed navigation span was properly located and to the necessary width. A modified design was recommended based on these model results.

\section{SUBJECT TERMS}

Bridges (Greenville)

Hydraulic model

Mississippi River
Navigation conditions

Semifixed bed
15. NUMBER OF PAGES

78

16. PRICE CODE

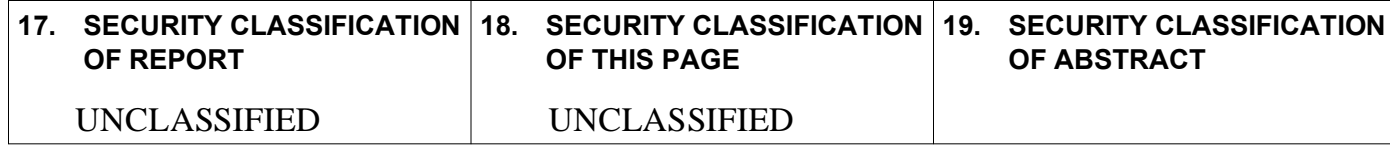

NSN 7540-01-280-5500
Standard Form 298 (Rev. 2-89) Prescribed by ANSI Std. Z39-18 298-102 
Destroy this report when no longer needed. Do not return it to the originator. 